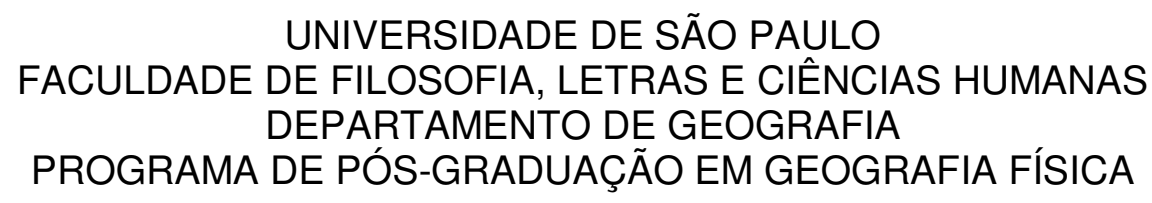

Fernanda Volpon Neves

ANÁLISE MORFOLÓGICA DA EVOLUÇÃO DA CAPTURA DO RIO GUARATUBA (BERTIOGA - SP) ATRAVÉS DA TÉCNICA DE DATAÇÃO POR LUMINESCÊNCIA OPTICAMENTE ESTIMULADA (LOE)

(VERSÃO CORRIGIDA)

São Paulo

2012 
UNIVERSIDADE DE SÃO PAULO

FACULDADE DE FILOSOFIA, LETRAS E CIÊNCIAS HUMANAS

DEPARTAMENTO DE GEOGRAFIA

PROGRAMA DE PÓS-GRADUAÇÃO EM GEOGRAFIA FÍSICA

Fernanda Volpon Neves

\section{ANÁLISE MORFOLÓGICA DA EVOLUÇÃO DA CAPTURA DO RIO GUARATUBA (BERTIOGA - SP) ATRAVÉS DA TÉCNICA DE DATAÇÃO POR LUMINESCÊNCIA OPTICAMENTE ESTIMULADA (LOE)}

Dissertação apresentada ao Programa de Pós-Graduação em Geografia Física da Faculdade de Filosofia, Letras e Ciências Humanas da Universidade de São Paulo para obtenção do título de Mestre.

Orientadora: $\operatorname{Prof}^{\mathrm{a}} \mathrm{Dr}^{\mathrm{a}}$ Déborah de Oliveira Área de Concentração: Geografia Física

São Paulo

2012 


\section{FICHA CATALOGRÁFICA}

Catalogação na Publicação

Serviço de Biblioteca e Documentação

Faculdade de Filosofia, Letras e Ciências Humanas da Universidade de São Paulo.

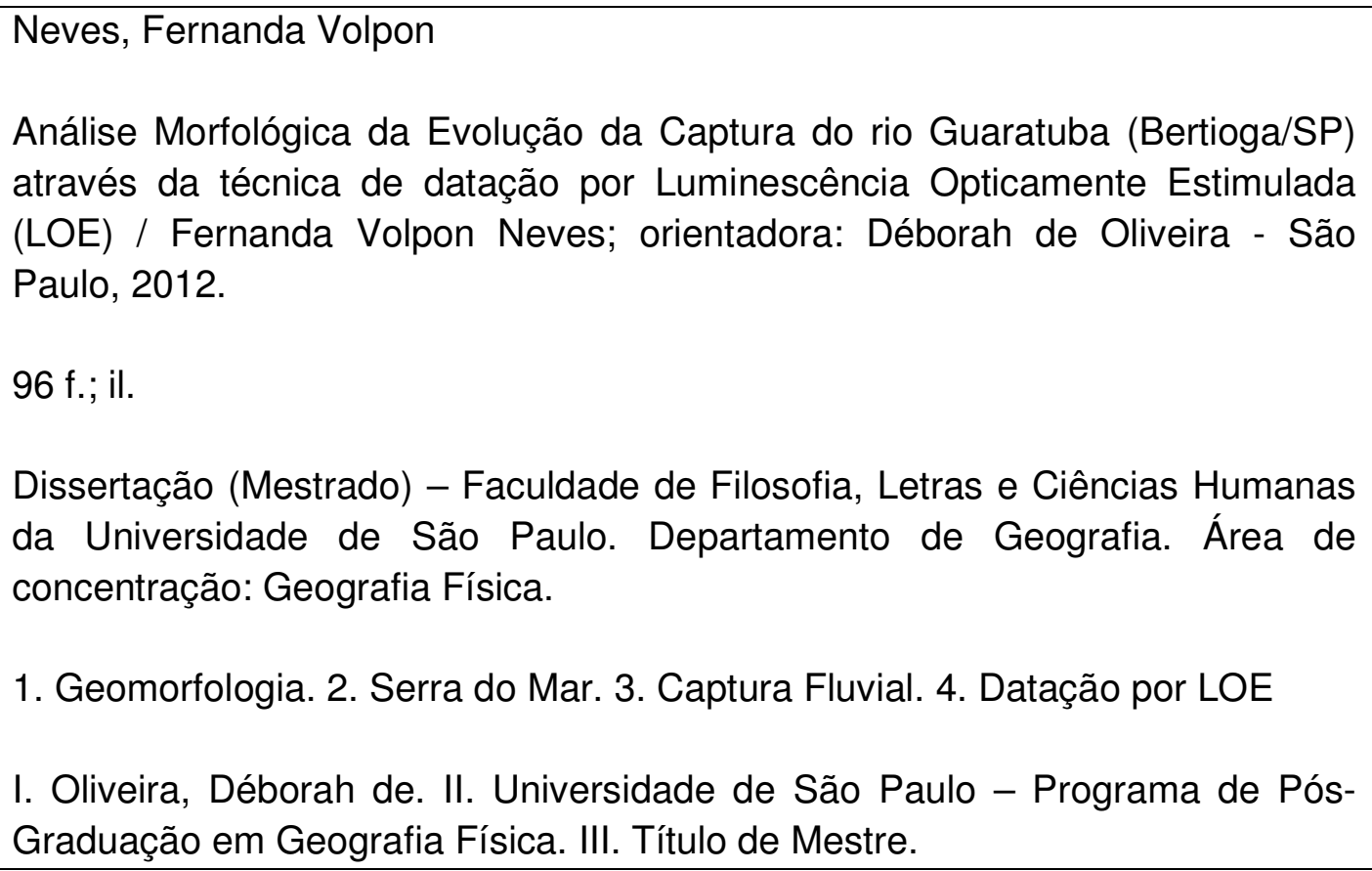

I. Oliveira, Déborah de. II. Universidade de São Paulo - Programa de PósGraduação em Geografia Física. III. Título de Mestre. 
Fernanda Volpon Neves

\section{Análise Morfológica da Evolução da Captura do rio Guaratuba (Bertioga/SP) através da técnica de datação por Luminescência Opticamente Estimulada (LOE)}

Dissertação apresentada ao Programa de Pós-Graduação em Geografia Física da Faculdade de Filosofia, Letras e Ciências Humanas da Universidade de São Paulo para obtenção do título de Mestre.

\section{Banca Examinadora}

\section{Prof $^{a}$ Dr $^{\mathrm{a}}$ Déborah de Oliveira}

Departamento de Geografia - Universidade de São Paulo

Prof Dr. Adilson Avasi de Abreu

Departamento de Geografia - Universidade de São Paulo

Prof. Dr. Archimedes Perez Filho

Departamento de Geografia - Universidade Estadual de Campinas

São Paulo

2012 
Aos meus pais, Pedro e Lurdinha, que me apoiaram incondicionalmente. 


\section{AGRADECIMENTOS}

Agradecimento especial à minha orientadora, Déborah de Oliveira, por sua orientação e apoio nesta pesquisa, pela oportunidade de me proporcionar este mestrado, Obrigado.

Ao Programa de Pós-Graduação em Geografia Física da FFLCHUSP, pela oportunidade de me aprimorar e crescer.

Aos meus queridos pais, que sempre me apoiaram e incentivaram com as palavras certas! Aos meus irmãos, em especial Arthur que dividiu o espaço de estudo comigo, pegou livros na USP diversas vezes, e ajudou na construção desta pesquisa sempre com palavras de incentivo!

A minha família, tios (as), primos (as) e minha linda avó Lurdes. Ao meu lindo sobrinho Rico, que veio alegrar ainda mais a vida de nossa família.

Aos meus amigos de Araçatuba, Campinas, São Paulo... mesmo longe, tão perto de meus pensamentos.

Aos meus amigos e colegas da ARCADIS Logos, em especial Sandra Favorito, que sempre me apoio e me incentivou nesta pesquisa, me dando oportunidade de me ausentar em diversos momentos. Agradeço à diretoria da Divisão de Meio Ambiente que também proporcionou esta pesquisa.

Aos colegas de mestrado que dividiram a sala de aula, os campos e as aflições dessa dissertação, dividindo muitos cafezinhos, textos, incertezas, dúvidas, em especial à Carol (Maria Carolina Villaça Gomes). Aos colegas que colaboraram nas atividades de campo e coleta de material, Katiucia de Sousa Silva, Natália Nunes de Oliveira, Rogério Leandro de Araújo, Vaniza Pasa. 
Aos funcionários da Secretaria de Pós-Graduação do Departamento de Geografia da FFLCH, sempre muito prestativos.

À equipe do MZUSP que cuidam da Estação Biológica da Boracéia (EBB), em especial Sra. Mercedes Águido da Silva que sempre me auxiliou para conseguir autorização para entrada na EBB para realização da pesquisa.

À FATEC, em especial Profạ. Dra. Sônia Hatsue Tatumi que me cedeu tempo e espaço nos laboratórios de Vidro e Datação para desenvolver as minhas atividades.

Meu agradecimento muito mais que especial à René Rojas Rocca, doutorando em física, pesquisador no LACIFID (Laboratório de Cristais lônicos, filmes finos e datação) no Instituto de Física da USP (IFUSP), através dele foi possível o desenvolvimento da pesquisa, ele quem me auxiliou em todo o processo de datação, pacientemente explicando tudo, os protocolos e como encontrar os resultados nas amostras.

Aos Profs. Adilson Avansi de Abreu e Célia Regina de Gouveia e Souza, por todas as contribuições na banca de qualificação, as quais contribuíram em muito para esta pesquisa. 


\section{RESUMO}

A Serra do Mar pertence ao complexo litorâneo brasileiro, preenchendo todo o litoral desde Santa Catarina até o Rio de Janeiro. As feições de seu relevo são peculiares, resultantes de um tectonismo recente com acelerado processo de intemperismo, que acarreta em feições distintas ao longo de todo o complexo da Serra do Mar. A evolução deste relevo tem como fator resultante a adequação da drenagem às falhas e rupturas presentes nas rochas. Desta forma a evolução da Serra do Mar e compreensão das anomalias de drenagem, tal como a Captura Fluvial do alto rio Guaratuba, passa a ser ponto de investigação desta pesquisa, utilizando datação por Luminescência Opticamente Estimulada (LOE). Para o desenvolvimento da pesquisa foi proposta uma divisão do relevo em três compartimentos geomorfológicos (Planalto, Planície do alto rio Guaratuba, Bordas e escarpa da Serra). A compartimentação foi elaborada respeitando as morfologias e a drenagem local, baseada na teoria de Ab'Saber (1969) sobre a forma de se estudar o Quaternário. Foram elaboradas cartas temáticas (declividade, hipsometria, orientação das vertentes, etc.) para um embasamento visual da teoria discutida no trabalho, vinculando a elas os pontos de coleta das amostras. A partir da compartimentação do relevo desenvolveu-se atividade de campo para coleta de material sedimentar de possíveis trechos do antigo leito fluvial. As amostras coletadas foram trabalhadas em laboratório por datação através da técnica de LOE, utilizando-se o protocolo de alíquota única (SAR). As amostras foram trabalhadas quimicamente para que se obtivesse o grão de quartzo na sua forma mais pura. A partir dos dados adquiridos através da 
datação, as informações foram trabalhadas em planilhas e softwares voltados para a interpretação dos dados. Os valores alcançados foram discutidos ao longo da pesquisa, justificando-se os apontamentos positivos e negativos das amostras. Os dados obtidos concordam com a literatura abordada sobre a evolução geomorfológica da Serra do Mar.

Palavras-chave: Serra do Mar, Compartimentação Geomorfológica, Captura Fluvial do Rio Guaratuba, Datação por LOE (OSL). 


\begin{abstract}
The Serra do Mar mountain range belongs to the Brazilian coastal complex which runs from the state of Santa Catarina to Rio de Janeiro. Its relief has peculiar features, derived from a recent tectonism with accelerated weathering process, which leads to distinct features throughout the complex of the Serra do Mar. The evolution of this relief results in the drainage adequacy to the failures and disruptions found in the rocks. Therefore, the evolution of the Serra do Mar and understanding of drainage anomalies, such as the Guaratuba upper river fluvial capture, becomes the point of investigation in this research, using Optically Stimulated Luminescence (OSL) for dating. For the development of the research, the relief was divided into three geomorphologic compartments (Plateau, Guaratuba upper river plain, Borders and Scarp of the Serra do Mar). The compartmentation was developed in compliance with the morphologies and local drainage, based on the Ab'Saber Theory (1969) on how to study the Quaternary. Thematic maps were drawn (slope, hypsometry, orientation of the strands, etc.) for a visual basis of the theory discussed in the thesis, linking them to the points of sample collection. From the relief compartmentation a field activity was carried out for the collection of sedimentary material of possible sections of the old riverbed. The samples were processed in the laboratory through the technique of dating OSL, using the single-aliquot regenerative-dose (SAR). Samples were chemically worked out to obtain the quartz grain in its pure form. From the data acquired through dating, the information was analyzed on spreadsheets and software focused on the interpretation of data. The values achieved were discussed throughout the thesis research to explain any positive
\end{abstract}


and negative results of the samples. The data obtained agree with the literature on the geomorphological evolution of the Serra do Mar that is presented in the thesis.

Keywords: Serra do Mar, Geomorphological compartmentation, Guaratuba River Fluvial Capture, OSL Dating. 


\section{LISTA DE FIGURAS}

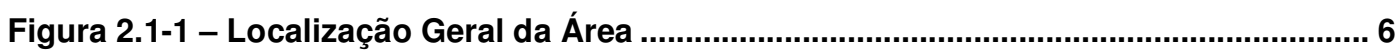

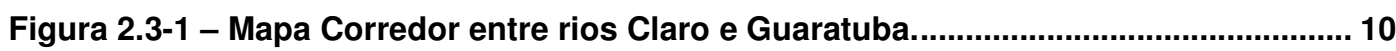

Figura 2.3-2 - Mapa dos exemplos de padrão de drenagem representativos para a área de

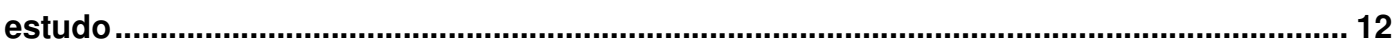

Figura 3.1-1 - Modelos de evolução da bacia do alto Guaratuba...................................... 22

Figura 4.1-1 - Fluxograma das etapas metodológicas e dos materiais .............................. 36

Figura 4.2-1 - Mapa de Localização dos pontos de coleta. .................................................. 44

Figura 4.2-2 - Esquema do tubo de coleta de campo e a divisão do material coletado. ... 58

Figura 4.2-3 - Tabela com os dados de localização da amostra e as medidas de massa da

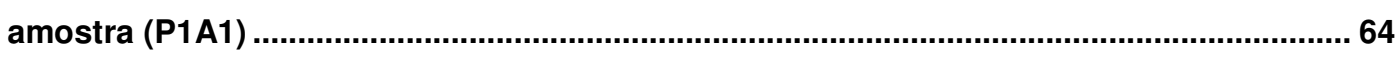

Figura 4.2-4 - Exemplo da utilização dos valores obtidos pela dose anual ......................... 69

Figura 4.2-5 - Tabela extraída do Sequence Editor ......................................................... 72

Figura 4.2-6 - Informações extraídas do software RISO-Analyst para a amostra P1A1 .... 73

Figura 5.3-1 - Gráfico dos dados da amostra P3A2 ............................................................ 87

\section{LISTA DE TABELAS}

Tabela 4.2-1 - Horizontes de solo do ponto de coleta 1 ........................................................ 49

Tabela 4.2-2 - Horizontes de solo do ponto de coleta 2 ................................................ 50

Tabela 4.2-3 - Horizontes de solo do ponto de coleta 3 ..................................................... 52

Tabela 4.2-4 - Tabela com os dados dos elementos componentes da dose anual de todas

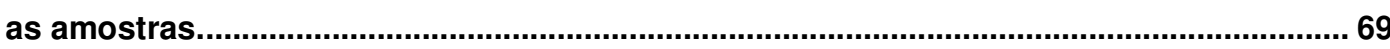

Tabela 4.2-5 - Conversão dos dados extraídos do leitor RISO em Gray, para cálculo da

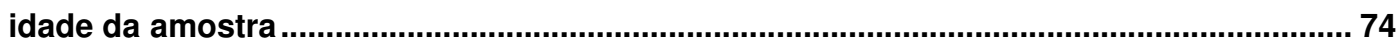

Tabela 5.3-1 - Idade das amostras realizadas em LOE........................................................ 84

\section{LISTA QUADROS}

Quadro 5.2-1 - Pontos de Coleta de amostras para as datações.

\section{LISTA DE GRÁFICOS}

Gráfico 4.2-1 - Perda de umidade das amostras.

Gráfico 4.2-2 - Comportamento médio da amostra P1A2 em resposta ao estímulo luminescente na Daybreak 
Gráfico 4.2-3 - Cálculo médio do sinal das amostras por estímulo luminescente na Daybreak

\section{LISTA DE FOTOS}

Foto 2.2-1 - Vegetação ao longo do Cotovelo. 8

Foto 2.2-2 - Vista do rio Guaratuba e sua vegetação à montante da captação de água pela adutora.

Foto 4.2-1 - Material utilizado na coleta. 46

Foto 4.2-2 - Inserindo tubo de alumínio na trincheira para coleta do material. .................... 46

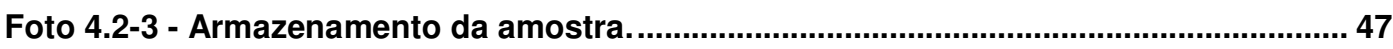

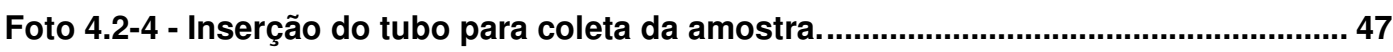

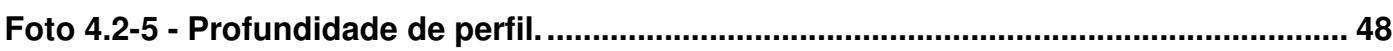

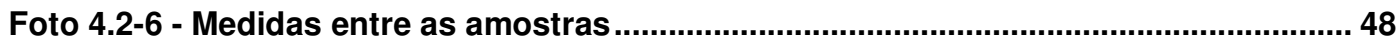

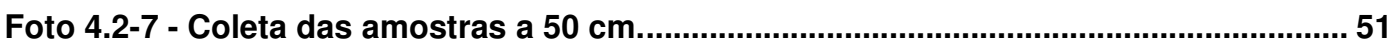

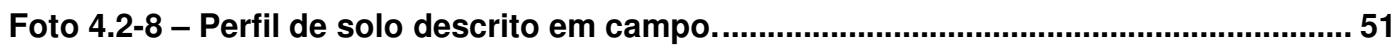

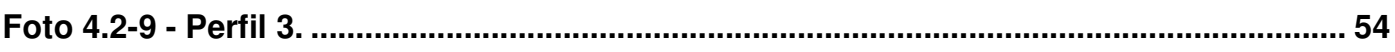

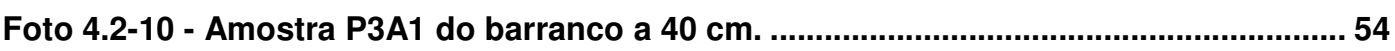

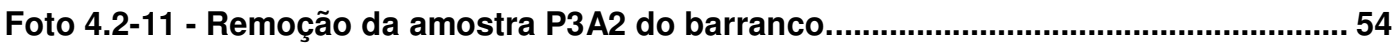

Foto 4.2-12 - Cascalheira encontrada no barranco........................................................... 54

Foto 4.2-13 - Alguns materiais utilizados para selecionar e organizar as amostras na

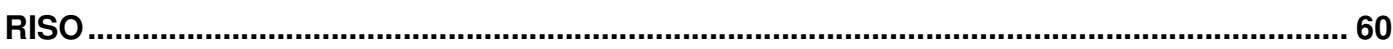

Foto 4.2-14 - Material preparado para dose equivalente e dosagem ambiental .................60 60

Foto 4.2-15 - Capela para manuseio dos produtos químicos. Ao fundo à direita máquina

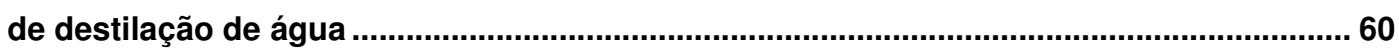

Foto 4.2-16 - Máquina RISO (à direita) Medidor de radiação (à esquerda da foto)...............60

Foto 4.2-17 - Separação do material para teste na TL........................................................... 66

Foto 4.2-18 - Prato onde se coloca a amostra para teste na TL e na LOE. ........................ 66

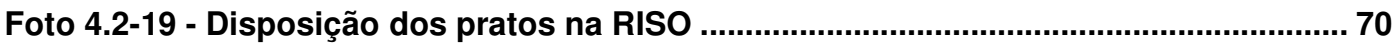

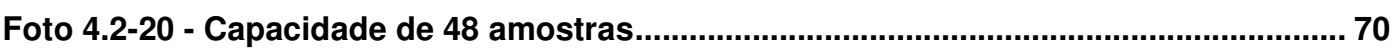

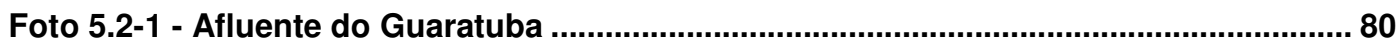

Foto 5.2-2 - Bandamento no fundo do rio, transversal a drenagem ................................... 80

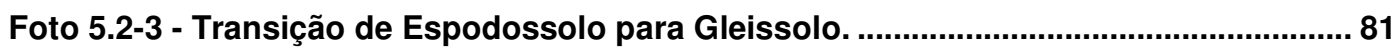

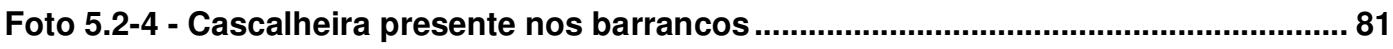

Foto 5.2-5 - Orientação das rochas NE-SW, Guaratuba correndo oblíquo às estruturas.. 82

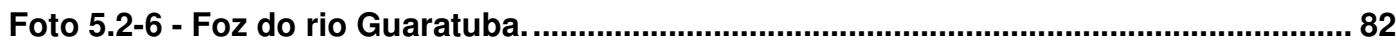

Foto 5.2-7 - Estrada de acesso à Casa de captação de água. .............................................. 83

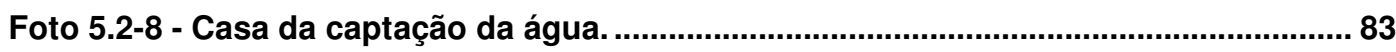




\section{SUMÁRIO}

1. INTRODUÇÃO, OBJETIVOS E JUSTIFICATIVA. ....................................... 1

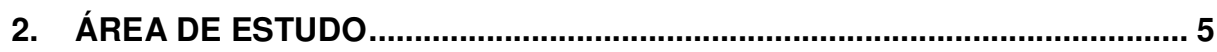

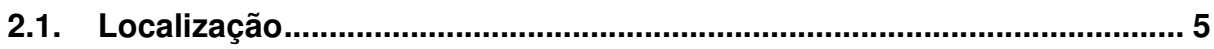

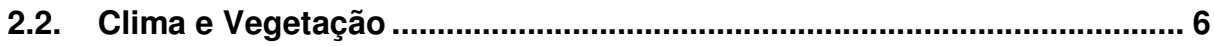

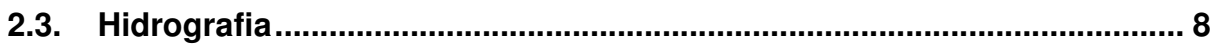

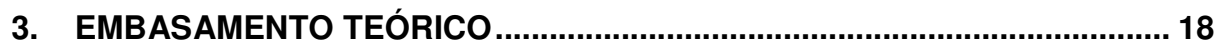

3.1. Rede Hidrográfica e Captura Fluvial...................................................... 18

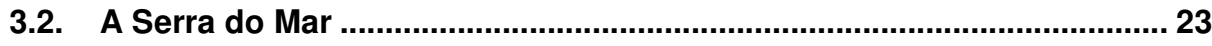

3.3. Datação de material sedimentar............................................................ 30

4. MÉTODOS, TÉCNICAS E PROCEDIMENTOS GERAIS .............................. 34

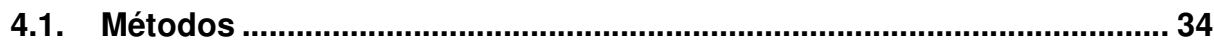

4.2. Técnicas e Procedimentos Gerais ….................................................... 37

4.2.1. Levantamento e pesquisa bibliográfica ...............................................37

4.2.2. Fontes cartográficas e vetorização........................................................ 37

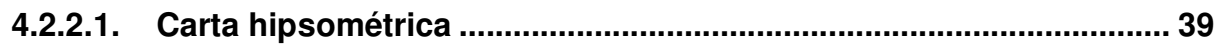

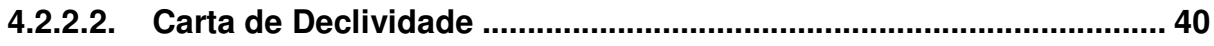

4.2.2.3. Carta de Orientação das vertentes. .................................................... 41

4.2.2.4. Carta de Drenagem da área ................................................................ 41

4.2.2.5. Carta de compartimentação do relevo .............................................. 41

4.2.3. Trabalho de campo e seleção dos pontos de coleta ........................... 42

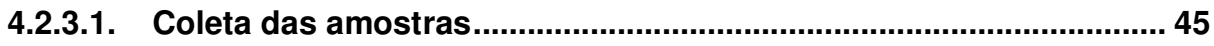

4.2.3.2. Pontos de coleta e descrição das amostras ...................................... 47

4.2.4. Luminescência oticamente estimulada (LOE) .................................... 55

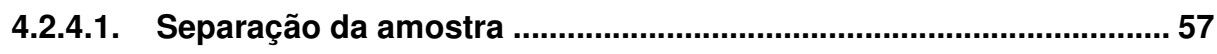

4.2.4.2. Desenvolvimento em laboratório ..................................................... 59 


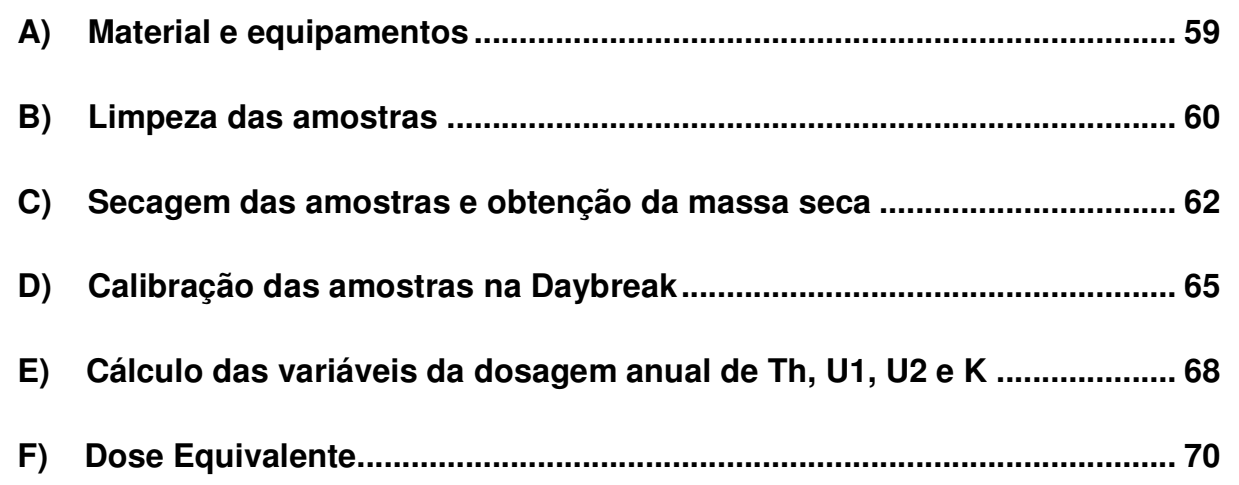

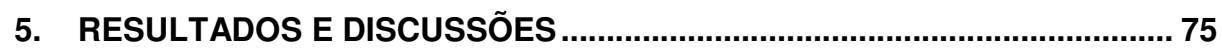

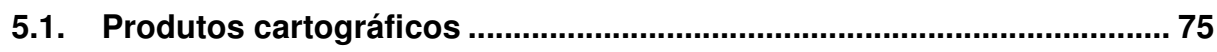

5.1.1. Carta Hipsométrica (ANEXO A) ....................................................... 75

5.1.2. Carta de Declividade (ANEXO B)........................................................... 76

5.1.3. Carta de Orientação das Vertentes (ANEXO C) .................................. 77

5.1.4. Carta de Drenagem da área (ANEXO D) .......................................... 77

5.1.5. Compartimentação do Relevo (ANEXO E) .........................................78

5.2. Relação do material coletado com a evolução do relevo.......................78

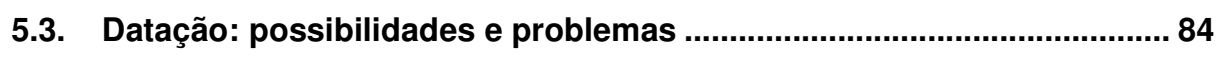

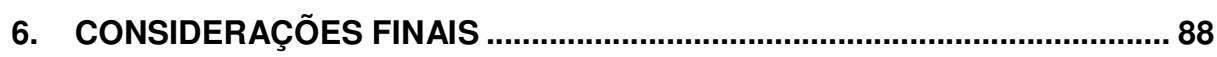

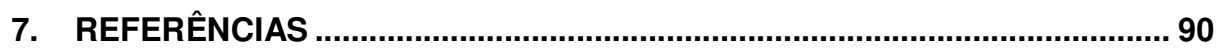

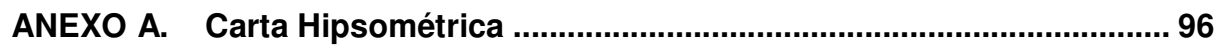

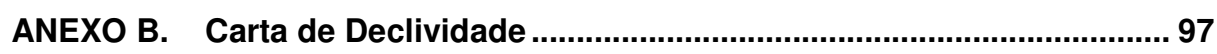

ANEXO C. Carta de Orientação das Vertentes ............................................. 98

ANEXO D. Carta de Drenagem da area .......................................................... 99

ANEXO E. Carta de Compartimentação Geomorfológica............................ 100 


\section{INTRODUÇÃO, OBJETIVOS E JUSTIFICATIVA.}

Pertencente ao complexo litorâneo que compreende desde Santa Catarina até o Rio de Janeiro, onde se observam feições peculiares com diversas formas e desníveis cristalinos, resultantes de um tectonismo recente e com acelerado processo de intemperismo que acarreta em feições muito distintas numa mesma área ou bacia, a Serra do Mar preenche toda a extensão do litoral paulista.

Dentre os pontos conhecidos como peculiares, destaca-se o trecho do reverso da Serra do Mar, próximo a Salesópolis, mais precisamente no reverso da serra de Guaratuba, na cidade de Bertioga. Estes pontos, assim como praticamente todo litoral paulista, refletem os condicionamentos geológicos que delimitam e demarcam a região de planalto (no interior da serra) com feições suaves, áreas de serras escarpadas, por vezes abruptas, além da planície litorânea.

As diversidades fitofisionômicas da área são principalmente reforçadas pelos diversos compartimentos naturais que a Serra do Mar apresenta, influenciados em sua maioria pelas diferenças de temperatura, relevo, altitude, precipitação. $\mathrm{Na}$ área da pesquisa tem por vegetação predominante a Mata Atlântica com vegetação primária, sendo distinguida em diferentes níveis por diferenças de relevo planalto/ escarpa/ planície e assim sucessivamente.

Neste contexto de diversificação e compartimentação geomorfopedológica e climática que irão se desenvolver as discussões acerca das alterações de percurso do rio Guaratuba. Uma análise da compartimentação do local possibilitará a compreensão dos fenômenos que provocaram estas mudanças nas feições morfológicas da área. 
O rio Guaratuba teve seu leito redirecionado e ainda passa por processos de transformações. O padrão no qual o curso do rio está enquadrado, devido às alterações de suas feições, é conhecido como Captura Fluvial ou River Piracy. A pesquisa se desenvolverá nesse contexto de captura fluvial, correlacionando os aspectos físicos do relevo e as características empíricas de evolução da Serra do Mar.

A área estudada é um local onde há estudos sobre os elementos do meio físico, assim como estrutural. A pesquisa busca fornecer informações sobre os elementos que compõem a paisagem, visando melhor conhecer e estabelecer relações entre a morfologia local e a geologia da área. Assim, na procura por essas relações diretas ou indiretas, parte-se de discussões considerando que a área sofreu alguma alteração estrutural para que o rio Guaratuba alterasse seu curso, mudando o seu trajeto inicial, que corria para o interior do Estado de São Paulo, passando a desaguar no litoral paulista. A alteração do traçado do rio é recente quando se considera períodos geológicos e não podendo considerar apenas os processos erosivos e de recuo de cabeceiras do rio como modeladores da paisagem local.

Desse modo, nessa área de difícil acesso, na qual as diferenciações entre drenagem, vegetação e declividade, objetivou-se caracterizar e identificar as áreas que poderiam ser testemunhos de alterações e mudanças climáticas, assim como trechos de deposição de material em que em um único pacote de solo, ou num conjunto deles, fosse possível identificar a história local.

Visando o estudo das relações existentes entre as alterações da drenagem e o modelado do relevo através de análises morfológicas, as reflexões acerca do objeto do trabalho têm como base inicial os trabalhos de pesquisa de Rossi (1999) e Oliveira (2003). Por conseguinte, faz-se uma análise morfológica do 
quadrante compreendido pela captura fluvial, analisando formas e vestígios, como as cascalheiras apresentadas por Rossi (1999) e Oliveira (2003), utilizando técnicas de datação de Luminescência opticamente estimulada (LOE).

Rossi (1999) identificou a captura fluvial do rio Guaratuba e desenvolveu sua pesquisa acerca dos círculos concêntricos para classificação da drenagem local. Oliveira (2003) utilizou a área já identificada por ROSSI como potencial local de vestígios da captura e trabalhou a pedogênese da área intensificando as justificativas e os modelos de evolução da vertente, em que defende, o recuo de cabeceiras como potencializador da evolução da vertente local e da captura fluvial. $\mathrm{Na}$ pesquisa que será desenvolvida, parte-se do pressuposto que a drenagem e o relevo sofreram alterações por basculamento e ajustes constantes na Serra do Mar.

O rio Guaratuba tem suas nascentes no planalto interno da serra do Mar, próximo à represa Ribeirão do Campo, e corre sentido ENE-SW até as escarpas da serra desaguando no litoral. O rio Guaratuba conserva seu cotovelo bem demarcado da captura ao longo de uma extensão de mais de 300 metros. Os desníveis encontrados na área de pesquisa variam de 1100 metros no topo da área escarpada e partes do planalto interno, até o nível do mar (não pertencente à área da pesquisa).

A área de estudo não está delimitada em formato de bacia de drenagem, mas focada no quadrante que engloba o cotovelo da Captura de drenagem do rio Guaratuba e as áreas de entorno próximas.

Considerando a evolução da Serra do Mar e a Captura Fluvial do rio Guaratuba, bem como a importância por compreender os períodos geológicos nos quais o fenômeno ocorreu, a presente pesquisa tem por objetivo principal analisar a evolução da Serra do Mar, mais especificamente o cotovelo de captura do rio 
Guaratuba, identificando os compartimentos geomorfológicos e analisando-os através de Datação de quartzo por LOE (Luminescência Opticamente Estimulada). Contudo serão necessários os seguintes objetivos específicos:

a) Selecionar dentro da bacia do Guaratuba os trechos mais representativos para a compreensão da evolução do relevo;

b) Compartimentar a área a fim de identificar os pontos principais para a análise técnica;

c) Datar material coletado em campo, para determinar a idade do período que a captura fluvial possa ter ocorrido;

d) Compreender a partir dos resultados obtidos, com análise por LOE, a evolução que se deu no trecho compreendido pelo cotovelo de captura do rio Guaratuba.

A compreensão da evolução da Serra do Mar no ponto da captura fluvial, assim como as datações por LOE tem as seguintes justificativas:

- Contribuição para o entendimento do período no qual a captura fluvial ocorreu;

- O provável trecho da captura fluvial pode ser a chave para a compreensão do período de evolução da Serra do Mar

- A datação por LOE é a técnica mais indicada para datar as amostras de quartzo encontradas - testemunhos dos depósitos fluviais do rio Guaratuba. 


\section{2. ÁREA DE ESTUDO}

\subsection{Localização}

A área de estudo localiza-se no reverso da Serra do Mar, no município de Bertioga (Figura 2.1-1), próximo à Estação Biológica da Boracéia ${ }^{1}$ (EBB). A área de pesquisa está situada no quadrante entre as coordenadas UTM X: 405000 / X: 411000 e Y: 7385000/ Y: 7379000. Delimitou-se este quadrante como sendo o principal trecho a ser apresentado nos mapas para as discussões acerca do material localizado no reverso da Serra do Mar.

A área está compreendida nos limites municipais de Salesópolis, Biritiba Mirim e Bertioga. As principais rodovias de acesso à região a partir de São Paulo são SP-070 e SP-088. A partir da Marginal Tietê segue via Rodovia Ayrton Senna da Silva e Rodovia dos Trabalhadores, sentido Mogi das Cruzes. Ao chegar a Mogi das Cruzes seguir pela rodovia Alfredo Rolim de Moura, logo após passar pela cidade de Biritiba Mirim entrar à direita na estrada da Casa Grande sentido estação da Sabesp

e Estação Biológica da Boracéia, por volta das coordenadas UTM X: 396185/ Y: 7393360.

Nos trabalhos de Rossi (1999) e Oliveira (2003), é destacada a presença de uma grande cascalheira à NW da área de estudo. Uma vez descrita a cascalheira como testemunho de um provável terraço fluvial abandonado, formado a partir das diversas capturas fluviais que o rio Guaratuba sofreu, considera-se que a datação do

1 A estação Biológica da Boracéia faz parte do complexo do Parque Estadual da Serra do Mar, está inserida dentro de uma estação de captação de águas da Sabesp, sendo a EBB controlada pela equipe do MZUSP (Museu de Zoologia da USP). 
material contido nesses pacotes de depósitos, poderá indicar algo como períodos geológicos ou até mesmo o período da própria captura fluvial.

Figura 2.1-1 - Localização Geral da Área

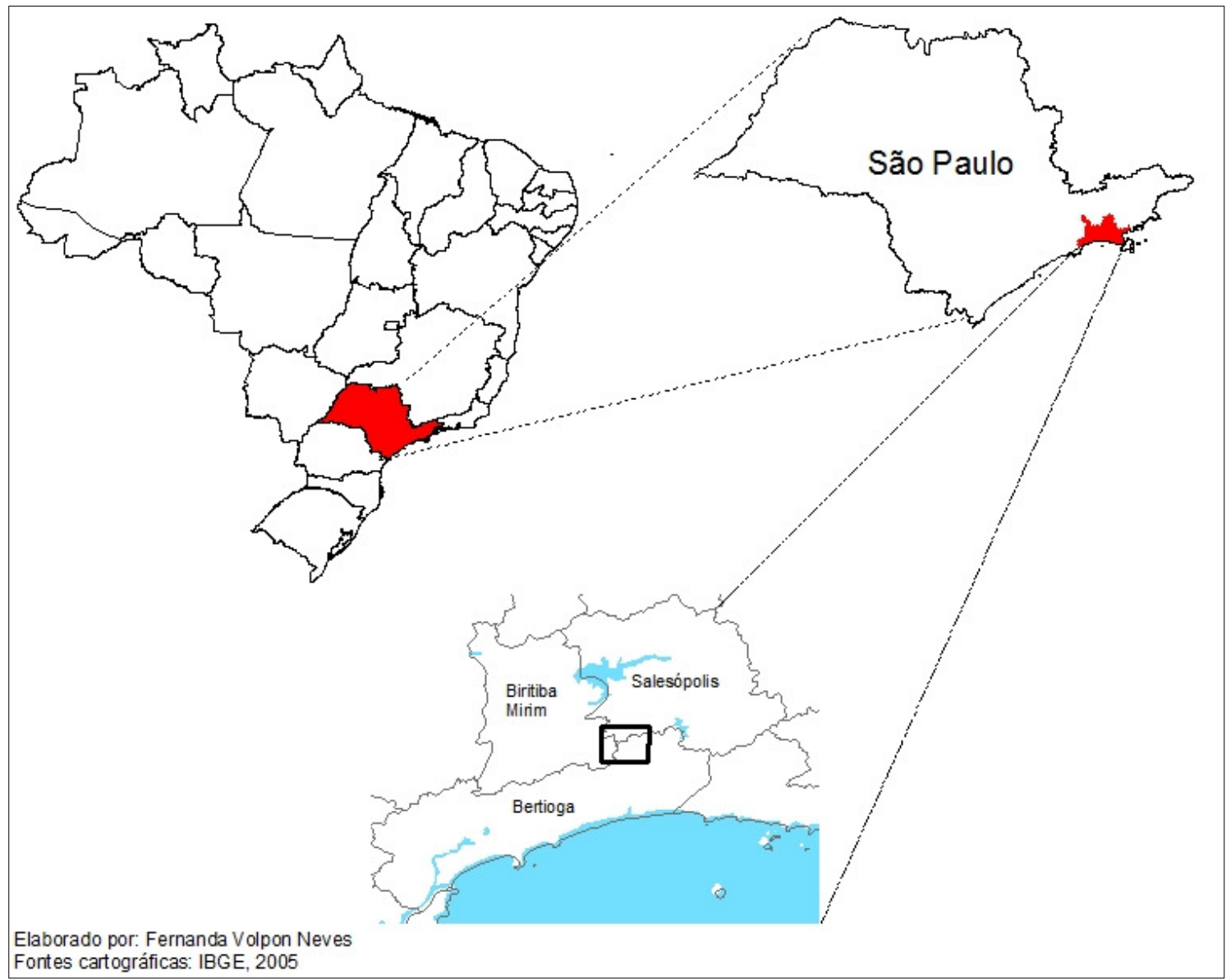

\subsection{Clima e Vegetação}

De acordo com as informações obtidas através das normais climatológicas do Instituto Nacional de Meteorologia (INMET) considerando-se o histórico de 1961 - 1990, o clima da região para as cidades de Ubatuba e Santos (a área de pesquisa fica entre as duas estações aqui citadas) e os níveis de precipitação total chegam a cerca de $2644,5 \mathrm{~mm}$ e $2080,8 \mathrm{~mm}$ ao ano, 
respectivamente. Já Conti \& Furlan (2005) apresentam que as médias de pluviosidade mais elevadas no estado de São Paulo aparecem no trecho da Serra do Mar, principalmente nas áreas entre Bertioga e Taiaçupeba apresentando isoietas de aproximadamente $4.000 \mathrm{~mm} / \mathrm{ano}$.

A vegetação ou o Bioma das regiões florestadas ocorrem de diversas maneiras, numa ampla variedade de formações vegetais. Os principais fatores que contribuem para o desenvolvimento da vegetação são umidade e temperatura. No quadrante da pesquisa a floresta é caracterizada como floresta tropical úmida (Foto 2.2-1). Esta floresta segundo Conti \& Furlan (2005) ocorre no Caribe, na Bacia Amazônica e na Mata Atlântica. Em alguns trechos da área de pesquisa a vegetação está bastante degradada devido a presença de estradas de acesso para as áreas de captação de água e suas adutoras. De modo geral a vegetação apresenta aspecto homogêneo (Foto 2.2-2), com diferentes níveis de estratificação (alturas das copas das árvores diversificadas), ocorrência de grande quantidade de orquídeas e samambaias, podendo avistá-las do lado de fora da mata fechada. Conti \& Furlan (2005) apontam que os "troncos das árvores nas florestas tropicais úmidas são verdadeiros jardins suspensos".

De modo geral, a Mata Atlântica é caracterizada por apresentar temperaturas máximas médias variando entre $18^{\circ}$ a $30^{\circ} \mathrm{C}$, acarretando em uma grande diversidade fitofisionômica. No inverno a região apresenta aspecto nebuloso, impossibilitando avistar a vegetação a sua frente. Essa característica de neblina ocorre ao longo de toda a serra do Guaratuba e entorno.

É muito interessante pensar a forma pela qual Conti \& Furlan (2005) descrevem as características da floresta tropical úmida, informando que a mesma apresenta de modo geral uma característica de um estado de desequilíbrio, 
diferentemente do que se pensava estar em total equilíbrio. Conti \& Furlan (2005) descrevem que essa mata atlântica seria sucessora de florestas que "foram perturbadas no último período glacial (semi-árido) do Pleistoceno".

Foto 2.2-1 - Vegetação ao longo do Cotovelo.

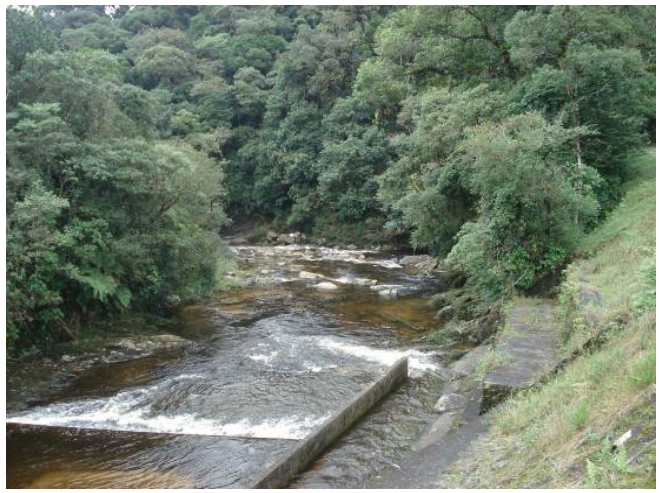

Fotografia de: Fernanda Volpon Neves. UTM: 408597/ 7382312

\section{Foto 2.2-2 - Vista do rio Guaratuba e} sua vegetação à montante da captação de água pela adutora.

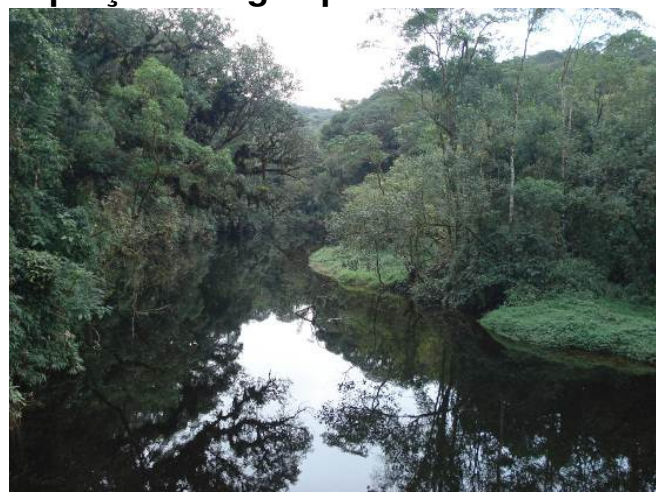

Fotografia de: Fernanda Volpon Neves. UTM: $408597 / 7382312$

\subsection{Hidrografia}

A finalidade em compreender a rede hidrográfica local está no auxílio do entendimento da evolução histórica de deposição de material sedimentar ao longo da planície de inundação do rio, tão como do depósito no leito fluvial do rio. Ademais, é o coadjuvante da pesquisa, uma vez que o rio Guaratuba e todo seu entorno, são testemunhos da evolução da drenagem local, e do ajuste que o relevo veio sofrendo ao longo de milhares de anos.

A drenagem foi mapeada através das cartas topográficas do IBGE (1:50.000 - Carta de Salesópolis) e do IGC (1:10.000), ambas trabalhadas no software ArcGis para auxilio na compreensão da complexidade da drenagem local. Ao longo de boa parte da área de pesquisa a estrada de captação de água do rio 
Guaratuba cruza os rios Claro e Guaratuba, assim como as adutoras que percorrem a Serra do Mar.

Como Rossi (1999) e Oliveira (2003) já observaram há um corredor (Figura 2.3-1) relativamente extenso que separa as drenagens dos rios Claro e Guaratuba. Este vale foi caracterizado como divisor de águas das duas bacias de drenagem. 


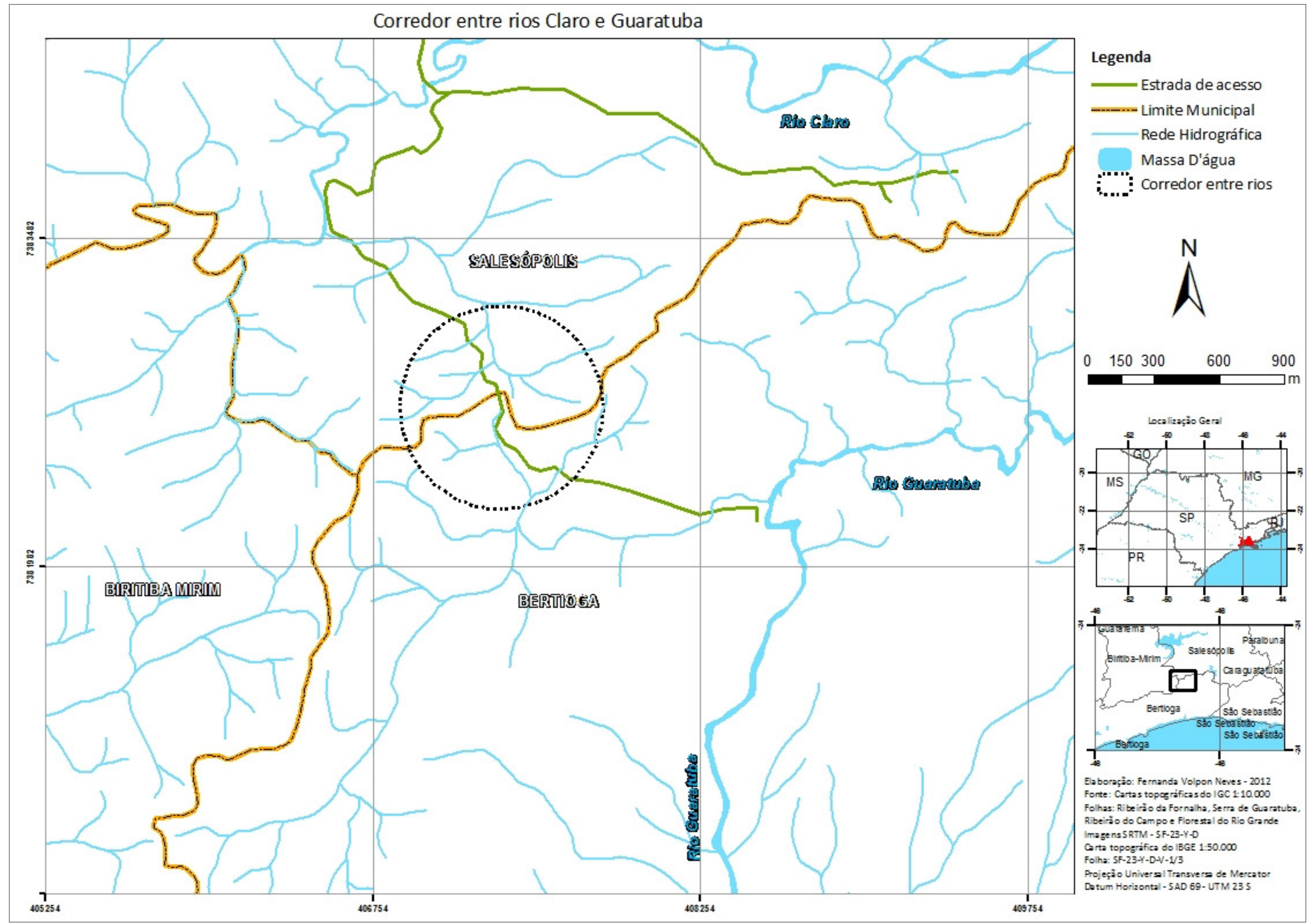

Fonte: Adaptado de Rossi (1999) e Oliveira (2003). 
No planalto a rede hidrográfica possui padrão de treliça à dendrítica, consequência do grande faturamento e falhamento existente na área, assim como o bandamento presente em todo o trecho caracterizando os rios com orientação preferencial de NE-SW (Rossi, 1999) e num segundo plano de N-S, com presença de rios com ângulos retos, consequência do alto controle geológico/estrutural.

Segundo Rossi (1999, sem paginação) a drenagem local pode ser subdividida em alguns trechos (Figura 2.3-2), sendo eles: A) a área central da bacia e altas vertentes de $E$, apresenta padrões de drenagem em treliça, denso, com rios mais curtos e lineamentos NE-SW; B) a área W da escarpa, considerando as altas, médias e baixas vertentes, apresenta padrão arborescente aberto, menor densidade de canais e rios mais longos; C) a área compreendida pela parte leste, padrão arborescente tendendo à sub-paralelo. No mapa abaixo nota-se a presença de uma categoria não elencada por Rossi (1999) que é o setor D, considerado como drenagem indefinida por Oliveira (2003). 
Figura 2.3-2 - Mapa dos exemplos de padrão de drenagem representativos para a área de estudo

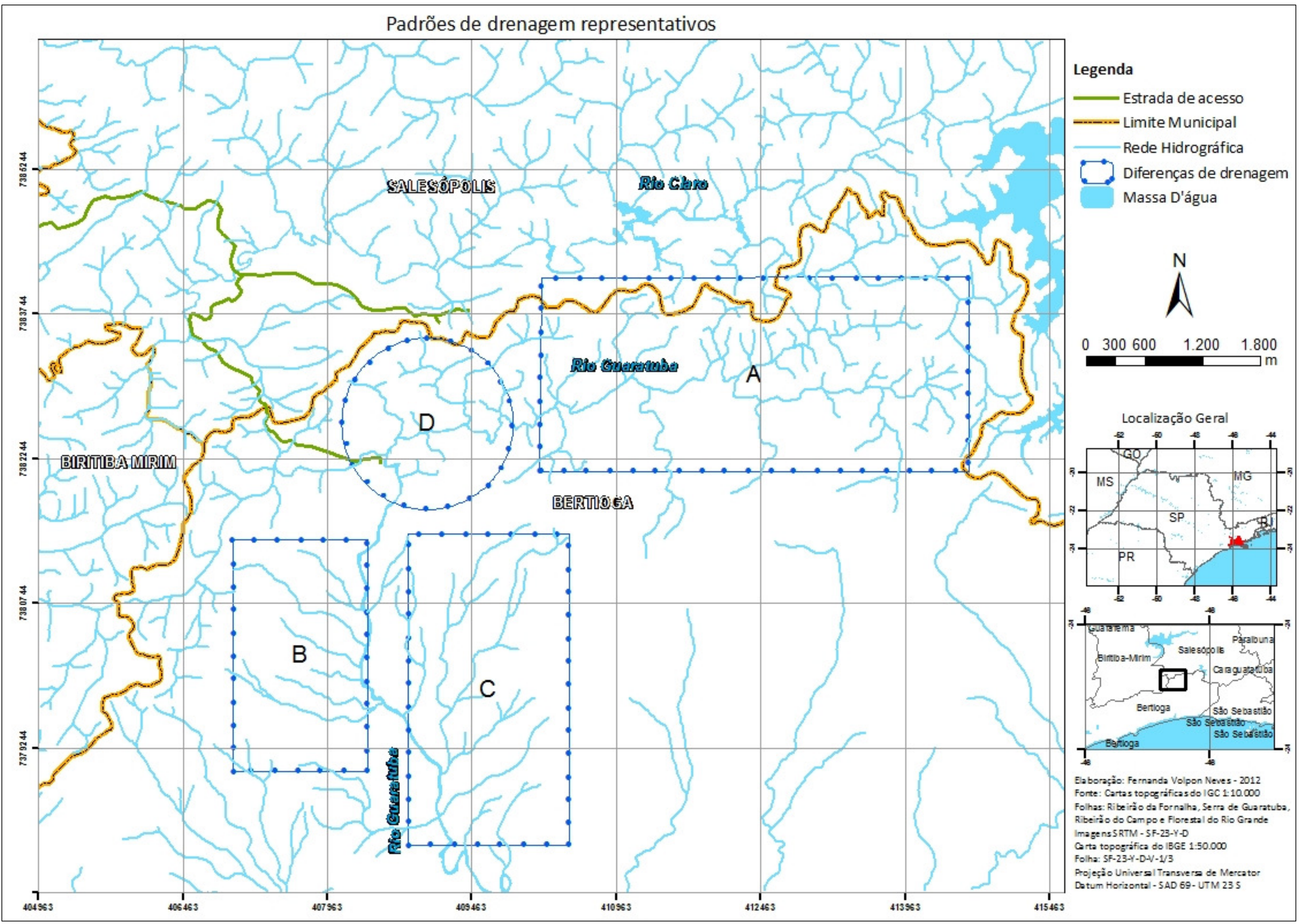


De acordo com Rossi (1999) a rede hidrográfica deve sintetizar os elementos, uma vez que reflete principalmente, o material de origem juntamente com solos e relevo. A fusão entre os elementos citados e os lineamentos de falhas e fraturas encontrados por toda a bacia, comprovam o controle da rede hidrográfica pela estrutura e natureza das rochas.

Segundo Christofoletti (1980) "os rios constituem os agentes mais importantes no transporte dos materiais intemperizados das áreas elevadas para as mais baixas e dos continentes para o mar".

Coelho Neto (in GUERRA \& CUNHA, 2007), relata que a água controla tanto a "formação como o comportamento mecânico dos mantos de solos e rochas". As formas do relevo das encostas sejam elas côncavas, convexas ou retilíneas, são determinantes para o resultado das ações realizado numa encosta (relação entre topo e fundo de vale) como os processos erosivos e deposicionais.

Os processos que envolvem o transporte de sedimentos estão associados aos processos erosivos e de deposição de material, levando em conta o comportamento de cada canal, considerando a velocidade, turbulência do fluxo do canal, carga existente e tipo de transporte (suspensão, saltação ou rolamento) (CUNHA in GUERRA \& CUNHA, 2007).

De acordo com Christofoletti (1981) a sedimentação do leito fluvial inclui os processos de remoção, transporte e deposição das partículas, envolvendo toda a dinâmica da bacia de drenagem.

Em virtude da ação impactante que o rio tem sobre o seu próprio leito é importante elucidar e interpretar, a evolução histórica da paisagem na escala geológica. O conhecimento minucioso das condições de produção, remoção, transporte e deposição dos sedimentos, é extremamente importante, porque 
refletem-se nas características das camadas sedimentares como "sedimentos correlativos" e vestígios das condições morfoclimáticas (CHRISTOFOLETTI, 1981).

É preciso tomar conhecimento sobre o estágio das margens dos rios a serem estudados. Segundo Christofoletti (1980), este estágio decorre da "premissa de que a forma e o padrão dos canais fluviais estão ajustados ao débito, aos sedimentos fornecidos pela bacia de drenagem e ao material rochoso componente das margens", ou seja, os rios apresentam em seu formato a resultante dos processos de degradação e agradação de material.

Quando o rio tem seu fluxo correndo através do canal tradicional de seu leito os processos erosivos são mais efetivos se comparados a períodos de extravasamento do canal. Nesses períodos mais agitados do rio, o mesmo se espraia, depositando e removendo material de locais que não fazem parte do canal principal, reduzindo a efetividade da erosão.

Christofoletti (1980) traz que cada canal fluvial pode ser estudado como um sistema morfológico, considerando-se o fluxo e material sedimentar como sendo dois elementos base da estruturação do sistema de geometria hidráulica. A geometria hidráulica é estudada para explicarmos as relações de transporte, dissecação, escoamento, retrabalhamento e deposição, dentre outros fatores e elementos relacionados ao rio e seu transporte.

De acordo com Christofoletti (1980) "é normal o fato de que os débitos cresçam em direção da jusante, principalmente nas regiões úmidas, verifica-se também que à medida que se eleva a vazão de um rio há aumento proporcional da largura e da profundidade do canal e da velocidade das águas”.

O transporte inicial de um grão se dá através de "torrentes pluviais e/ou movimentos gravitacionais nas encostas da serra, o grão é incorporado à carga dos 
rios e corredeiras da escarpa, através das quais atingirá o rio de mais baixo gradiente" que para o rio em questão e muitos outros são caracterizados pela planície litorânea. (GIANNINI \& RICCOMINI in TEIXEIRA et al 2003).

De acordo com Giannini \& Riccomini (in TEIXEIRA et al 2003) pode-se reconhecer três grandes cenários geográficos principais no entendimento dos grãos, seu transporte, área fonte e o nível de base, sendo eles na área de pesquisa : planalto, escarpa e planície costeira. Além de "quatro processos geológicos: intemperismo, erosão, transporte e deposição".

A ação do intemperismo segundo Giannini \& Riccomini (in TEIXEIRA et al 2003) é "diretamente proporcional ao tempo de residência em superfície do grão e da matéria-prima geológica em geral. Assim o intemperismo é menos atuante nas partes mais íngremes da escarpa, onde os processos de remobilização dos produtos de alteração são acelerados pela intensa ação da gravidade". Esse intemperismo é mais atuante no topo da serra e na planície litorânea, por consequência do baixo declive a longa manutenção de solos e depósitos sedimentares.

O clima é um fator intensificador da ação dos agentes intempéricos, os climas mais quentes e úmidos promovem uma maior desintegração e decomposição mais rápida do que em climas frios ou áridos. O relevo tem sua maior influência no tempo de ação dos agentes intempéricos e de desgaste mecânico. Relevos muito acidentados ou íngremes promovem um transporte abrupto e curto, conquanto relevos mais planos e suaves promovem transporte contínuo e prolongado com maior tempo de ação do intemperismo (GIANNINI \& RICCOMINI in TEIXEIRA et al 2003).

Os rios desembocam geralmente em drenagens com nível de ordem menor do que eles mesmos. Giannini \& Riccomini (in TEIXEIRA et al 2003) relatam 
que "o nível horizontal imaginário abaixo do qual a deposição predomina sobre a erosão e intemperismo e acima do qual erosão e intemperismo predominam sobre deposição recebe o nome de nível de base de erosão".

O nível de base muitas vezes é confundido com o nível do mar, mas neste caso é apenas para bacias que desembocam no mar. Para bacias que fluem para dentro do continente, o nível de base é aquele que o rio vai desaguar quando acabar seu curso, geralmente mudando sua toponímia. Os autores ressaltam que o nível de base pode sofrer alterações ao longo dos anos de acordo com as variações do nível relativo do mar.

Outra feição erosiva e modificadora do relevo ao longo dos canais fluviais são os terraços fluviais, formados quando o rio corta os sedimentos previamente depositados em sua planície de inundação, podendo ser esculpidos também sobre o embasamento rochoso (SUGUIO \& BIGARELLA, 1990).

De acordo com Suguio \& Bigarella (1990) os terraços são, em sua maioria, utilizados na chave de interpretação do histórico geológico regional, em sua maioria, as mudanças ambientais provocam a aceleração de processos erosivos dos próprios depósitos dos rios previamente formados. "A literatura clássica, geralmente refere estas mudanças como tectônicas, isto é, a região pode ter sido levantada ou basculhada alternando o nível de base dos rios", entretanto as grandes mudanças estão atreladas à alterações no clima que afetam a hidrodinâmica do sistema fluvial, influenciando principalmente na descarga líquida ou na carga sedimentar do rio (SUGUIO \& BIGARELLA, 1990).

Os depósitos de cascalhos constituem em grande parte a estrutura fundamental de muitos terraços fluviais, a ocorrência extensiva de terraços com cascalhos tem sido interpretada por alguns autores como exclusivamente de origem 
tectônica e, por outros, como registro de mudanças e eventos climáticos abruptos e rigorosos. No entanto vale ressaltar que, mesmo durante os movimentos tectônicos, os terraços e seus depósitos não teriam se formado, se não tivessem condições climáticas e hidrológicas apropriadas (SUGUIO \& BIGARELLA, 1990). 


\section{EMBASAMENTO TEÓRICO}

\subsection{Rede Hidrográfica e Captura Fluvial}

A rede hidrográfica ao longo da Serra do Mar é muito diversificada. Apresenta muitos padrões de orientação, em que a drenagem orienta-se principalmente no sentido NE-SW e NW-SE, como identificado por Rossi (1999). Apresenta ainda maior densidade dos canais e rios no planalto, alguns destes com controle estrutural a depender do local onde se encontram.

De acordo com Christofoletti (1980), o estudo sobre análise das formas e dos processos fornece conhecimento específico sobre o aspecto e a dinâmica da topografia atual, que, sob diversas condições climáticas possibilita compreender as formas do relevo, sejam elas esculpidas por forças destrutivas ou em ambientes deposicionais.

A carga transportada pelo leito fluvial revela um testemunho local de ocorrências de depósito em determinados pontos da vertente. A diversidade granulométrica que o leito fluvial pode apresentar varia de acordo com as condições temporo-espacial. (CHRISTOFOLETTI, 1981).

Segundo Cunha (in GUERRA \& CUNHA, 2007, p.214)

a fisionomia que o rio exibe ao longo do seu perfil longitudinal é descrita como retilínea, anastomosada e meândrica, constituindo o padrão dos canais. Essa geometria do sistema fluvial resulta do ajuste do canal à sua seção transversal e reflete 0 inter-relacionamento entre as variáveis descarga líquida, carga sedimentar, declive, largura e profundidade do canal, velocidade do fluxo e rugosidade do leito

Suguio \& Bigarella (1979) discutem que cada um dos fatores componentes da paisagem e evolução de drenagem de uma bacia estão sujeitos às influências geológicas e topográficas. "Entre os elementos importantes na definição 
das características hidrológicas de um sistema fluvial citam-se: 1) a altitude e orientação da bacia hidrográfica; 2) o relevo, forma e declividade da bacia de drenagem e; 3) a estrutura geológica, tipos de rocha e manto de intemperismo" (SUGUIO \& BIGARELLA, 1979).

A drenagem fluvial segundo Cunha (in GUERRA \& CUNHA, 2007) é constituída por canais de escoamento interligados. "A disposição espacial dos rios, controlada em grande parte pela estrutura geológica, é definida como padrão de drenagem" (HOWARD, 1967 apud GUERRA \& CUNHA, 2007). De modo geral a classificação dos padrões de uma drenagem é fundamentada na gênese, escoamento e geometria do canal fluvial.

De acordo com Suguio \& Bigarella (1979) os terraços fluviais são utilizados como chave da interpretação da história geológica regional em que, geralmente as mudanças ambientais, levam os rios a erodirem seus próprios depósitos previamente formados. A literatura clássica "geralmente refere estas mudanças como tectônicas, isto é, a região pode ter sido levantada ou basculada alterando o nível de base dos rios", no entanto os rios sofrem diversas modificações de clima, influindo em descarga hidrodinâmica do sistema fluvial e descarga líquida.

Diante do comportamento local de cada drenagem, das anomalias e características supracitadas, considerar-se-á a captura fluvial como um fenômeno que ocorre de diversas formas em todo o mundo, conhecidas por suas peculiaridades e sua dinâmica de formação. A captura fluvial ou River Piracy como também é conhecida, foi descrita e trabalhada por muitos autores, dentre eles consideramos a descrição mais importante e inicial o trabalho desenvolvido por Davis (1895) nos rios Sena, Mosa e Mosela. 
Segundo o trabalho de Davis (1895) os rios afluentes do Sena, Mosa e Mosela, migraram e alteraram seus cursos d'água em detrimento do desenvolvimento de novas drenagens. O autor descreve diversos canais fluviais menores que foram capturados e decapitados em função da evolução da drenagem.

O cotovelo de captura é abordado como:

\begin{abstract}
brusco desvio sofrido pelo trecho superior, no ponto onde ele é interceptado em proveito do curso d'água capturador. Após a captura, o curso d'água modificado escava um vale fortemente encaixado para jusante e para montante deste cotovelo, porque o curso d'água desviado, cujo volume é considerável, deve imediatamente aprofundar seu leito, tornando-se a cabeça do novo curso d'água que deve uni-lo ao rio capturador e cujo volume é ainda igual a zero (DAVIS, 1895, tradução de Oliveira, 2008).
\end{abstract}

Um dos primeiros autores brasileiros a tratar a captura fluvial foi Aziz Ab'Saber (1957), no seu artigo 'O problema das conexões antigas e da separação da drenagem do Paraíba e do Tietê' onde observou que a anomalia descrita por muitos autores havia sido detalhada de forma extremamente superficial. Em seu artigo Ab'Saber busca dar uma característica mais sistemática em comparação ao que havia de publicações à época. Ab'Saber (1957) apresenta um embasamento paleogeográfico para o estudo do que possa ter acarretado a captura do rio Paraíba com sua total inversão de curso se afastando do rio Tietê.

Lester King (1956) relata em 'A geomorfologia do Brasil oriental' a captura que ocorreu no Alto e Médio Paraíba, citando que as "antigas cabeceiras do Tietê foram anexadas pelo rio Paraíba, constituindo um exemplo clássico de captura fluvial". King atribui a uma origem tectônica as vantagens do rio Paraíba sobre o Tietê, favorecendo a sua pirataria.

De Martonne (1943) relata sobre esta captura do Paraibuna/Paraitinga pelo Paraíba como sendo uma das maiores dissecações que ocorrera no interior da 
Serra do Mar, pois ela se encaixa nas formações pliocênicas muito extensas. Peculiar também considerar que este rio encontra-se cerca de 150 metros rebaixado do rio Tietê, seu antigo curso.

De acordo com Christofoletti (1975) a captura fluvial (river piracy ou stream piracy) é o processo natural de desvio das águas, onde uma bacia fluvial "rouba" água de outra bacia. A captura fluvial pode acontecer de várias maneiras, sendo elas: "absorção", "recuo das cabeceiras", "aplanamento lateral", "transbordamento" ou "desvio subterrâneo".

O recuo de cabeceiras é a forma de pirataria de drenagem mais estudada e pesquisada. Christofoletti (1975) descreve de forma sucinta este fenômeno que ocorre em locais nos quais os dois rios capturador/capturado são adjacentes com altitudes distintas. Os tributários do curso mais baixo provocam a erosão regressiva de suas cabeceiras, de modo que este atravessa o interflúvio e captura o curso de água localizado em nível mais alto.

Christofoletti (1977, p.96) complementa seus trabalhos com uma publicação na qual relata que o

rio é o canal de escoamento que funciona pelo abastecimento que lhe é fornecido. A potência erosiva está ligada a esse abastecimento, em água e em detritos, e não à declividade do canal. Para que o rio exista e funcione deve sempre haver uma área que lhe garanta o abastecimento, constituindo a sua bacia de drenagem.

Segundo Christofoletti (1977) todas as contribuições acerca do tema de captura fluvial foram elaboradas através das pressuposições da teoria davisiana em que, considerando o equilíbrio dinâmico, o rio seria um "sistema aberto, funcionando através do fluxo de matéria e energia".

Oliveira (2003) em sua tese apresenta algumas imagens de modelo de evolução (Figura 3.1-1) do relevo que são modelos do Guaratuba, baseando-se 
nelas pode-se desenvolver melhor as discussões acerca da captura fluvial. Para que se possa melhor compreender a evolução e por consequência desenvolver as técnicas de datação por Luminescência, uma vez que a datação será utilizada para comprovar e elucidar a evolução da morfologia proposta por Oliveira (2003).

Figura 3.1-1 - Modelos de evolução da bacia do alto Guaratuba.

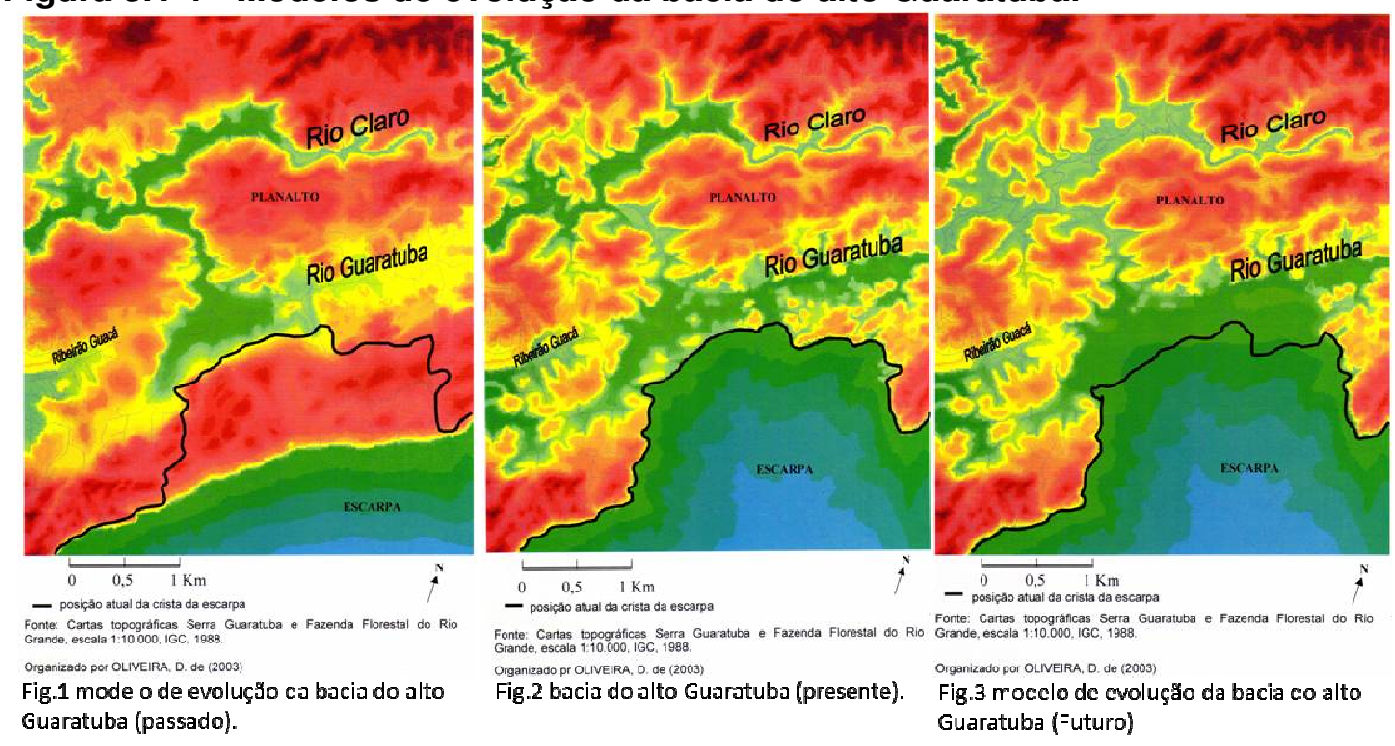

Fonte: Oliveira, 2003.

Coelho Neto (2003) conclui que a "evolução das cabeceiras de drenagem pode ser modelada a partir da integração dos processos químicos e físicos responsáveis pela formação e denudação dos regolitos". Aponta ainda que a paisagem regional litorânea é instável e heterogênea, "submetida a mudanças ambientais cada vez mais rápidas e a altas taxas de erosão e deposição, nas encostas e fundos de vales fluviais". Estes por sua vez, tendem a tornar-se cada vez mais vulneráveis, desencadeando processos erosivos, aumentando a "ocorrência de desastres naturais relacionados à água". 


\subsection{A Serra do Mar}

A Serra do Mar está situada na costa do Atlântico ao longo de todo o litoral Paulista seguindo para norte até o sul Baiano, domínio correspondente à essa área de profunda decomposição das rochas e de máxima presença de mamelonização, alterando rochas cristalinas atingindo seu maior desenvolvimento (AB'SABER, 1966). Seria portanto, um grande fronte dissecado de falhas em que termina o Planalto Atlântico (ALMEIDA \& CARNEIRO, 1998).

Os precursores da interpretação do relevo no Brasil podem ser considerados Washburne (1930) e De Martonne (1943/1944), os quais interpretam todo o relevo do Estado de São Paulo e Sudeste do Brasil. As cadeias de montanhas do sudeste do país são detalhadamente discutidas no livro de Washburne (1930) que elabora textos acerca da estratigrafia, geologia e estrutura do litoral e relevos do interior do estado.

De Martonne (1943) relata em seu artigo que a porção de terra que se deve discutir na morfologia moderna é justamente o maciço atlântico, áreas estas que ultrapassam em alguns pontos mais de 2000 metros de altitude, se estendendo desde a Baixada Santista até o litoral Baiano. As serras ao longo de todo o litoral são os pontos de cumeeira que se comportam como divisor de águas, sendo que as capturas aparecem surpreendendo pela sua "relativa raridade", sendo que todas as drenagens locais correm para o interior do estado de São Paulo com exceção de dois rios, Doce e Paraíba.

O relevo do estado de São Paulo tem sua extensão voltada para o Paraná que após um trecho de planícies, que lembram a depressão periférica chega-se até 
à Cuesta de Botucatu, que segundo relatos de De Martonne (1943) pode ser considerada área de dissecação dos ciclos erosivos do paleógeno.

Rochas resistentes sustentam planaltos e escarpas que, segundo Almeida \& Carneiro (1998), enquanto falhas, zonas de cisalhamento, fraturas e grandes domínios de rochas supra crustais, condicionam lineamentos maiores e segmentos locais de rede de drenagem. "Evidências de reativação têm sido descritas para muitas das principais zonas de cisalhamento e falhas regionais do sudeste brasileiro" (ALMEIDA \& CARNEIRO, 1998).

O domínio compreendido pela Serra do Mar - domínio de mares de morros - é a região do país de mais difícil acesso às ações antrópicas, em contrapartida é uma das áreas com mais fortes processos erosivos, e de movimentos coletivos de solos em todo o território brasileiro (AB'SABER, 1966). As classes de declividade são variadas, abrangendo planícies no reverso imediato da serra e no topo, assim como ao longo das principais planícies de drenagem, a predominância de declividade é de 4-30\%.

Ab'Saber (1966) elenca algumas características fisiográficas como fazendo parte desta área de mares de morros, sendo elas:

- decomposição das rochas cristalinas e cristalofilianas, chegando à $60 \mathrm{~m}$ de profundidade;

- presença de latossolo vermelho amarelo nas vertentes e interflúvios dos morros arredondados, desenvolvidos sobre depósitos de cobertura elúvio-coluviais posteriores às stone-lines;

- superposição de solos às derradeiras flutuações climáticas do Quaternário, com aparecimento das linhas de pedras enterradas entre 
1,5-2m de profundidade, representando paleopavimentos detríticos inhumados por depósitos de coberturas coluviais;

- mamelonização das vertentes baixas e médias, atingindo níveis altimétricos de 1100-1200m;

- área em que se processou um máximo de camuflagem das feições geomórficas herdadas de fases climáticas anteriores, tais como: superfícies aplainadas, pedimentos, terraços climáticos, inselbergs e cabeçeiras em anfiteatro, devido à extensividade dos processos de mamelonização.

- drenagem perene até os menores ramos da rede hidrográfica, altamente dendrificada e muito densa.

- presença de calhas aluviais, em setores de vales subsequentes ou vales adaptados a diaclases tectônicas, ângulos de falha ou falhas.

Para De Martonne (1943) a Serra do Mar apresenta como aspecto mais comum do relevo de domínio de rochas antigas como apresentando colinas onduladas, cortadas por vales e dominadas por cristas ou escarpas. A altitude média das colinas aparece singularmente uniforme, a das cristas e escarpas aparece variável, ora muito brusca, ora muito lenta.

De Martonne (1943) observou as grandes superfícies de erosão do litoral brasileiro e denominou a região da Serra do Mar como "superfície dos campos", no entanto esta denominação fica um pouco limitada se comparada à complexidade local. Em suas primeiras conclusões ele relata a presença e constatação de três superfícies de erosão. A mais recente, cuja idade determinada é neogênica, tem o seu maior desenvolvimento na bacia do Paraíba e no Alto Tietê, onde foi 
ligeiramente empenada e reduzida ao desabamento que fez chegar o Oceano ao pé do degrau tectônico da serra do Mar. As cristas Apalachianas denominadas por De Martonne (1943) de "superfície das cristas médias" parecem concordar com a Cuesta de Botucatu e seria relacionada ao ciclo de erosão paleogênica.

Almeida \& Carneiro (1998, p.137) apontam em seu artigo que a superfície mais antiga da Serra do Mar foi o que De Martonne (1943) identificou como "Superfície das Cristas Médias e por Almeida (1958) denominada de Japi".

Durante a deformação da superfície Japi, o planalto atlântico sofreu desnivelamentos por falhas, desenvolvendo semigrábens com inclinação NNW, orientados segundo direções ENE dos falhamentos pré-cambrianos então reativados. Ao considerar o nivelamento dos cimos da Serra do Mar pelas superfícies de aplainamento do Japi e do Alto Tietê, houve a elaboração e formação deste trecho do Planalto Atlântico que se estendia mais para leste, ocupando hoje parte do que seria a plataforma continental (ALMEIDA \& CARNEIRO, 1998).

Quando De Martonne (1943) faz as relações do relevo com a estrutura, distinguindo no maciço antigo, muitos domínios diferentes, sendo eles:

- O das Serras Litorâneas, onde a orientação SO-NE do relevo e da rede hidrográfica corresponde à das camadas de gnaisse, mas onde os grandes desnivelamentos são devidos a um jogo de blocos deslocados por falhas ou flexuras;

- O domínio da série metamórfica, caracterizado por cristas de rochas duras descontínuas e de orientação variável;

- O domínio da plataforma do Alto Rio Grande, vasta extensão de relevo ondulado, elevando-se insensivelmente de 1000 a 1200-1300m, relevo maduro tendo sido perpetuada desde o Terciário ou mesmo do Cretáceo; 
- Distinguiu-se quatro superfícies de erosão, sendo a mais baixa indicada como idade neogênica, quanto a mais elevada pode-se pedir uma ligação hipotética com a frente da cuesta de arenitos réticos guarnecidos de basaltos;

- Na "superfície dos campos" duas hipóteses poderiam ser consideradas: ou bem a superfície esteve no Cretáceo, em relação ao arenito Bauru, sendo a superelevação devida aos movimentos terciários; ou bem ele derivaria da superfície pré-permiana, cujo declive diminuiria para o centro de um abaulamento.

Segundo Modenesi-Gauttieri et al (2001) o relevo do sudeste do Brasil tem influência residual da sismicidade que ocorreu antes do cenozóico. O relevo mostra a herança dos processos tectônicos datados do Cenozóico, que se seguiram à reativação Mesozóica-Cenozóica e a abertura da bacia do Oceano Atlântico Sul. Durante o Paleógeno, uma reativação normal do antigo brasiliano provocou zonas de cisalhamento as quais apresentam características marcantes tectônicas.

Estes rifts tem sua extensão ao longo da Serra do Mar com direção Lestenordeste (ENE) de aproximadamente $1000 \mathrm{~km}$ de extensão, compreendendo as seis principais bacias cenozoicas - Curitiba, São Paulo, Taubaté, Resende, Volta Redonda e Macacu. A bacia de Taubaté é a mais importante - uma pequena depressão compreendendo Itaboraí e Barra de São João, e os grabens de Sete Barras e Guanabara. (MODENESI-GAUTTIERI et al, 2001)

No extremo leste do estado de São Paulo esta zona de rift e cisalhamento é expressada pela Serra do Mar e Serra da Mantiqueira. A história térmica da Serra do Mar mostra duas fases de resfriamento, tendo sido elas acentuadas durante 0 
Cretáceo e o Pleistoceno. Durante o quaternário, houve um retrabalhamento da superfície morfotectônica operando em condições de alta altitude - mais frio e climas úmidos - desenvolvendo campos altos de paisagens nas zonas altas do planalto acima dos níveis de base local nos córregos subsequentes. (MODENESIGAUTTIERI et al, 2001)

Bigarella, Mousinho \& Silva (1965), consideraram o clima como o principal fator na evolução das vertentes, sendo as mudanças climáticas as responsáveis pelo aspecto policíclico do relevo. A concavidade inferior teria sua origem a partir do espessamento do material coluvial, como resultado do escoamento superficial. $\mathrm{Na}$ fase seca haveria forte concentração das precipitações, fraco intemperismo químico e baixa densidade vegetal.

De acordo com Penteado (1969) terraços aluviais tem seixos bem rolados (retrabalhados de cascalheiras anteriores) onde o elemento essencial é o quartzo, sem relação com formações geológicas circundantes. Os pedimentos detríticos caracterizam-se por uma composição litológica semelhante a das rochas adjacentes, os elementos são mal rolados, transporte curto.

Assim, as encostas submetidas a estas variações ambientais apresentariam uma variedade de formas que refletiriam uma relação complexa entre os processos morfogenéticos passados e os atuais (BIGARELLA \& MOUSINHO, 1965).

Washburne (1939) descreve algumas falhas normais próximas à costa marítima, paralelas a levantamento à W-NW, além de outras dobras, como o próprio autor as descreve sem importância, paralelas às falhas com orientação para o NE, nos estratos Terciários do vale do Paraíba e na cidade de São Paulo. 
Segundo Casseti (1994, p.60), as oscilações climáticas pleistocênicas foram responsáveis pela diferenciação dos processos morfogenéticos, pelas diferenciações das formas erosionais e dos depósitos correlativos. Ele conclui que:

o clima árido ou semi-árido responde pela evolução horizontal da paisagem, através do recuo paralelo das vertentes, alargando vales, como as calhas aluviais atuais, ou processando a destruição de formas elaboradas nos climas úmidos, chegando a condição de aplainamento. Por outro lado, o clima úmido é responsável pela evolução vertical do relevo, através do entalhamento da drenagem, o qual apresenta variação em relação a intensidade dos esforços tectônicos ou gradiente do canal.

Segundo Bigarella \& Mousinho (1965) a evolução do relevo brasileiro após o Cretáceo, se dá a partir de alternâncias climáticas de Tropicais (interglaciais) para árida à semi-árida (glacial), caracterizando o que podemos chamar de uma evolução poligênica do relevo. O produto final na paisagem é a constituição de extensos aplainamentos e sua posterior dissecação em clima tropical (Biostasia). Depósitos Correlativos resultantes de fenômenos erosionais durante um clima semiárido, de acordo com Bigarella, Mousinho \& Silva (1965), são sequências sedimentares resultantes dos processos de agradação, simultaneamente com fenômenos de degradação na área fonte.

Dadas as constantes alterações no modelado do relevo, assim como nas formas de drenagem, Oliveira (2003) refere-se às formações mais recentes como áreas de declives mais acentuados, relata ainda que os níveis de base em "função do tectonismo post-cretáceo (...) forçaram uma inversão progressiva de partes das drenagens que iam para o interior", mudando seu curso em direção ao litoral através de "múltiplas capturas" termo usado por AB'SABER (1954 apud OLIVEIRA 2003). 


\subsection{Datação de material sedimentar}

A determinação de idades de solos e rochas por Luminescência

Oticamente Estimulada (LOE ou OSL - em inglês) tem tido uma utilização muito mais frequente nos últimos anos permitindo estabelecer a idade dos sedimentos, materiais arqueológicos ou superfícies que há muito estavam enterradas. A grande vantagem desta técnica é que a luminescência é capaz de identificar desde amostras muito jovens até centenas de milhares de anos com excelente precisão (CUNHA, 2010). As datações por LOE baseiam-se na avaliação do tempo decorrido desde que os grãos de quartzo e feldspato foram expostos à luz solar pela última vez (MARTINS \& CUNHA, 2006).

De acordo com Cunha (2010) a única exigência da datação é que seja feita em "quartzo ou feldspato potássico (principais minerais usados como dosímetros $\left.{ }^{2}\right)$.

O método de Datação por LOE é exemplificado e discutido por Duller (2004), onde ele relata que Luminescência é certamente um tópico complexo, mas em essência, o uso do fenômeno para datar eventos Quaternários é muito simples. Muitos minerais comuns, incluindo o quartzo e muitos feldspatos são capazes de armazenar energia. A energia passa pelo cristal que radiações ionizantes (ex. alfa, beta e gama) a partir do ambiente, mas também há uma boa contribuição a partir dos raios cósmicos (DULLER, 2004).

A energia armazenada se eleva com a quantidade de radiação para a qual o cristal é exposto, disto provém o "clock" que é a base de todo método de

\footnotetext{
${ }^{2}$ Dosímetros são instrumentos que indicam a exposição ou a dose de radiação, absorvida a que um indivíduo foi submetido. No caso dos minerais acima descritos, são aqueles que apresentam em sua característica, capacidade de armazenamento de energia e liberação da mesma quando estimulado.
} 
datação por luminescência (and electron spin resonance). No laboratório a energia armazenada no cristal pode ser liberada por estímulos, e uma porção desta energia é liberada em forma de Luz. Essa luz é conhecida por luminescência (DULLER, 2004).

O método de determinar a taxa de dose manteve-se similar nos últimos $10-20$ anos, com mudanças relativamente pequenas nas constantes numéricas usadas para converter abundâncias (ex. ppm ou $\mu \mathrm{g} \mathrm{g}^{-1}$ uranio ou tório, e \% de potássio) da forma elementar das doses de radiação e algumas mudanças na tecnologia utilizada (DULLER, 2004).

De acordo com Duller (2004), para datar sedimentos do Quaternário existem dois métodos de estimular a Luminescência, o termal e o óptico. Medições na década de 1980 envolveram aquecimento da amostra na temperatura da câmara escura para aproximadamente $500^{\circ} \mathrm{C}$ a fim de gerar um sinal de termoluminescência (TL). A estimulação Óptica (LOE) é preferível para datar sedimentos e gerar um sinal de luminescência óptica estimulada.

A datação LOE tem vantagem sobre a datação TL em que as medições preferenciais são feitas com a parte do sinal de luminescência que é mais sensível a luz, e assim o sinal LOE é levado a zero quando exposto a luz muito mais rapidamente e completamente do que o TL. Isso tem duas implicações: primeiramente os sedimentos requerem períodos mais curtos de exposição à luz do dia no processo de deposição, quando datados usando a LOE do que a TL, em segundo lugar porque a incerteza no grau em que o sinal é levado a zero é menor, desse modo as amostras recentes podem ser datadas com melhor resultado. (CUNHA, 2010). 
A Luminescência é utilizada para determinar o tempo decorrido desde que o sedimento foi exposto à luz pela última vez. Este sedimento recebe radiação ionizante proveniente de elementos existentes em toda parte da terra (ex: Tório, Urânio e Potássio). A partir do momento que este sedimento for depositado ou soterrado ele passa a receber uma quantidade menor de elementos radioativos. A partir do momento em que o material é soterrado, ele mantém no cristalino do mineral, cargas elétricas que quando liberadas representam a Paleodose (CUNHA, 2010). Na Luminescência opticamente estimulada (LOE) a amostra é excitada por um processo óptico para que emita feixes de luz em resposta à excitação. Portanto, é a liberação desta radiação armazenada que será propagada que dará a dose (Dose Equivalente) de emissão daquele elemento.

De acordo com Cunha (2010) os grãos minerais de quartzo e feldspato potássico são utilizados como dosímetros. Num equipamento específico leitor de luminescência, a amostra pura (limpa) dos minerais é preparada para a incidência de luz. A partir do momento que este mineral tem contato com a irradiação de luz liberam a energia de seu interior, obtendo-se assim a Dose equivalente (expressa em Gray $\left.(G y)^{1}\right)$. Esta paleodose deve ser comparada ao material em loco, ou com parte da amostra encaminhada ao laboratório. A paleodose (dose equivalente, a partir da amostra pura) será apresentada em taxas médias de radiação, pois cada 01 miligrama de mineral puro deverá resultar em uma dose aproximada. Deve-se fazer cerca de 20 amostras de 01 miligrama de mineral puro por amostra de solo para obter a dose média.

Segundo Miyamoto (1973) a taxa de dose é determinada a partir da contagem da radiação alfa emitida pelos radionuclídeos do urânio e tório existentes nas peças e solos avaliados por ele. 
De acordo com Miyamoto (1973, p. 2 e p. 3),

a irradiação produz na região do Ultravioleta, bandas de absorção devido a diversos tipos de centros induzidos pela radiação nos cristais. A luminescência produzida pela excitação de alguns desses centros com luz ultravioleta é proporcional ao número de centros criados e este por sua vez é proporcional à exposição recebida dentro de um intervalo de exposição. Logo, a luminescência é proporcional à exposição recebida.

Para determinar a idade do material coletado, é necessário fazer a relação da dose equivalente do material com a dose anual. A dose anual é a obtida através da contagem da energia proporcional acumulada pela radiação ionizante que atravessou o material. Esses elementos radioativos estão presentes no planeta a milhares de anos. O decaimento radioativo é natural e a dose anual é justamente a medida desse decaimento que foi estimulado na amostra. A dose anual é obtida através do material de solo extraído próximo ao material da amostra que fornecerá a dose equivalente, material bruto, em sua forma original de sedimento. 


\section{MÉTODOS, TÉCNICAS E PROCEDIMENTOS GERAIS}

Para se alcançar os objetivos propostos nesta pesquisa, foi necessário elencar diversas etapas e métodos principalmente voltados para a seleção do material e trecho da área de pesquisa onde seriam desenvolvidas as datações dos sedimentos.

\subsection{Métodos}

Este trabalho tem como base metodológica o trabalho de Ab'Saber (1969) sobre a forma de se estudar o Quaternário e, consequentemente, sua Geomorfologia. Através deste estudo de Ab'Saber $(1969$, p. 2) difundiu o conceito de que há 3 "níveis de tratamento" para a execução dos trabalhos, sendo eles:

1 - "A Geomorfologia é um campo científico que cuida do entendimento da compartimentação da topografia regional, assim como da caracterização e descrição, tão exatas quanto possíveis, das formas de relevo de cada um dos compartimentos estudados";

2 - “(...) procura obter informações sistemáticas sobre a estrutura superficial das paisagens referentes a todos os compartimentos e formas de relevo observados (...)".

3 - "Geomorfologia moderna cuida de entender os processos morfoclimáticos e pedogênicos atuais em sua plena atuação, ou seja, procura compreender globalmente a fisiologia da paisagem através da dinâmica climática e de observações mais demoradas e sob controle de equipamentos de precisão". 
Diante desta estrutura proposta por Ab'Saber (1969) optou-se por utilizar a abordagem de uma análise morfológica de execução deste trabalho apenas nos tópicos 1 e 2 para que a pesquisa se desenvolva buscando resultados nas informações sistematizadas.

1 - Compartimentação do relevo e caracterização das formas;

2 - Informações sistemáticas sobre a estrutura superficial das paisagens.

Desta forma, os elementos físicos da paisagem foram compartimentados em patamares para a elaboração de mapas temáticos propiciando um estudo integrado das informações coletadas em campo, trabalhos de gabinete, revisão bibliográfica, aquisição de material cartográfico, juntamente com outras atividades de campo e laboratório.

Como forma de exemplificar os processos desenvolvidos neste trabalho, abaixo o fluxograma (Figura 4.1-1) das etapas metodológicas da pesquisa e dos procedimentos técnicos desenvolvidos. 
Figura 4.1-1 - Fluxograma das etapas metodológicas e dos materiais

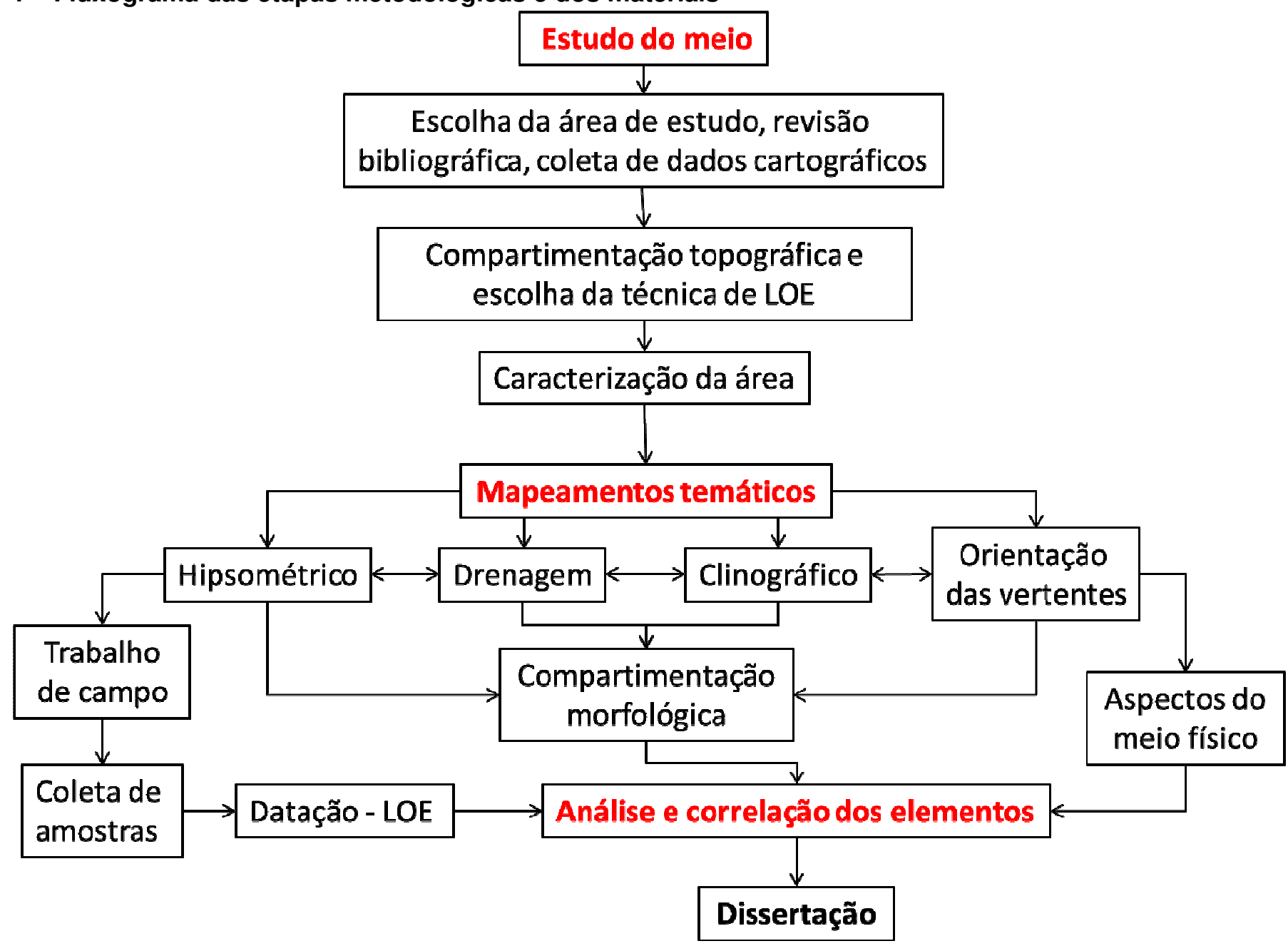

Elaboração: Fernanda Volpon Neves, 2012 


\subsection{Técnicas e Procedimentos Gerais}

\subsubsection{Levantamento e pesquisa bibliográfica}

A pesquisa bibliográfica foi realizada com o objetivo principal de selecionar os principais trabalhos envolvendo a Serra do Mar, Datação por LOE e Características Geológicas da área a fim de embasar discussões acerca da evolução do relevo, hidrografia, Capturas fluviais e Luminescência Opticamente Estimulada. A pesquisa foi desenvolvida com conteúdos bibliográficos coletados em diversas localidades como também material emprestado por professores e até mesmo arquivos pessoais. As consultas on-line foram frequentes uma vez que há uma gama de livros e de artigos que são divulgados e acessíveis em rede.

\subsubsection{Fontes cartográficas e vetorização}

Objetivando a estrutura da pesquisa proposta por Ab'Saber (1969) foi realizada a compartimentação topográfica da área. Esta compartimentação foi desenvolvida a partir de produtos cartográficos onde optou-se por utilizar como embasamento para a confecção dos mapas temáticos, as cartas topográficas do Instituto Geográfico e Cartográfico (IGC) 1:10.000 e as cartas topográficas do Instituto Brasileiro de Geografia e Estatística (IBGE) 1:50.000. A escolha das cartas topográficas do IGC foi baseada na escala do mapa, item importante para o desenvolvimento da pesquisa e mapeamento da área.

As cartas do IGC 1:10.000 têm em suas curvas distância de 5 metros. Asas do IBGE tem uma distância entre as curvas de 20 metros. A menor distância 
entre as curvas apresentadas nas cartas do IGC proporciona, a partir da vetorização, uma escala de riqueza e detalhes na confecção dos mapas maior, se comparada com os produtos gerados a partir das cartas do IBGE.

Para os mapas temáticos mais específicos, as cartas foram elaboradas baseadas nas cartas topográficas do IGC 1:10.000 para que os erros fossem minimizados, evitando divergência de informações. Todo o material cartográfico, somando-se as imagens de satélite (CBERS - INPE e SRTM - NASA), foi utilizado para elucidar através da produção de mapas, as formas de relevo que a área apresenta.

As cartas do IGC utilizadas foram as seguintes folhas: Fazenda Florestal do Rio Grande (SF.23-Y-D-V-1-SO-B), Represa Ribeirão do Campo (SF.23-Y-D-V-1SE-A), Serra Guaratuba (SF.23-Y-D-V-1-SO-D) e Ribeirão da Fornalha (SF.23-Y-DV-1-SF-C). Do IBGE utilizou-se a folha: Salesópolis (SF.23-Y-D-V-1/3)

Como forma de conferir as feições percebidas em campo e a partir das produções das cartas temáticas, fotografias aéreas de 1962 foram utilizadas na escala 1:25.000 através da técnica de estereoscopia, para a simples identificação do relevo mapeado. Utilizou-se o Google Earth para conferir e confrontar o que fora encontrado anteriormente. Como descrito acima os materiais consultados apresentaram diferentes escalas, este fator não gera problemas, entretanto, a sobreposição não é possível, apenas servindo no formato de conferência das informações e comparação nos diferentes documentos.

Para a elaboração e desenvolvimento dos mapas temáticos foi utilizado o software ArcGis versão 9.3. Através dele, realizou-se a vetorização dos dados contidos na carta como: curvas de nível, hidrografia, estradas de acesso, pontos de importância. As cartas citadas foram digitalizadas e inseridas no software ArcGis 9.3 
para que as mesmas fossem georreferenciadas e ajustadas, encaixando-as perfeitamente umas nas outras (de mesma escala) para a vetorização dos dados.

As informações contidas nas cartas do IGC e IBGE foram vetorizadas, isso significa que, os dados foram desenhados em detalhe respeitando uma acurácia de escala de 1:2.000, para que, a partir da vetorização, fossem transformados em shape. A partir do momento que se tem o shape pronto com a informação dada, é possível gerar qualquer produto do local de acordo com as informações que se espera obter.

A vetorização tem de ocorrer de forma que um vetor proporcione a melhor compreensão de pontos mais complexos ou que precisem de maior atenção. Iniciase a vetorização pelas curvas de nível uma vez que as mesmas podem ser comprobatórias para elaboração da drenagem e pontos de importância nas cartas. A drenagem foi desenhada logo na sequência uma vez que o rio é o objeto de estudo desta pesquisa, sendo que o mesmo necessita de uma atenção ainda maior quando identificado.

Os mapas a serem apresentados a seguir, representam o que se poderá encontrar na área a respeito da hipsometria, clinografia, orientação das vertentes, dentre outros.

\subsubsection{Carta hipsométrica}

A carta hipsométrica é gerada a partir das curvas de níveis anteriormente vetorizadas. No software ArcGis há uma extensão chamada 3D Analyst a partir do qual pode-se gerar automaticamente qualquer produto, escolhendo sua forma de representação. Após a escolha do formato da informação que estiver sendo gerada, 
é possível trabalhar as categorias de classes diferenciadas, tais como altitude, cores, entre outros; tudo aquilo possível de ser retrabalhado a partir da geração das curvas, o programa permitirá sua execução. O formato escolhido para gerar a carta hipsométrica no ArcGis foi o elevation ${ }^{3}$.

As categorias definidas para esta carta hipsométrica são de sete tipologias diferentes, respeitando-se um padrão de espaçamento igualitário de 130 em 130 metros. Esta compartimentação foi realizada para que o produto final gerasse patamares bem representativos da realidade do local.

\subsubsection{Carta de Declividade}

Na carta de Declividade as categorias das classes de Declividade são nove, variando em tons de verde. Quanto mais escuro o tom, maior a declividade. As classes de declividade são muito discrepantes, variando de $0^{\circ}$ a $90^{\circ}$ de inclinação.

Para elaboração desta carta foi utilizada a mesma técnica da geração da carta hipsométrica, no entanto, o que as diferencia é a escolha da forma de representação. Utiliza-se o 3D Analyst para gerar a informação em profundidade, representando-o no formato slope ${ }^{4}$.

\footnotetext{
${ }^{3}$ Face elevation with graduated color ramp. Ferramental do ArcGis que gera automaticamente as classes de compartimento do relevo, considerando as curvas de nível e construindo os intervalos. ${ }^{4}$ Face slope with graduated color ramp. Ferramental do ArcGis que gera automaticamente as classes de declividade.
} 


\subsubsection{Carta de Orientação das vertentes.}

A carta de orientação das vertentes produzida a partir do modelo 3D no ArcGis apresenta nove categorias diferentes de cores e orientações, sendo elas: Plano, Norte, Nordeste, Noroeste, Leste, Sudeste, Sudoeste, Sul e Oeste.

Todas as categorias são representadas com cores diversificadas para que os pontos relevantes sejam representativos e marcantes na visualização da mesma. O processo de elaboração desta carta é o mesmo descrito para as cartas acima, utilizando o 3D analyst, neste caso no formato aspect ${ }^{5}$.

\subsubsection{Carta de Drenagem da área}

A carta de drenagem da área foi elaborada sobre as cartas do IGC a partir da vetorização da drenagem local, identificando-se rios, nascentes, afluentes e sentido do canal. A carta é simples, tendo sido gerada para auxílio no desenvolvimento da pesquisa, focando nas informações discutidas ao longo do trabalho sobre a importância e as influências sobre a drenagem.

\subsubsection{Carta de compartimentação do relevo}

Para elaborar a carta de compartimentação do relevo utilizou-se a carta hipsométrica como base principal, a fim de que se compreendessem os diferentes níveis de relevo encontrados na área de pesquisa. A delimitação e o recorte do

\footnotetext{
${ }^{5}$ Face Aspect with graduated color ramp.
} 
estudo não respeitou o limite da bacia hidrográfica, mas um quadrante específico para a produção do trabalho, centrado no cotovelo da captura fluvial.

A compartimentação está delimitada em três áreas, respeitando-se, principalmente, as diferenças de relevo. As três categorias de compartimentação são:

I. Áreas de topo e parte do trecho compreendido pelo interflúvio entre o rio Guaratuba e o rio Claro - Planalto;

II. Patamar que engloba praticamente todo o leito do Alto rio Guaratuba nas altitudes aproximadas de 820 - 900 metros - Planície do Alto rio Guaratuba;

III. Bordas do anfiteatro e o anfiteatro da Serra do Mar voltado para o Litoral de Bertioga - Bordas da escarpa e Escarpa;

\subsubsection{Trabalho de campo e seleção dos pontos de coleta}

Previamente às atividades de campo e seleção dos pontos de coleta houve a elaboração dos mapas temáticos para que pudessem favorecer e apoiar a interpretação e a escolha dos pontos.

Foram realizadas atividades de campo com o intuito de reconhecimento da área, assim como identificação de pontos potenciais para coleta de amostras. $\mathrm{O}$ trabalho de campo foi realizado em duas etapas. A seleção dos pontos partiu do pressuposto que as amostras coletadas deveriam ser suficientemente representativas e que pudessem informar a característica geral da área.

Os pontos foram selecionados principalmente de acordo com a proximidade das áreas de interflúvio, próximas ao vale seco, para que fosse identificado o local aproximado da captura e para que os dados avaliados pudessem 
identificar a evolução da drenagem ao longo do tempo na área de planalto na Serra do Mar. O segundo critério utilizado para a escolha dos pontos foi o de coletar os dados em locais que estivessem compreendidos nos patamares da compartimentação do relevo proposto (4.2.2.5). 
Figura 4.2-1 - Mapa de Localização dos pontos de coleta.

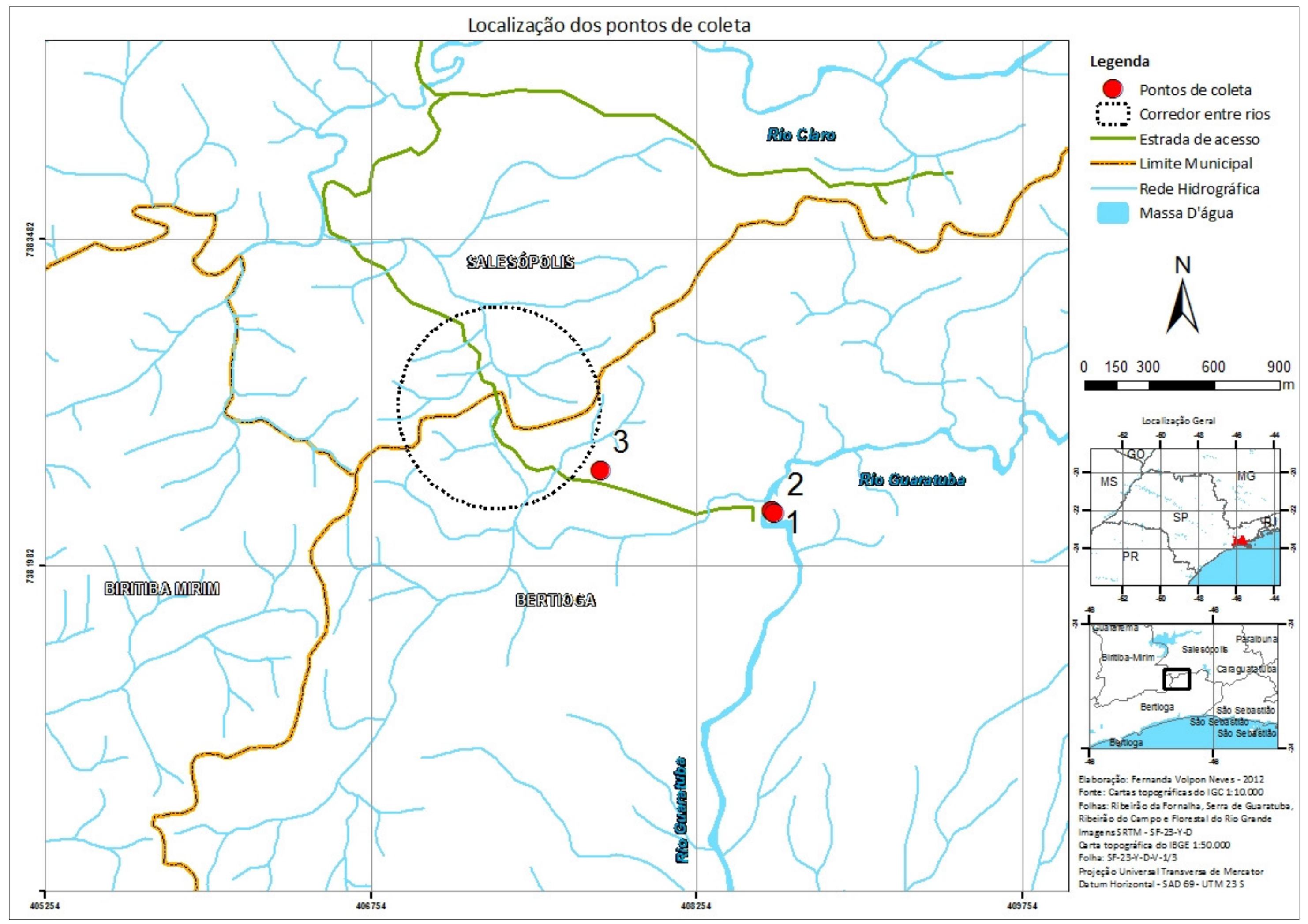




\subsubsection{Coleta das amostras}

As coletas de materiais foram realizadas com o auxílio de toda a equipe em campo. As amostras foram manuseadas por colaborador único, para que se mantivesse a qualidade e padronização da coleta. A equipe auxiliou na chegada à área da coleta, pois o local da pesquisa e coleta das amostras tem pontos de difícil acesso. Também tiveram participação na identificação e descrição dos perfis de solo.

Para a coleta das amostras foram necessários alguns materiais como (Foto 4.2-1):

- Tubos de alumínio de 20 centímetros e uma polegada de diâmetro;

- Marreta de borracha;

- Saco preto de plástico;

- Fita crepe ou Esparadrapo;

- Trena;

- Machadinha e Enxadão;

- Bússola e GPS. 
Foto 4.2-1 - Material utilizado na coleta.

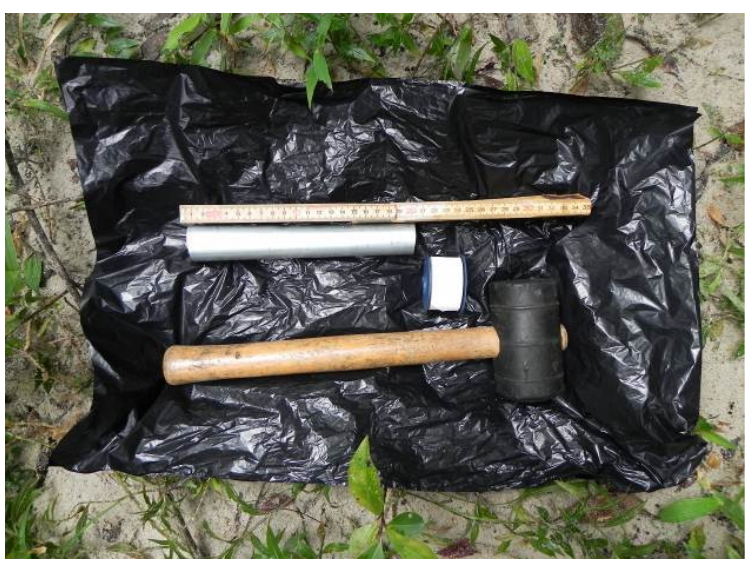

Fotografia de: Déborah de Oliveira. UTM: 408605/ 7382235
Foto 4.2-2 - Inserindo tubo de alumínio na trincheira para coleta do material.

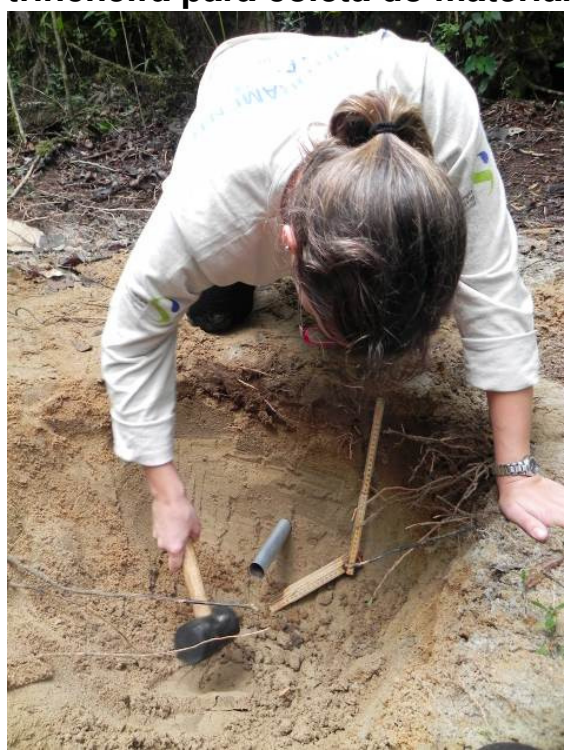

Fotografia de: Déborah de Oliveira. UTM: 408605/ 7382235

As amostras foram coletadas preferencialmente em barrancos ou trincheiras (Foto 4.2-2). Nos dois primeiros pontos de coleta foram abertas trincheiras, para que a coleta fosse de melhor qualidade. O local escolhido para as coletas de números 01 (um) e 02 (dois) está situado no lado oposto de onde se encontra a área de captação da adutora. Neste ponto é possível encontrar muitos materiais depositados, pois é um local característico de deposição do rio.

As amostras foram coletadas e embaladas (Foto 4.2-3 e Foto 4.2-4) uma a uma em sacos de plástico preto. Foram georreferenciadas e delas se extraiu a orientação da coleta, ou seja, sua posição em relação ao norte. 
Foto 4.2-3 - Armazenamento da amostra.

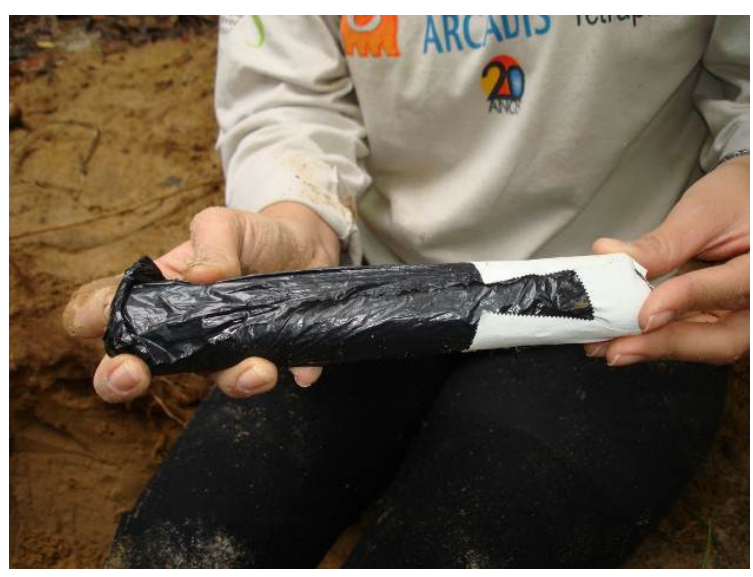

Fotografia de: Natália Nunes de Oliveira UTM: 408605/ 7382235
Foto 4.2-4 - Inserção do tubo para coleta da amostra.

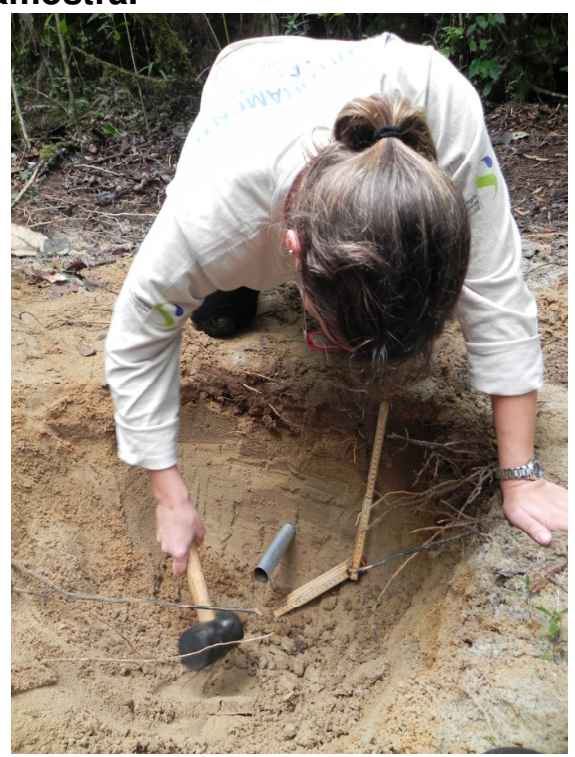

Fotografia de: Déborah de Oliveira UTM: 408605/ 7382235

Apenas em três pontos coletaram-se amostras. Em cada ponto duas coletas. A coleta nesses três pontos iniciais foi realizada com o intuito de se testar a técnica de datação que viria a ser empregada, para que posteriormente fosse realizadas as demais coletas.

As amostras coletadas foram levadas à FATEC $^{6}$ para que as primeiras análises fossem feitas. Os resultados obtidos serão apresentados no item abaixo 5.3.

\subsubsection{Pontos de coleta e descrição das amostras}

\footnotetext{
${ }^{6}$ Faculdade de Tecnologia de São Paulo. Trabalhos realizados no laboratório de Vidro e Datação
} 
Coleta da Amostra 1: 408605/ 7382235

A coleta no ponto 01 foi realizada a $40 \mathrm{~cm}$ de profundidade (Foto $4.2-5$ ). Foi feita uma trincheira e duas amostras foram coletadas paralelamente, (P1A1 e P2A2) distantes entre si cerca de $10 \mathrm{~cm}$ (Foto 4.2-6). Previamente coletou-se uma amostra com distância aproximada de $20 \mathrm{~cm}$ que foi desperdiçada. Optou-se por realizar a segunda coleta mais próxima da amostra de número 01 para que se evitasse a contaminação da mesma.

Foto 4.2-5 - Profundidade de perfil.

Foto 4.2-6 - Medidas entre as amostras

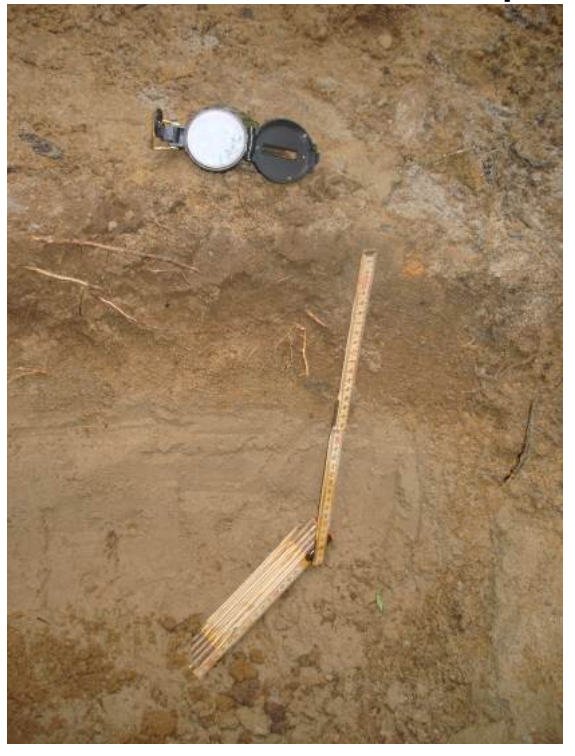

Fotografia de: Natália Nunes de Fotografia de: Natália Nunes de Oliveira Oliveira UTM: $408605 / 7382235$

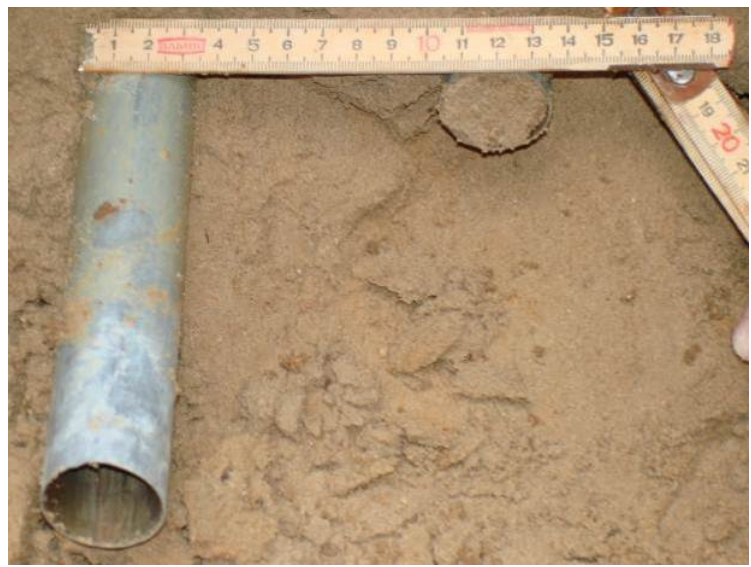

UTM: 408605/ 7382235

Nas amostras tomou-se o cuidado de preservar as informações de frente e fundo dos tubos, pois para as análises, identificar qual a posição do tubo em relação à vertente é importante, uma vez que a parte frontal da amostra está exposta à luz desde o início da abertura da trincheira. 
Para indicar a posição e orientação da amostra em relação ao local de coleta foram extraídas medidas em graus. Nas duas amostras do ponto de coleta 01 a posição dos tubos estava em relação ao norte a: Amostra $\mathrm{P} 1 \mathrm{~A} 1: 330^{\circ}$ graus (frente) e $150^{\circ}$ graus (fundo); Amostra P1A2: $360^{\circ}$ graus (frente) e $180^{\circ}$ graus (fundo).

Apenas três horizontes (Tabela 4.2-1) foram descritos neste perfil, sendo que as cores variaram entre bruno e bruno amarelado. As transições foram todas caracterizadas como abruptas e onduladas.

Tabela 4.2-1 - Horizontes de solo do ponto de coleta 1

\section{Horizonte 1 - (0 a $8 \mathrm{~cm})$}

Cor: 10YR 4/3-Bruno

Textura: Areno-argilosa

Estrutura: Granular

Porosidade: Biológica

Consistência

Seco: macia

Úmido: friável

Molhada

Plasticidade: não plástica

Pegajosidade: não pegajosa

\section{Horizonte 2 - (8 a $19 \mathrm{~cm})$}

Cor: 10YR 5/4 - Bruno Amarelado

Textura: Arenosa

Estrutura: Granular

Porosidade: Pouco Biológica

Consistência

Seco: Solta

Úmido: Solta

Molhada

Plasticidade: não plástica

Pegajosidade: não pegajosa

\section{Horizonte 3 - $(18 \mathrm{~cm}+)$}

Cor: 10YR 5/3 - Bruno

Textura: Areno-siltoso

Estrutura: Maciça tendendo a bloco sub-angular

Porosidade: Poucos poros e muito pequenos

Consistência

Seco: ligeiramente duro

Úmido: friável

Molhada

Plasticidade: ligeiramente plástica

Pegajosidade: não pegajosa 
As categorias acima elencadas obedecem ao manual de descrição e coleta de campo de Santos et al (2005), levando-se em consideração que as frações são estimadas em campo pelas sensações táteis podendo dar diferença entre as pessoas que analisarem uma mesma amostra.

\section{Coleta da Amostra 2: 408616/ 7382224}

No ponto dois a coleta foi realizada a $50 \mathrm{~cm}$ de profundidade (Foto 4.2-7). Uma trincheira foi cavada para a coleta das duas amostras (P2A1 e P2A2) paralelas distantes entre si cerca de $20 \mathrm{~cm}$. Nestas duas amostras as medidas em graus da posição dos tubos em relação ao norte são: Amostra 1: $270^{\circ}$ graus (frente) e $90^{\circ}$ graus (fundo); Amostra 2: $250^{\circ}$ graus (frente) e $70^{\circ}$ graus (fundo).

Na descrição deste perfil (Tabela 4.2-2 e Foto 4.2-8) foram encontrados apenas dois horizontes, sendo que as cores variaram entre bruno amarelado escuro e bruno amarelado. A transição entre eles foi considerada abrupta e ondulada.

A amostra dois apresenta em sua consistência úmida um material extremamente friável. De acordo com Santos (2005) este comportamento tem a seguinte característica: "o material do solo esboroa-se com pressão muito leve, mas agrega-se por compressão posterior".

\section{Tabela 4.2-2 - Horizontes de solo do ponto de coleta 2}

\section{Horizonte 1 - (0 a $16 \mathrm{~cm})$}

Cor: 10YR 4/4 - Bruno Amarelado Escuro Arenoso

Textura: Arenosa

Estrutura: Blocos sub-angulares tendendo a granular

Porosidade: Pouca porosidade biológica

Consistência

Seco: macia

Úmido: muito friável

Molhada

Plasticidade: ligeiramente plástica

Pegajosidade: não pegajosa 


\section{Horizonte 2 - $(16 \mathrm{~cm} \mathrm{a}+)$}

Cor: 10YR 5/6 - Bruno Amarelado

Textura: Arenosa

Estrutura: Sub-angular tendendo a maciça

Porosidade: Poucos poros

Consistência

Seco: macia

Úmido: muito friável

Molhada

Plasticidade: não plástica

Pegajosidade: não pegajosa

Foto 4.2-7 - Coleta das amostras a $50 \mathrm{~cm}$.

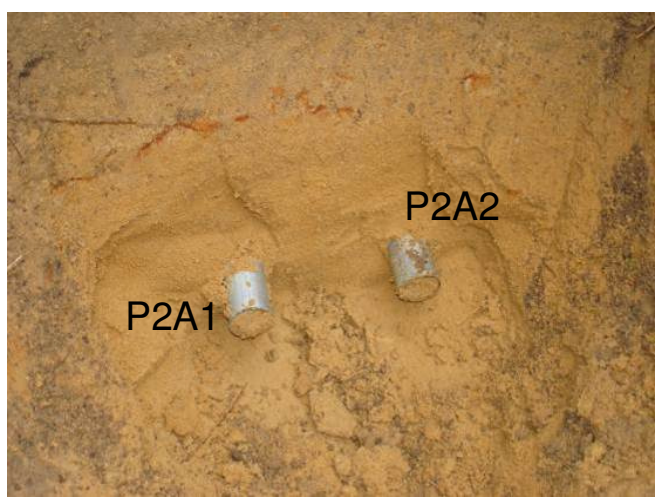

Fotografia de: Natália Nunes de Oliveira. UTM: 408616/ 7382224
Foto 4.2-8 - Perfil de solo descrito em campo.

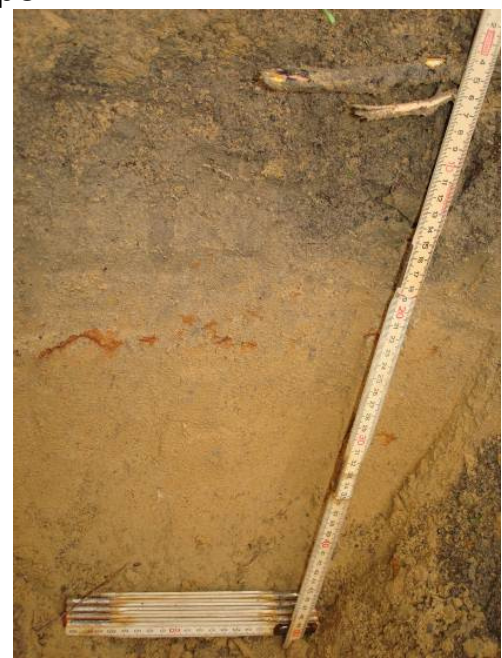

Fotografia de: Natália Nunes de Oliveira. UTM: 408616/ 7382224

Coleta da Amostra 3: 407813/ 7382417

No ponto 03 (três) a coleta de campo foi realizada em dois pontos distantes entre si em profundidade, diferentemente dos dois primeiros pontos de coleta. A primeira amostra (P3A1) foi coletada a $40 \mathrm{~cm}$ de profundidade com angularidade de $180^{\circ}$ graus (frente) e $0^{\circ}$ graus (fundo). A segunda amostra (P3A2) foi coletada a uma profundidade de $80 \mathrm{~cm}$ apresentando angularidade em relação ao 
norte de $180^{\circ}$ graus (frente) e $0^{\circ}$ graus (fundo). Essa segunda amostra (P3A2) está contida em um pacote de solo abaixo da cascalheira descrita, num trecho de material muito úmido, com presença de água. A coleta da mesma foi mais trabalhosa (Foto 4.2-11 e Foto 4.2-12) em razão de estar contida num solo menos denso. Para encher o tubo de material sedimentar foi necessária a inserção do tubo em maior profundidade no barranco.

Esta amostra foi coletada em barranco (Foto 4.2-9 e Foto 4.2-10) na parte externa da estrada de ligação, no bordo lateral da adutora. $O$ barranco tem espessura de aproximadamente $150 \mathrm{~cm}$, é possível observar sua extensão e detalhar seu perfil, encontrando seis categorias diferenciadas de cores e texturas.

$\mathrm{Na}$ descrição deste perfil o mesmo foi subdividido em seis horizontes (Tabela 4.2-3), sendo que o último deles muito parecido com as características originais da rocha. As cores variaram entre Bruno Avermelhado Escuro (no seu topo) passando por Cinza e terminando na sua base com Cinza apresentando manchas vermelhas. As transições foram todas caracterizadas como abruptas e onduladas.

\section{Tabela 4.2-3 - Horizontes de solo do ponto de coleta 3}

\section{Horizonte 1 - (0 a $5 \mathrm{~cm})$}

Cor: 5YR 3/3 - Bruno Avermelhado Escuro

Textura: Argilosa

Estrutura: Grumosa

Porosidade: Biológica forte

Consistência

Seco: ligeiramente dura

Úmido: muito friável

Molhada

Plasticidade: não plástica

Pegajosidade: não pegajosa

Horizonte 2 - (5 a $16 \mathrm{~cm})$

Cor: 7,5YR 4/6 - Bruno Forte

Textura: Argilosa

Estrutura: Blocos sub-angulares

Porosidade: Biológica forte 


\begin{tabular}{|c|c|}
\hline \multirow{2}{*}{ Consistência } & Seco: ligeiramente dura \\
\hline & Úmido: friável \\
\hline \multirow{2}{*}{ Molhada } & Plasticidade: plástica \\
\hline & Pegajosidade: ligeiramente pegajosa \\
\hline & Horizonte 3 - ( 16 a $70 \mathrm{~cm}$ ) - Cascalheira \\
\hline
\end{tabular}

Cor: 7,5YR 5/1 - Gray (cinza)

Textura: Arenosa com cascalhos sub-angulares centimétricos $(\sim 2 \mathrm{~cm})$

Estrutura: Granular

Porosidade: Intersticial

$\begin{array}{ll}\text { Consistência Seco: não determinado - verte água } & \text { Úmido: solto }\end{array}$

Molhada

Plasticidade: não plástica

Pegajosidade: não pegajosa

\section{Horizonte 4 - ( 70 a $90 \mathrm{~cm}$ )}

Cor: 5YR 3/2 - Bruno avermelhado escuro

Textura: Argilosa

Estrutura: Maciça

Porosidade: Sem poros visíveis

Consistência Seco: ligeiramente duro
Úmido: firme

\begin{tabular}{l|l} 
Molhada & Plasticidade: plástica \\
\hline & Pegajosidade: ligeiramente pegajosa
\end{tabular}

Horizonte 5 - ( 90 a $115 \mathrm{~cm})$

Cor: Matriz: 7,5YR 6/8 - Amarelo-avermelhado. Manchas: 2,5YR 4/8 - Vermelho

Textura: Argilo-arenosa

Estrutura: Maciça

Porosidade: Sem poros visíveis

Consistência Seco: ligeiramente duro

Úmido: firme

Molhada

Plasticidade: ligeiramente plástica

Pegajosidade: ligeiramente pegajosa

\section{Horizonte 6 - ( $115 \mathrm{~cm} \mathrm{a} \mathrm{+)}$}

Cor: Matriz: 7,5YR 6/1 - Gray com manchas milimétricas vermelhas

Textura: Silto arenoso

Estrutura: Maciça

Porosidade: Sem poros visíveis

Consistência Seco: ligeiramente duro

Úmido: muito friável

Molhada

Plasticidade: ligeiramente plástica

Pegajosidade: não pegajosa 
Foto 4.2-9 - Perfil 3.

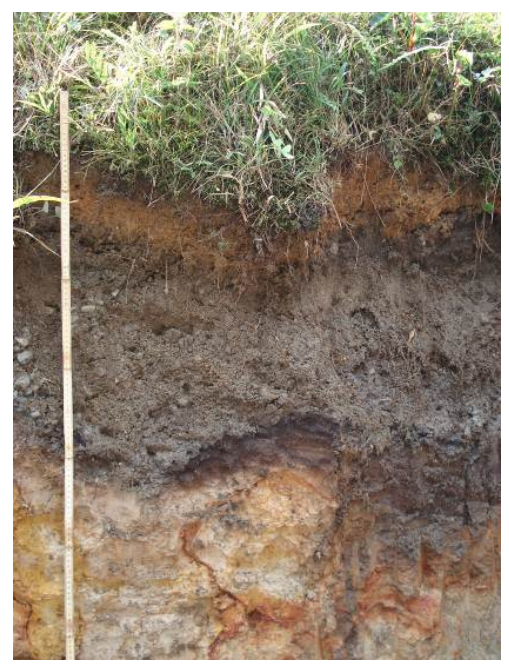

Fotografia de: Fernanda Volpon Neves UTM: $407813 / 7382417$

\section{Foto 4.2-11 - Remoção da amostra P3A2 do barranco.}

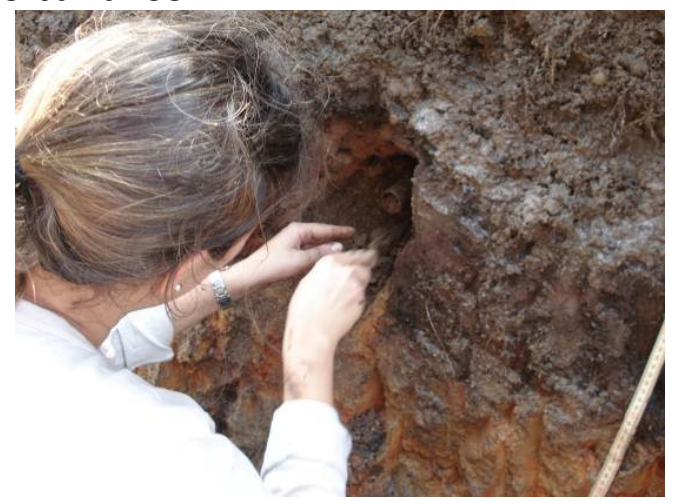

Fotografia de: Fernanda Volpon Neves UTM: $407813 / 7382417$
Foto 4.2-10 - Amostra P3A1 do barranco a $40 \mathrm{~cm}$.

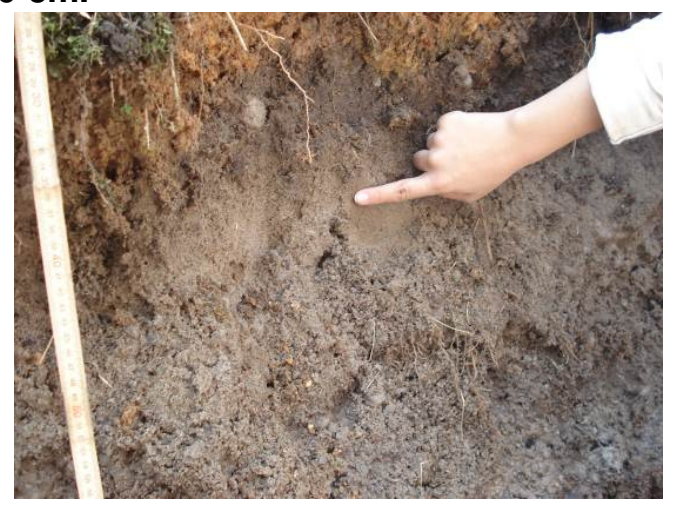

Fotografia de: Fernanda Volpon Neves UTM: 407813/ 7382417

\section{Foto 4.2-12 - Cascalheira encontrada no barranco.}

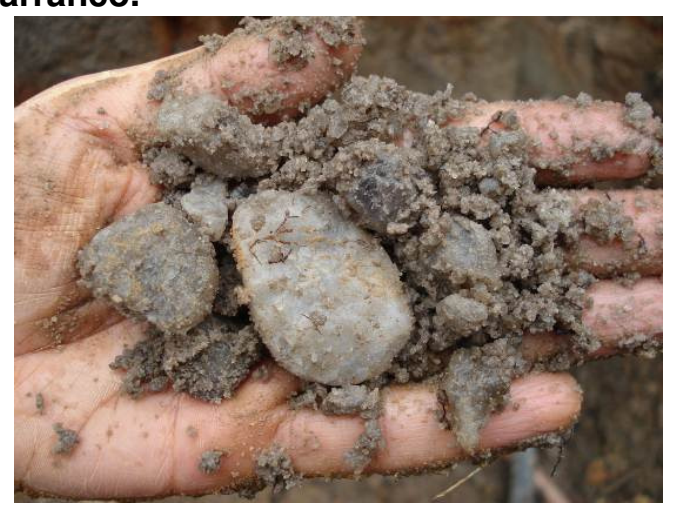

Fotografia de: Fernanda Volpon Neves UTM: 407813/ 7382417

$\mathrm{Na}$ terceira amostra foram identificadas algumas categorias não observadas anteriormente nas amostras um e dois. A estrutura apresentou característica grumosa ("quando as unidades estruturais são muito porosas"). Na amostra úmida o material apresenta característica firme Quanto a plasticidade no 
horizonte quatro a amostra se apresentou plástica e consequentemente ligeiramente pegajosa. (SANTOS, 2005).

\subsubsection{Luminescência oticamente estimulada (LOE)}

A utilização de técnicas de datação por Luminescência Oticamente Estimulada (LOE) para a compreensão da evolução da drenagem no quadrante compreendido pelo trecho da captura fluvial terá uma grande contribuição na interpretação de sua evolução, analisando as formas e vestígios como as cascalheiras apresentadas por Rossi (1999) e Oliveira (2003).

Visando a busca pelo canal fluvial antigo, do rio Guaratuba, a fim de compreender e elucidar de forma mais precisa as mudanças ocorridas no canal, se utilizou esta técnica moderna de datação de sedimentos para as amostras coletadas em campo.

A LOE é uma técnica que utiliza aparelhos que chegaram ao Brasil somente em 2011. A vantagem de se trabalhar com este equipamento é a escala de riqueza nos detalhes e precisão nos resultados que 0 leitor $\mathrm{RISO}^{7}$ pode proporcionar. Toda técnica de laboratório requer acuidade e certa destreza no manuseio dos materiais, exigindo dedicação para que se obtenham os resultados sobre as amostras coletadas em campo.

A partir do retorno do campo e a fim de estabelecer uma mesma técnica para todos os pontos de coleta de material, estabeleceu-se que o quartzo seria 0 grão a ser trabalhado, uma vez que o material apresentava características grosseiras, sendo que, para a extração de feldspato demandaria uma quantidade

\footnotetext{
${ }^{7}$ RISO TL/OSL READER MODEL DA-20 - Máquina Dinamarquesa.
} 
ainda maior de material (em massa) para chegar a uma parcela mínima de amostra limpa para datação por LOE. A chance de se encontrar feldspato é muito menor se comparada à quantidade de quartzo disponível na composição do solo da área de pesquisa, baseado na composição das rochas da Serra do Mar. A partir do momento da certeza de se trabalhar com o quartzo, considerou-se, o quartzo, mineral dosímetro, até o final das análises das amostras.

Para datar as amostras de quartzo extraídas do material coletado em campo, foi utilizada em LOE as LED que emitem sobre a alíquota da amostra luz azul de 470 nanômetros (nm), e provoca a emissão da luz Ultra-violeta, como resposta à incidência. Caso a datação fosse realizada em partículas de feldspato seria utilizado IRSL (Infra Red Stimulated Luminescence), sendo que a diferença entre eles é a forma de estimulação e detecção.

Segundo Cunha (2010) as datações por LOE são muito mais confiáveis do que por TL (termoluminescência), pois, o sinal luminescente emitido pela estimulação LOE produz uma luz mais rápida e eficazmente limpa.

Para medir a dose equivalente das amostras, é possível aplicar dois protocolos sendo eles: alíquotas múltiplas $\left(\mathrm{MAR}^{8}\right)$ ou de alíquota única $\left(\mathrm{SAR}^{9}\right)$. $\mathrm{O}$ protocolo utilizado nesta técnica foi o de SAR, sendo que a Dose Equivalente é obtida através do comportamento individual de cada prato (Foto 4.2-19) de quartzo, em que a dose equivalente é determinada utilizando uma gama de doses que englobam a dose singular (WALLINGA et al, 2000).

\footnotetext{
${ }^{8}$ Multiple-aliquot regenerative-dose

${ }^{9}$ Single-liquot regenerative-dose
} 


\subsubsection{Separação da amostra}

Foram coletadas em campo seis amostras (três pontos de coleta) em áreas de trincheiras e barrancos, objetivando a realização de análises por LOE. As amostras coletadas em campo foram armazenadas cumprindo o procedimento de mantê-las o mais protegida possível da exposição solar, ou de qualquer tipo de luz presente no ambiente.

A partir da amostra coletada pode-se dividir uma mesma amostra em três diferentes porções para que fosse possível trabalhar com as partes de diferentes formas, cada uma com um objetivo, obtendo assim a Dose equivalente da amostra. A partir da identificação de cada amostra em laboratório se iniciaram os procedimentos de separação e secagem do material. De todos os tubos das amostras utilizou-se praticamente a totalidade do material coletado em campo para cada.

De cada tubo coletado, dos três pontos de coleta diferentes, desprezou-se da amostra apenas as partes mais externas, que não tem utilidade para a LOE, uma vez que tiveram contato com a luz. A partir do momento que há o contato com a luz o mineral de quartzo inicia a liberação de energia, zerando a idade armazenada da amostra.

Na Figura 4.2-2, é possível identificar as partes a serem utilizadas na datação. O material nomeado como "usado para Dose Anual", é uma parcela da amostra coletada que se extrai do material que não será utilizado para a produção da amostra pura. 
Figura 4.2-2 - Esquema do tubo de coleta de campo e a divisão do material coletado.

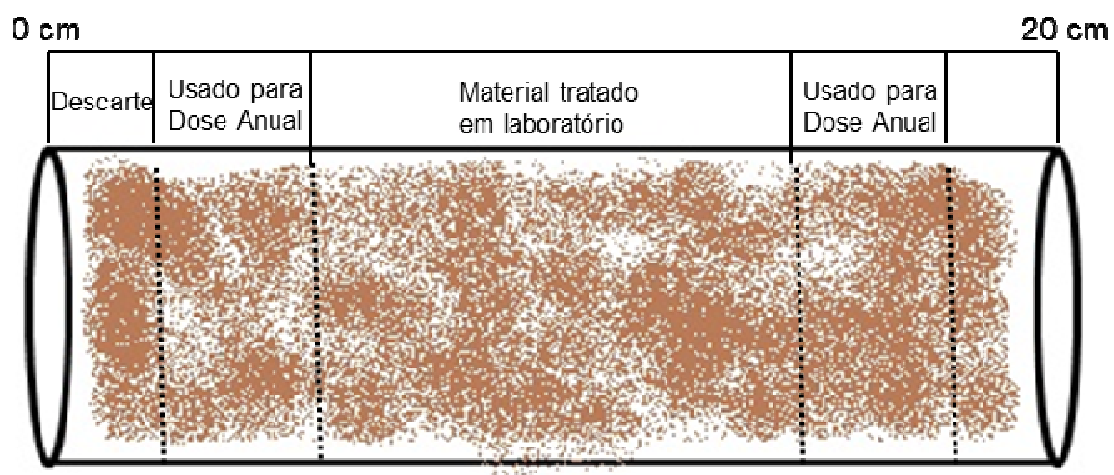

Elaborado por: Fernanda Volpon Neves, 2012

A amostra que havia sido separada para a realização da dosagem anual passou por processo de secagem em estufa para que resultasse em um material friável, seco e de massa real (umidade removida). Para a correção da umidade presente na amostra uma pequena parcela deste material (cerca de 5 gramas por amostra), foi colocada num equipamento específico e foi aplicada a termogravimetria. Conforme há o aquecimento e remoção da idade, obtém-se uma massa mais leve e seca se comparada com a massa inicial da amostra. Sendo assim, é possível extrair a porcentagem de umidade contida na amostra de solo.

A amostra que foi seca na estufa será utilizada para extração dos dados resultantes da contagem que o detector de radiação fará sobre os elementos presentes no material coletado. As contagens de radiação liberada por essa amostra (cerca de 100 gramas de amostra) é chamada de taxa de radiação ambiental (dose anual) (CUNHA, 2010). Para se alcançar a idade real da amostra, deve-se dividir a Dose Equivalente (Paleodose) / Dose anual (Taxa de radiação ambiental). 


\subsubsection{Desenvolvimento em laboratório}

\section{A) Material e equipamentos}

Para o manuseio e manipulação das amostras em laboratório para a obtenção do material puro para a datação por LOE (através do leitor RISO) utilizouse o laboratório de vidros e Datação da FATEC onde há todos os equipamentos para limpeza das amostras, além de uma sala específica onde está localizado o leitor RISO.

Os materiais e equipamentos utilizados em laboratório são (Foto 4.2-13):

- Peneiras de 75 e 150 um (micrômetro).

- Potes plásticos para manuseio de produtos químicos,

- Tubos de filme fotográfico,

- Papel alumínio,

- Capela para manusear produtos químicos (Foto 4.2-15),

- Estufa para remoção da umidade da amostra/ secagem do material,

- Funil,

- Destilador de água,

- Peróxido de Hidrogênio (H2O2) Ácido Fluorídrico (HF), Ácido Clorídrico (HCL), Água destilada,

- Ímã, pinça, cotonete, álcool, pincel,

- Daybreak 1100 para medir LOE/TL;

- Balança de Precisão,

- Leitor RISO (Foto 4.2-16), 
Foto 4.2-13 - Alguns materiais utilizados para selecionar e organizar as amostras na RISO

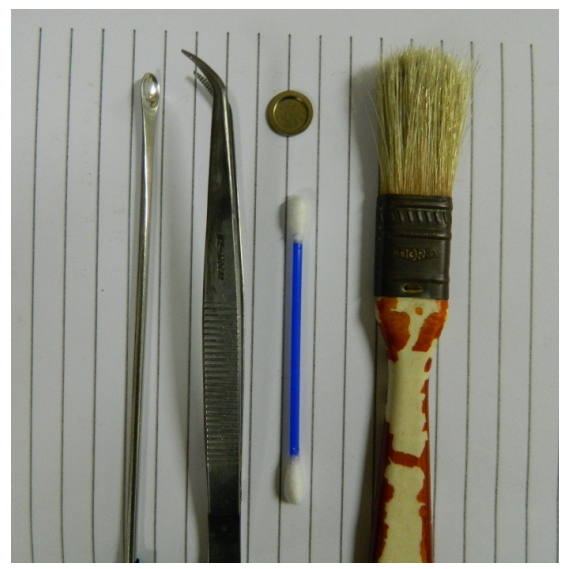

Fotografia de: Fernanda Volpon Neves, 2011

Foto 4.2-15 - Capela para manuseio dos produtos químicos. Ao fundo à direita máquina de destilação de água

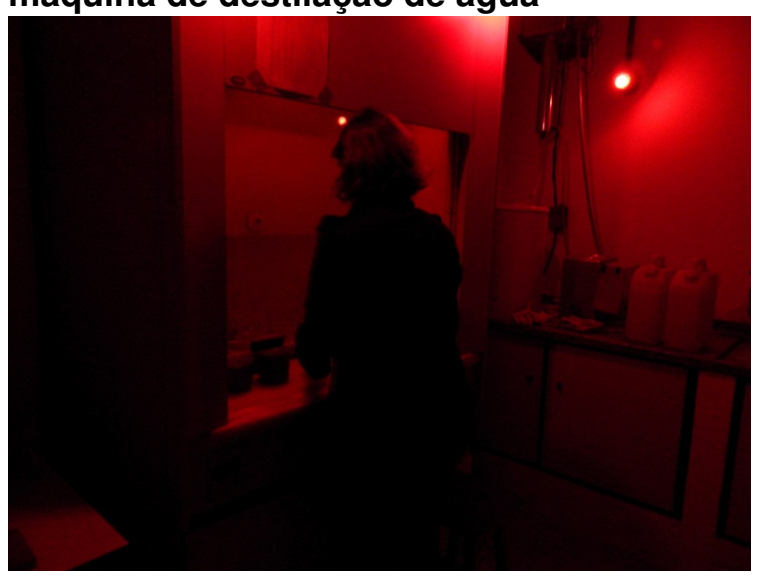

Fotografia de: Fernanda Volpon Neves, 2011.
Foto 4.2-14 - Material preparado para dose equivalente e dosagem ambiental

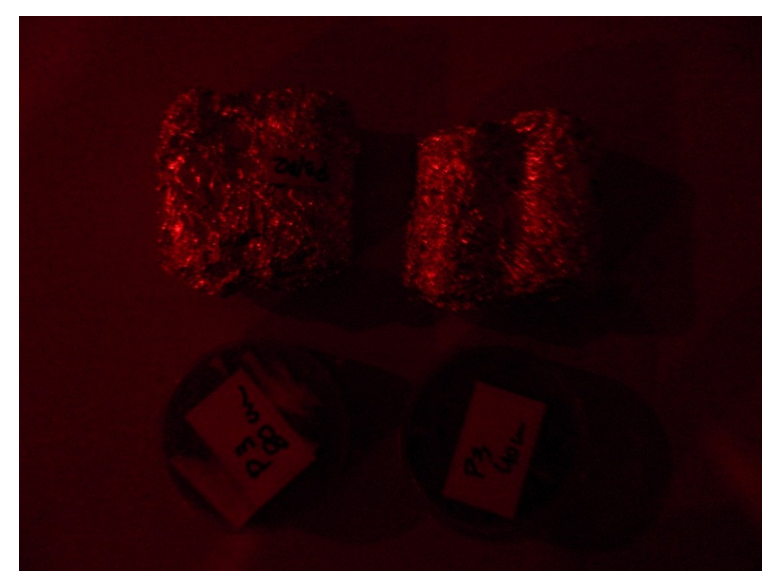

Fotografia de: Fernanda Volpon Neves, 2011

Foto 4.2-16 - Máquina RISO (à direita) Medidor de radiação (à esquerda da foto).

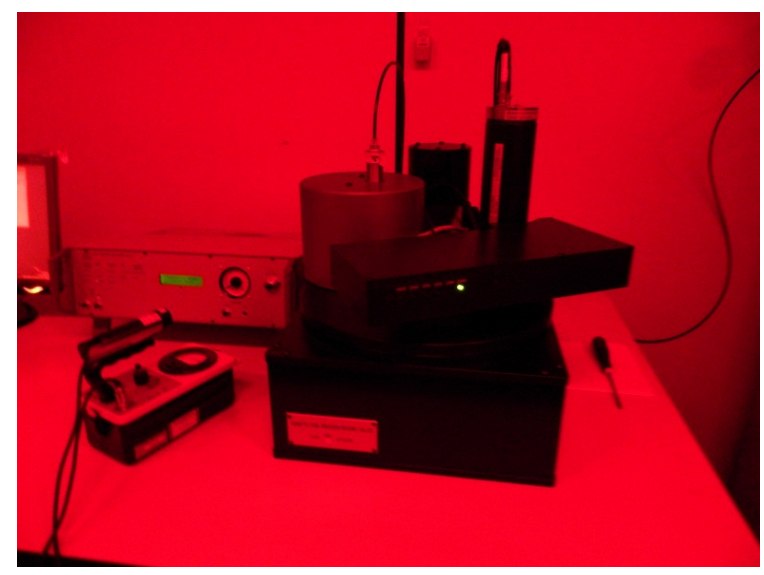

Fotografia de: Fernanda Volpon Neves, 2011.

\section{B) Limpeza das amostras}

Para obtenção das amostras de solo consideradas puras a serem trabalhadas em laboratório foi preciso que o material coletado em campo passasse por um processo de limpeza química das impurezas. A resultante dessa limpeza são grãos de quartzo transparentes utilizados em análise no leitor RISO. 
Toda a descrição a seguir faz parte das atividades desenvolvidas em laboratório em sala com câmara escura para que a amostra não sofra nenhuma alteração ou exposição à luz, pois, a exposição à luz poderia provocar alteração na Dose equivalente da amostra.

O material coletado em campo passa por diversas etapas de limpeza para a obtenção do material puro a ser utilizado para extração da Dose equivalente sendo elas:

1. Peneiramento de parte da amostra com malha de espessura aproximada de 75 e $150 \mu \mathrm{m}$ (os grãos peneirados ficaram entre as peneiras citadas).

2. Se a amostra coletada em campo apresentar em sua composição material orgânico o primeiro passo é remover este material orgânico com Peróxido de Hidrogênio a 34\%.

3. Se o material não contém material orgânico ele é trabalhado diretamente com Ácido Fluorídrico (HF) a $24 \%$ onde o material fica em repouso por cerca de 1 1 1 2 horas para a remoção de tudo o que não for mineral de quartzo, além de remover uma fina camada de quartzo,

4. Enxaguar o material com água destilada,

5. Após enxaguar o material colocar em solução de Ácido Clorídrico a 20\%, por aproximadamente 2 horas, para remoção dos últimos grãos de Feldspato (material mais fino do que o quartzo), eliminando também possíveis fluoretos que tenham sido formados no processo anterior,

6. Enxaguar bem o material com água destilada,

7. Por último, passar o ímã sobre o material puro para remover os últimos grãos metálicos que possam ter ficado presentes na amostra. 
Folz et al (2001) seguem este protocolo de limpeza da amostra em laboratório para datação pela técnica de LOE que consistem em grãos de areia de tamanhos pequenos e finas partículas de argila. As partículas obedecem ao mesmo padrão empregado na pesquisa, sendo as amostras tratadas com Ácido Clorídrico ( $\mathrm{HCL})$, Peróxido de Hidrogênio $\left(\mathrm{H}_{2} \mathrm{O}_{2}\right)$ e peneiramento dos grãos grosseiros de quartzo (200 - 250 m de diâmetro) antes da remoção dos minerais pela separação por densidade. Os grãos são finalmente preservados em $40 \%$ de Ácido Fluorídrico (HF) por 50 minutos e a ausência de contaminação de feldspato é verificada usando IRSL após uma irradiação de laboratório e de pré-aquecimento.

Durante o processo de limpeza da amostra e remoção das impurezas, outras atividades paralelas têm de ser desenvolvidas, tais como: secagem do material para detecção dos espectros da radiação-gama para obtenção da dose anual; teste de parte do material puro na Daybreak para estimar o tempo de irradiação que cada amostra precisa para ser utilizada no leitor RISO; cálculo da umidade da amostra através de termogravimetria; dentre outros testes e preenchimento de tabelas auxiliares ${ }^{10}$.

\section{C) Secagem das amostras e obtenção da massa seca}

A amostra, que foi separada para ser utilizada no aparelho que mede a taxa de umidade do material (através da termogravimetria), é colocada em pequenos pratos de forma tal que toda a amostra fique distribuída uniformemente neste prato a

\footnotetext{
10 Todas as tabelas relativas à calibração da dose equivalente foram fornecidas pela equipe do laboratório de Vidros e Datação da FATEC/SP
} 
fim de que todo o calor recebido na amostra possa ser distribuído por igual na amostra, a fim de obter resultado mais rápido da remoção da umidade.

Os resultados de perda da umidade são gerados em gramas sendo que a perda de umidade da amostra de acordo com a massa inicial menos a massa final torna possível calcular em porcentagem o valor da umidade por amostra

As amostras utilizadas para o cálculo da taxa de umidade tinham sua massa inicial variando entre 6,8 gramas e 6,075 gramas. A porcentagem de perda de umidade das amostras variou entre $31,12 \%$ a $7,24 \%$ para as amostras P3A2 e P3A1 respectivamente, sendo estas as mais altas dentre todas as amostras.

Como é possível observar no Gráfico abaixo a amostra P3A2 demandou mais tempo do que as demais amostras para obter o seu ponto mais seco. Provavelmente, a amostra apresenta em sua estrutura material mais compactado que as demais áreas, além de massa mais densa.

Gráfico 4.2-1 - Perda de umidade das amostras.

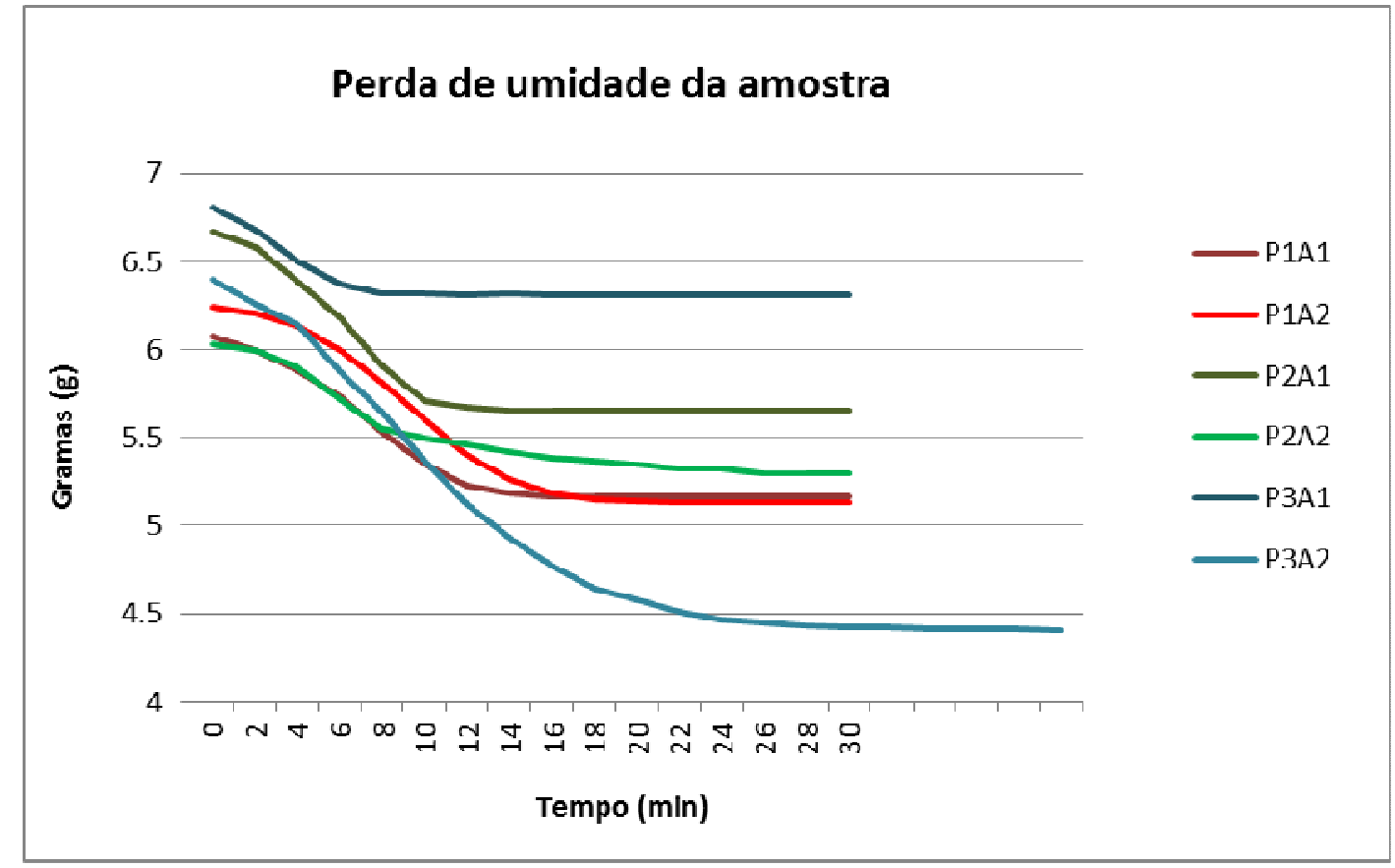

Elaborado por: Fernanda Volpon Neves, 2012. 
O cálculo da umidade é realizado para que se faça uma correção nos valores da taxa da Dose Anual das amostras. Utiliza-se uma simples regra de três para extrair a porcentagem de umidade da amostra e para a correção da Dose Anual uma conta simples da massa inicial da amostra subtraída da massa final. A diferença neste cálculo resulta na quantidade de água no solo e de massa seca em gramas. Todos os dados obtidos são transformados em valores para serem inseridos na tabela de calibração da dose, no mesmo campo onde se insere os dados de localização e massa da amostra (Figura 4.2-3).

A água é fundamentalmente importante neste processo, e compreender o quanto de umidade que existe na amostra pode proporcionar seu melhor ajuste, uma vez que a água tem a capacidade de absorver uma parte da radiação emitida pelos elementos radioativos, não bloqueando por completo a passagem pela água, mas diminuindo a quantidade de radiação que deveria atingir o material.

Figura 4.2-3 - Tabela com os dados de localização da amostra e as medidas de massa da amostra (P1A1)

\begin{tabular}{|c|c|}
\hline \multicolumn{2}{|c|}{ Dados de localização e massa da amostra } \\
\hline Profundidade do Sedimento & $40 \mathrm{~cm}$ \\
\hline Latitude Geografica & 23 graus \\
\hline Longitude Geografica & 45 graus \\
\hline Altitude (em relação ao nível do mar) & $7.8 \mathrm{Km}$ \\
\hline Quantidade de água no solo & $0.77 \mathrm{~g}$ \\
\hline Massa do Solo Seca & $59.71 \mathrm{~g}$ \\
\hline Fator F & 0.2 \\
\hline
\end{tabular}

Fornecido por: Laboratório de Vidros e Datação - FATEC/SP ${ }^{11}$

11 Todas as planilhas referentes à datação foram fornecidas pelo Laboratório de Vidros e Datação da

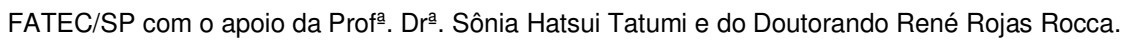




\section{D) Calibração das amostras na Daybreak}

Para dar continuidade no processo de datação, antes das amostras de quartzo serem colocadas no leitor RISO, foi realizado um teste na Daybreak com todas as amostras, para que se extraísse de forma mais aproximada o tempo de irradiação necessário para cada amostra. O comportamento aproximado das amostras seria o parâmetro a ser utilizado na LOE.

O tempo de irradiação aproximada das amostras, é o tempo em que a amostra fica exposta á irradiação que a RISO fará sobre a alíquota, ou seja, não é o tempo de luz incidente, mas sim o tempo que a alíquota é submetida à irradiação que o leitor RISO faz previamente ao aquecimento da amostra.

O leitor RISO é muito mais rápido do que a Daybreak (Foto 4.2-17 e Foto 4.2-18) quando faz as medidas de LOE, no entanto, não havia tempo suficiente para fazer testes na RISO de LOE, por isso utilizou-se a Daybreak para fazer os primeiros testes de LOE para extração dos dados aproximados a serem trabalhados no leitor RISO. Como o processo no leitor RISO ${ }^{12}$ exigiu para cada amostra cerca de $24 \mathrm{~h}$ era preciso saber qual seria a emissão luminescente individual para cada alíquota da amostra, por isso foi necessário neste caso uma valor de referência médio para irradiação das amostras extraídos dos testes realizados na Daybreak.

12 No leitor RISO as amostras demoraram cerca de $24 \mathrm{~h}$ para serem processadas. Foi demandado aproximadamente cinco dias do leitor RISO para obter os dados de todas as amostras. Por mês foi possível agendar a máquina para aproximados dois dias, sendo que todo o trabalho durou cerca de três meses. Essa demora ocorreu, pois, existe apenas esta máquina RISO na FATEC e todas as pessoas interessadas em desenvolver trabalhos de datação por LOE, tem que entrar na fila por espaço, logo o agendamento é longo. No Brasil há outras 3 máquinas (IPEN, IGC-USP, e mais uma outra no instituto de física na área da dosimetria) que são utilizadas para trabalhos com LOE. 
Cada amostra teve um comportamento na Daybreak (teste realizado por LOE), entretanto, todas elas apresentaram uma curva do comportamento de resposta à luminescencia. Foram utilizados sete pratos com amostras de massa similar, podendo ser elaborada a partir dessas sete medidas uma curva média do comportamento das amostras.

\section{Foto 4.2-17 - Separação do material para} teste na $T L$.

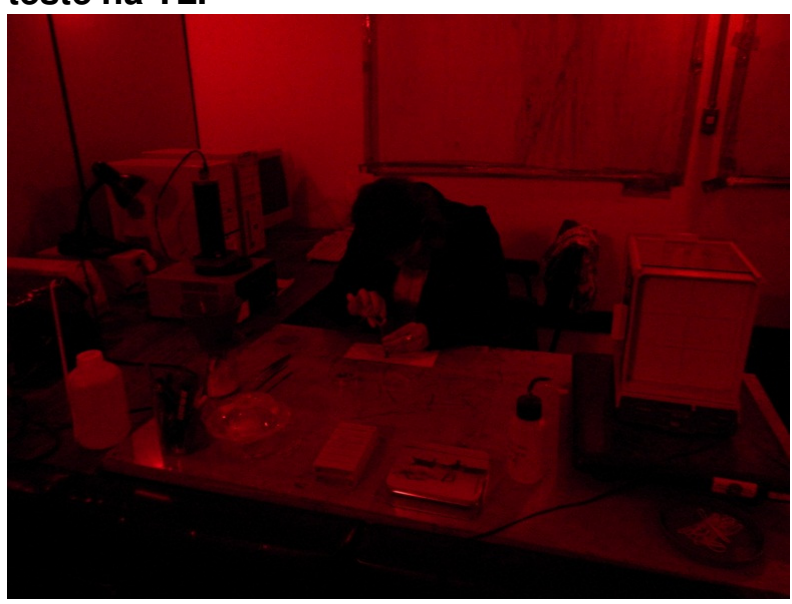

Fotografia de: Fernanda Volpon Neves

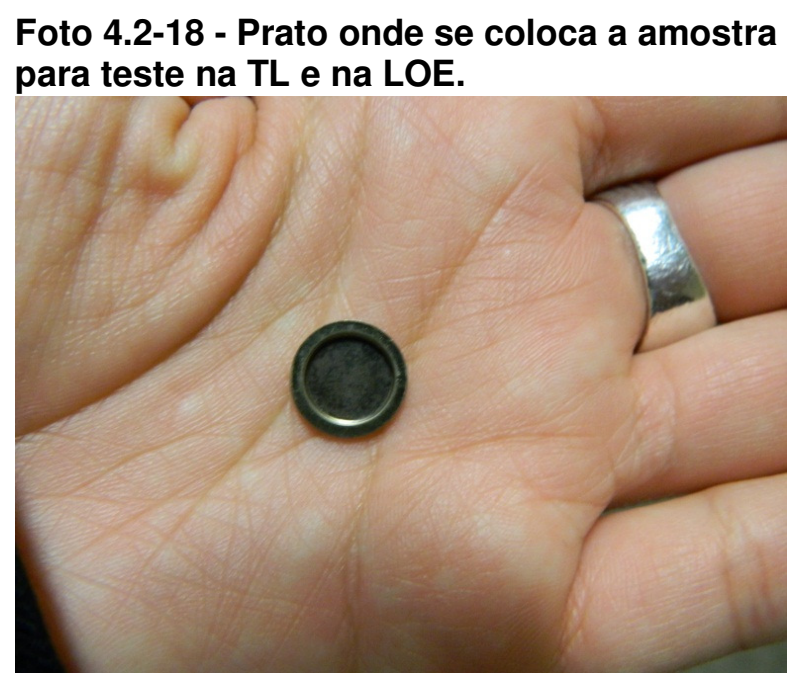

Fotografia de: Fernanda Volpon Neves

Para cada amostra um gráfico (Gráfico 4.2-2) foi gerado com a média da luminescencia das amostras. Isso possibilitou informar os dados obtidos por amostra na Daybreak ao software do leitor RISO. No gráfico abaixo A é o tempo, J é a intensidade de luminescencia que a amostra emitiu. Para compreensão dos dados totais das amostras um gráfico (Gráfico 4.2-3) foi gerado com a média absoluta de todas as amostras. Esses gráficos foram gerados para que auxiliassem na compreensão do comportamento das amostras. Nesta situação, as amostras 1, 2 e 3 apresentaram erros de manuseio e seleção de material muito maiores se comparado com as outras três amostras. 
Gráfico 4.2-2 - Comportamento médio da amostra P1A2 em resposta ao estímulo luminescente na Daybreak

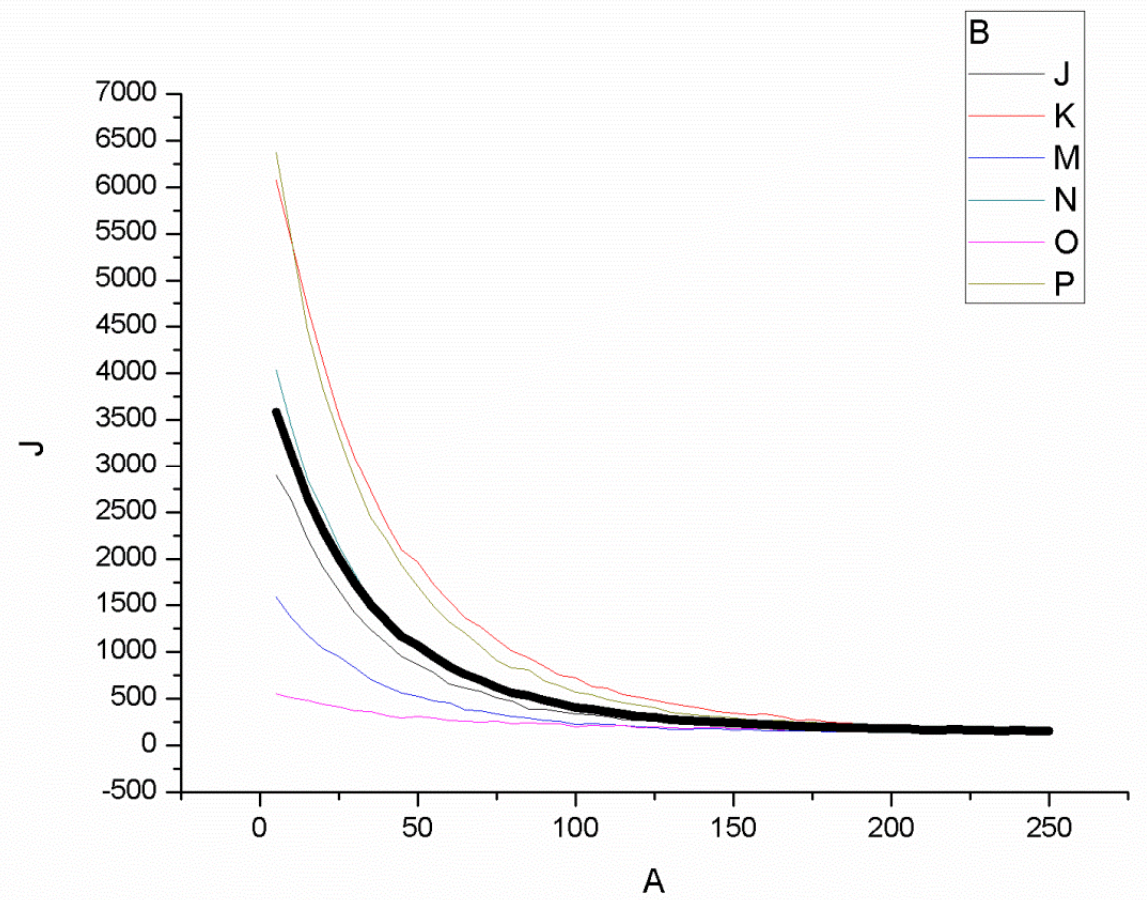

Elaborado por: René Rojas Rocca, 2011

Gráfico 4.2-3 - Cálculo médio do sinal das amostras por estímulo luminescente na Daybreak

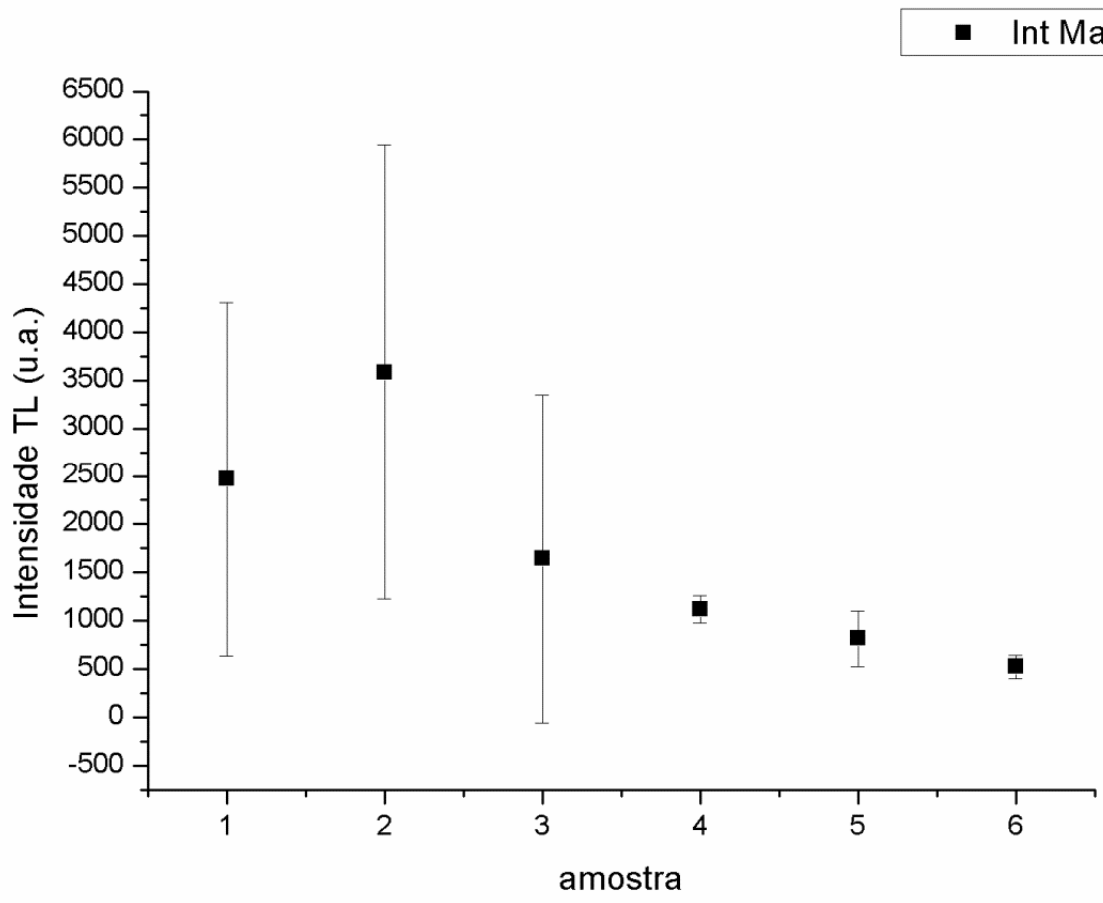

Elaborado por: René Rojas Rocca, 2011 


\section{E) Cálculo das variáveis da dosagem anual de Th, U1, U2 e K}

Ao mesmo tempo em que testes de umidade, na Daybreak e as medidas no leitor LOE ocorreram, foram realizadas as medidas da dose anual das amostras. O material separado desde o início do processo passou pela secagem na estufa para que se tornasse um material friável e seco. A posteriori foi pesado em balança de precisão para se conhecer a massa da amostra seca. Nessa etapa a amostra foi colocada num equipamento que mede o decaimento radioativo da amostra.

Considerando que as amostras dos pontos de coleta um e dois são paralelas entre si (P1A1/ P1A2 e P2A1/ P2A2) foi realizado apenas um cálculo da dose anual para cada um dos conjuntos de amostras, considerando que pela proximidade e semelhança do local não haveria diferença entre as mesmas. Apenas para as amostras P3A1 e P3A2 houve duas medidas distintas para a dose anual. Neste caso as amostras estão a cerca de $40 \mathrm{~cm}$ distantes entre si em profundidade, considerando assim diferentes momentos de deposição do material.

Os valores de decaimento radiativo obtidos são inseridos em uma tabela em que cada elemento tem sua contribuição. Essas medidas são referentes à radiação-gama de Urânio, Tório e Potássio-40 emitidos pelas amostras, comparados com os picos de intensidades de cada elemento (U: 234, Th1: 286, Th2: 343 e K: 1460) presentes nas amostras. Com o passar dos anos há a queda natural dos elementos no solo e em todo o planeta. Os elementos radiativos são elementos presente na natureza a milhões de anos e com o passar dos anos estão diminuindo naturalmente. 
São considerados o tempo (t) em segundos (tempo que decorreu a análise das amostras) e a massa seca $(\mathbf{m})$ em gramas do material, além dos elementos já descritos.

Figura 4.2-4 - Exemplo da utilização dos valores obtidos pela dose anual

\begin{tabular}{|c|c|c|c|c|}
\hline \multicolumn{5}{|c|}{ Valores do Sedimento } \\
\hline$t=$ & 53651 & & & \\
\hline$m=$ & 59.710 & & & \\
\hline ct $T h=$ & 457 & & & \\
\hline ct Ur $1=$ & 296 & & & \\
\hline ct Ur $2=$ & 220 & & & \\
\hline ct $K=$ & 16 & & & \\
\hline Th & 5.724 & $+/-$ & 0.206 & ppm \\
\hline U & 2.969 & $+/-$ & 0.852 & ppm \\
\hline K & FALSO & $+/-$ & FALSO & $\%$ \\
\hline
\end{tabular}

Fornecido por: Laboratório de Vidros e Datação - FATEC/SP

Os valores obtidos por cada um dos elementos para os 4 testes estão abaixo:

Tabela 4.2-4 - Tabela com os dados dos elementos componentes da dose anual de todas as amostras.

\begin{tabular}{|c|c|c|c|c|c|c|}
\hline & Tempo (seg.) & Massa Seca (gr.) & Th & U1 & U2 & K \\
\hline P1 & 53651 & 59.710 & 457 & 296 & 220 & 16 \\
\hline P2 & 36542 & 46.690 & 308 & 199 & 162 & 8 \\
\hline P3A1 & 49366 & 65.430 & 260 & 190 & 131 & 16 \\
\hline P3A2 & 49864 & 38.344 & 353 & 220 & 178 & 19 \\
\hline
\end{tabular}

Elaborado por: Fernanda Volpon Neves 


\section{F) Dose Equivalente}

As amostras para serem trabalhadas no leitor RISO passaram por todo processo de limpeza já descrito acima (item 4.2.4.2.B). Após estar em posse do material limpo, foi iniciado todo o processo de medidas para elaborar a curva de calibração.

Com os resultados dos testes obtidos na Daybreak sobre a intensidade da luminescencia das amostras, foi possível estimar a dose que as amostras precisariam para a realização das medidas na RISO.

As doses estimadas para o trabalho das amostras são lançadas em planilhas (Figura 4.2-5) que fazem parte do Software RISO-Sequence Editor, cujo programa controlador faz o leitor RISO rodar as informações a partir desta planilha. Para cada amostra foram realizadas medidas de 15 alíquotas (Foto 4.2-19 e Foto 4.2-20).

Foto 4.2-19 - Disposição dos pratos na RISO

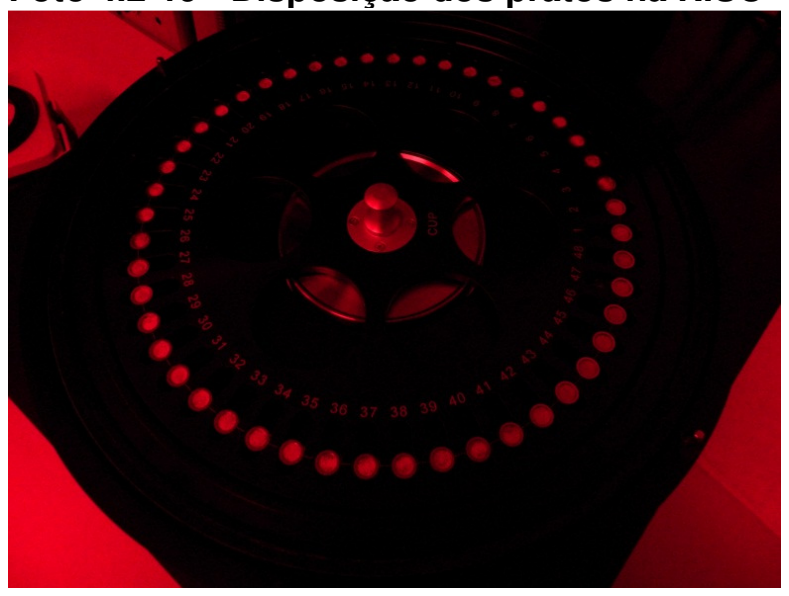

Fotografia de: Fernanda Volpon Neves, 2011
Foto 4.2-20 - Capacidade de 48 amostras

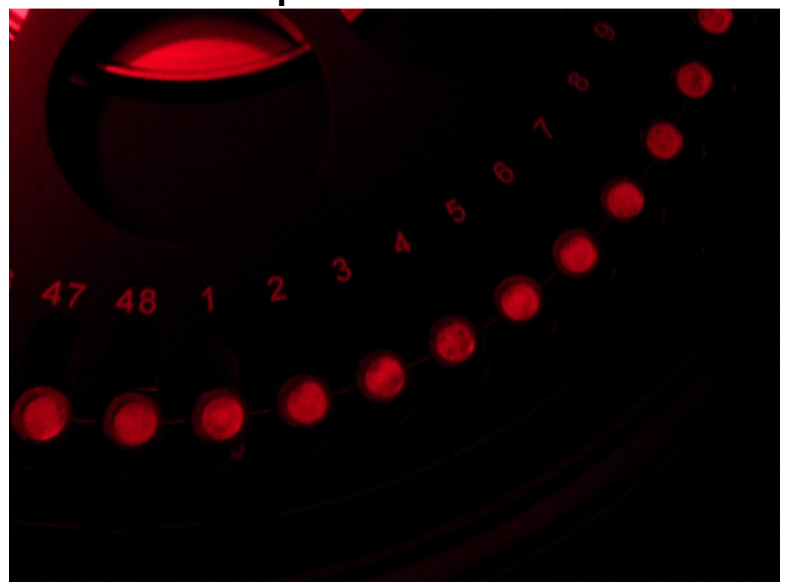

Fotografia de: Fernanda Volpon Neves, 2011

Se observar o destaque da planilha (Figura 4.2-5) ela é composta por várias colunas e linhas, sendo que nas linhas são as etapas da amostra, passando 
linha a linha antes de passar para a coluna ao lado. Isso significa que o primeiro teste da amostra $\mathrm{P} 1 \mathrm{~A} 1$ prato 1 foi realizado. Na sequência o prato 2, e assim sucessivamente, eliminando linha a linha até atingir o final do teste na coluna. Após as linhas serem processadas pelos 15 pratos, passa-se a próxima linha. No leitor RISO foi colocado dois filtros (U340) para garantir que não passaria nenhuma luz além da ultra-violeta em resposta à estimulação feita sobre a amostra.

Observe na planilha abaixo (Figura 4.2-5), nas linhas Set 5-7 os dados são os mesmos ao longo de todo o processo, isso significa que a amostra passa por uma dose teste, essa dose é padrão e faz parte do protocolo SAR que normaliza a amostra antes de passar por irradiação novamente.

Detalhando a Figura 4.2-5 as amostras passam pelo seguinte processo:

Sample é a quantidade de alíquotas da amostra, ou seja, foram colocados 15 pratos da amostra P1A1. Run 1 é a primeira coluna de medida sendo que cada prato passa sequencialmente por todas as linhas antes de mudar de coluna.

A linha Set 1 representa o tempo de irradiação em segundos que a amostra sofrerá, iniciando no caso destas amostras com 20s, chegando a 400s dependendo da amostra. Set 2 é o pré aquecimento que a amostra recebe a $260^{\circ} \mathrm{C}$, por 10s.

Set 3 é o tempo que a máquina fica recebendo a resposta da luminescência. Para o quartzo $40 \mathrm{~s}$ é suficiente para esvaziar a luminescência armazenada na amostra.

Set 5 é a dose teste da amostra, ou seja, sempre para cada teste de irradiação de cada coluna, todas as amostras passam pela normalização. A normalização é feita sempre com 35s (padronizado) para as amostras desta 
pesquisa, uma vez que significa $10 \%$ do valor da paleodose. O máximo das paleodoses das amostras foram de 400s.

Set 6 é o aquecimento da amostra, está indicado como TL mas é apenas para diferenciar o pré-aquecimento do Set 2 e não acarreta em troca de dados. Por fim o Set 7 que é novamente a medida LOE da amostra irradiada com a dose teste.

Após finalizar os testes em todas as colunas do Sequence Editor é necessário fazer testes para checagem da prova real da amostra. Esses testes de checagem são simples, para as amostras trabalhadas nesta pesquisa o padrão foi de 2 testes para cada amostra. Os valores de irradiação são iguais ao primeiro valor lançado para a amostra. No caso abaixo os testes foram refeitos com as irradiações de 20 s e 50 s correspondentes aos testes iniciais desta amostra. Os testes finais não servem para a calibração, mas devem ser feitos para verificar se a amostra atingiu seu ponto máximo de irradiação e de esvaziamento.

Figura 4.2-5 - Tabela extraída do Sequence Editor ${ }^{13}$

\begin{tabular}{|c|c|c|c|c|c|}
\hline \multicolumn{6}{|c|}{ File Edit Options Seq Control Help } \\
\hline 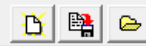 & 回 且 & 境回回 & $?$ & & \\
\hline & Samples & \multicolumn{2}{|l|}{ Run 1} & Run 2 & Run 3 \\
\hline Set 1 & $1-15$ & & Beta 20s & Beta 50s \\
\hline Set 2 & $1-15$ & \multicolumn{2}{|c|}{ Pre Heat $260^{\circ} \mathrm{C} ; 5^{\circ} \mathrm{C} / \mathrm{s} ; 10 \mathrm{~s}$} & Pre Heat $260^{\circ} \mathrm{C} ; 5^{\circ} \mathrm{C} / \mathrm{s} ; 10 \mathrm{~s}$ & Pre Heat $260^{\circ} \mathrm{C} ; 5^{\circ} \mathrm{C} / \mathrm{s} ; 10 \mathrm{~s}$ \\
\hline Set 3 & $1-15$ & \multicolumn{2}{|c|}{ OSL $125^{\circ} \mathrm{C}$ Blue LEDs; $40.00 \mathrm{~s} ; 5^{\circ} \mathrm{C} / \mathrm{s} ; 90.0 \%$} & OSL $125^{\circ} \mathrm{C}$ Blue LEDs;40.00s; $5^{\circ} \mathrm{C} / \mathrm{s} ; 90.0 \%$ & OSL $125^{\circ} \mathrm{C}$ Blue LEDs;40.00s; $5^{\circ} \mathrm{C} / \mathrm{s} ; 90.0 \%$ \\
\hline \multicolumn{6}{|l|}{ Set 4} \\
\hline Set 5 & $1-15$ & \multicolumn{2}{|l|}{ Beta 35s } & Beta 35s & Beta 35s \\
\hline Set 6 & $1-15$ & \multicolumn{2}{|c|}{ ITL $260^{\circ} \mathrm{C}, 5.00^{\circ} \mathrm{C} / \mathrm{s}, 250 \mathrm{Pts} ., \mathrm{PH}=0^{\circ} \mathrm{C}$ for $0 \mathrm{~s}$} & TL $260^{\circ} \mathrm{C}, 5.00^{\circ} \mathrm{C} / \mathrm{s}, 250 \mathrm{Pts} ., \mathrm{PH}=0^{\circ} \mathrm{C}$ for $0 \mathrm{~s}$ & IL $260^{\circ} \mathrm{C}, 5.00^{\circ} \mathrm{C} / \mathrm{s}, 250 \mathrm{Pts} ., \mathrm{PH}=0^{\circ} \mathrm{C}$ for $0 \mathrm{~s}$ \\
\hline Set 7 & $1-15$ & \multicolumn{2}{|c|}{ OSL $125^{\circ} \mathrm{C}$ Blue LEDs;40.00s; $5^{\circ} \mathrm{C} / \mathrm{s} ; 90.0 \%$} & OSL $125^{\circ} \mathrm{C}$ Blue LEDs;40.00s; $5^{\circ} \mathrm{C} / \mathrm{s} ; 90.0 \%$ & OSL $125^{\circ} \mathrm{C}$ Blue LEDs;40.00s; $5^{\circ} \mathrm{C} / \mathrm{s} ; 90.0 \%$ \\
\hline Set 8 & & & & & \\
\hline
\end{tabular}

Fonte: extraído das planilhas controladoras do leitor RISO.

O comportamento da alíquota gera um gráfico (Figura 4.2-6) com a resposta luminescente que estava acumulada e sua consequente liberação. Se considerar que a amostra tinha em seu estágio inicial o acúmulo da luminescência,

\footnotetext{
${ }^{13}$ Tabela necessária para rodar o sistema de software da máquina RISO
} 
em poucos segundos (para o caso da amostra abaixo) a amostra é esvaziada. $O$ tempo suficiente para atingir uma intensidade quase nula é de 40 s, como já informado ao valor padronizado para o quartzo.

Após a leitura das amostras o software gera uma curva que pode ser ajustada para uma curva exponencial ( $3^{\circ}$ gráfico da figura abaixo) referente à irradiação recebida na amostra e o comportamento de resposta da mesma. Esta curva é diretamente ligada à primeira curva referente à calibração da amostra descrita no $1^{0}$ gráfico da figura abaixo.

O gráfico que está na posição central da planilha (Figura 4.2-6) é resultado de todas as alíquotas que serão consideradas por amostra, no caso da amostra exemplificada abaixo P1A1 foram mantidas das 15 alíquotas, apenas 10. A exclusão das 5 alíquotas, foram decorrentes de não apresentarem comportamento satisfatório, o que comprometeria o todo da amostra.

Os valores considerados como referencial desta amostra estão descritos acima do gráfico central (Reference $=631.61$ segundos), que representam dentro do sigma de $2(+/-2)$ as respostas mais próximas do valor central da amostra. Quando os valores dentro do pontilhado (+/- 2) representam os valores esperados de resposta. Quanto mais pontos no interior do sigma, melhor o resultado da amostra.

Figura 4.2-6 - Informações extraídas do software RISO-Analyst para a amostra P1A1

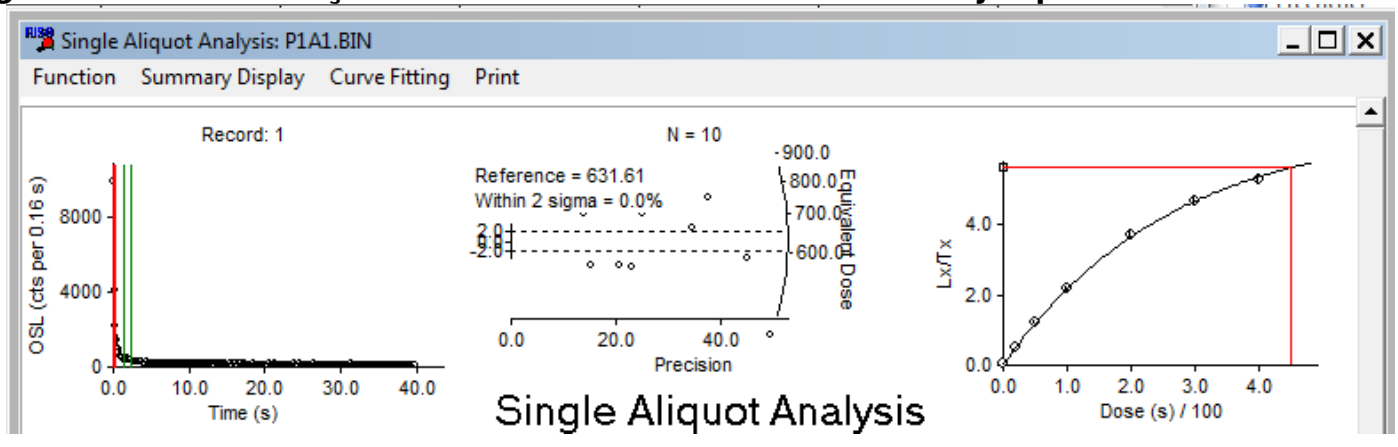

Fonte: Laboratório de Vidros e Datação - FATEC/SP 
Após obter os dados de referência de cada amostra, é preciso converter estes dados de segundos para Gray (Gy - paleodose), sendo que há novamente uma tabela padrão para utilização e conversão destes dados. Para as amostras P1A1/P1A2/P2A1/P2A2 obteve-se as seguintes paleodoses (

Tabela 4.2-5):

Tabela 4.2-5 - Conversão dos dados extraídos do leitor RISO em Gray, para cálculo da idade da amostra

\begin{tabular}{|c|c|c|} 
& $\begin{array}{c}\text { Dados de } \\
\text { Referência (seg.) }\end{array}$ & $\begin{array}{c}\text { Gray (Gy) } \\
\text { ou } \\
\text { Paleodose }\end{array}$ \\
\hline P1A1 & 631.61 & 56.3 \\
\hline P1A2 & 590.82 & 52.6 \\
\hline P2A1 & 313.04 & 27.9 \\
\hline P2A2 & 273.09 & 24.3 \\
\hline
\end{tabular}

Fonte: Adaptado de planilha fornecida pelo Laboratório de Vidros e Datação - FATEC/SP

Após a finalização da interpretação dos dados e convertidos os mesmos em paleodose é preciso inserir as informações em uma tabela, que, preenchendo apenas alguns dados, resultará na idade aproximada da amostra. 


\section{RESULTADOS E DISCUSSÕES}

Inicialmente neste capítulo será apresentada uma discussão entre o material coletado em campo com o que se encontrou na teoria sobre o momento e locais dos depósitos. $\mathrm{Na}$ sequência uma breve abordagem dos produtos cartográficos gerados com enfoque na evolução da captura fluvial, finalizando com as discussões acerca das datações, suas possibilidades e problemas.

\subsection{Produtos cartográficos}

\subsubsection{Carta Hipsométrica (ANEXO A)}

Esta carta hipsométrica ressalta os compartimentos presentes na área, variando de topo até a base cerca de 700 metros. Pode-se notar que a escarpa côncava com sua face voltada para o Litoral Paulista está bem pronunciada e dissecada principalmente no trecho leste da escarpa, onde a dissecação e o recuo estão mais intensos, com desenvolvimento de drenagem mais acentuada. Quando comparado ao modelo de evolução de relevo (Figura 3.1-1) de Oliveira (2003) podese fazer a relação de evolução do recuo de cabeceira nessa face leste da escarpa.

No trecho compreendido pelo planalto, ou reverso da Serra, há 2 compartimentos marcantes, sendo eles de 820 a 950 metros. $O$ trecho compreendido pela cor laranja é possível observar o encaixe do rio Guaratuba a leste da carta hipsométrica, além de maior quantidade de reentrâncias de drenagem neste patamar. 
Nos trechos mais altos observados de cor vinho $(950 \mathrm{~m}+)$ na carta hipsométrica é possível identificar um trecho entre os rios Claro e Guaratuba como um testemunho muito preservado, com poucos canais de drenagem e relevo pouco dissecado, quando comparado com as demais áreas abordadas.

\subsubsection{Carta de Declividade (ANEXO B)}

Nos trechos em que na carta hipsométrica são descritos como o planalto da Serra, ou reverso, as classes de declividade são predominantemente baixas (0 $18 \%$ ), ocorrendo alguns pequenos trechos com declividades acima de $46 \%$. O rio Claro no trecho a NE da carta de declividade apresenta um encaixe maior em sua margem direita se comparado com a margem esquerda, no entanto este entalhe não excede os $65 \%$ de declividade.

No rio Guaratuba é possível observar na carta que em boa parte de todo o seu trajeto compreendido pelo trecho apresentado nesta carta tem declividade muito baixa $(0-4 \%)$ apresentando uma boa área passível de inundação.

$\mathrm{Na}$ escarpa da serra predominam as classes de declividade elevadas, acima de $46-65 \%$, as declividades acima de $65 \%$ ocorrem em alguns pequenos trechos praticamente imperceptíveis. As declividades compreendidas de $0-12 \%$ marcam o contato do topo da serra com a escarpa. No sentido da base da escarpa as declividades são mais baixas sendo possível encontrar trechos compreendidos entre $12-18 \%$. 


\subsection{3. $\quad$ Carta de Orientação das Vertentes (ANEXO C)}

Nesta carta, pode-se observar que o tom cinza é considerado como plano, pertencente, quase sempre, a áreas de leitos de rio ou topos de morros. Notase na carta que há uma forte presença com faces orientadas em tons de rosa e verde comprovando a orientação NE-SW das cadeias de morros observados na carta hipsométrica e de compartimentação da vertente.

A escarpa da serra apresenta orientação predominante NE-SW e NW-SE em menor proporção, seguindo em direção ao rio Guaratuba.

Ao norte da carta há vertentes alongadas voltadas para NW (rosa), localizadas principalmente na margem esquerda do rio Claro, indicando os lineamentos e a estrutura evidente.

\subsection{4. $\quad$ Carta de Drenagem da área (ANEXO D)}

A carta de drenagem abrange uma área maior do que o quadrante da área de pesquisa, nela pode-se observar a presença marcante dos rios Claro e Guaratuba, além da Represa Ribeirão do Campo.

No planalto a drenagem está relacionada à presença de fraturas e lineamentos, seguindo o trajeto e angularidade média das estruturas condicionantes deste relevo, relacionada à tectônica. Essa angularidade é perceptível no $2^{\circ}$ compartimento, a leste da carta, onde se observa uma drenagem com formas bruscas, diferentemente da escarpa da serra, que apresenta drenagem mais longilínea, algumas nascendo no topo da escarpa, descendo até o Guaratuba por 
sulcos e entalhes na própria escarpa e buscando zonas mais friáveis para o desenvolvimento da mesma.

\subsubsection{Compartimentação do Relevo (ANEXO E)}

A carta de compartimentação do relevo apresenta os três patamares desenvolvidos para apoio a essa pesquisa, sendo: $1^{\circ}$ planalto - compartimento representado por todo o trecho ao norte da carta, com predomínio dos topos de morros e englobando a bacia do rio Claro; 2ำ planície fluvial do rio Guaratuba compartimenta todo o leito fluvial do rio Guaratuba incluindo praticamente todo o patamar da cota $820 \mathrm{~m}$; 3ำ borda e escarpa da Serra do Mar.

Nesta compartimentação o enfoque foi voltado para o rio Guaratuba e a partir dele às outras subdivisões, portanto, o compartimento gerado a partir do patamar do Guaratuba, um segundo compartimento acima e outro abaixo.

\subsection{Relação do material coletado com a evolução do relevo}

Foram obtidos em campo seis amostras de três pontos de coletas distintos (Quadro 5.2-1), todas as amostras foram utilizadas nas datações por LOE. As seis amostras foram coletadas com o intuito de realizar as primeiras datações. Posteriormente coletar-se-iam as demais amostras.

Como o tempo que cada amostra demanda é muito grande, optou-se por manter apenas as seis amostras iniciais, obtendo assim um panorama simplificado, como formato de ensaio da técnica para futuros desenvolvimentos da mesma. 
Quadro 5.2-1 - Pontos de Coleta de amostras para as datações.

\begin{tabular}{|c|c|c|}
\hline Nome Ponto & UTM X & UTM Y \\
\hline Amostra 1 - P1A1/ P1A2 & 408605 & 7382235 \\
\hline Amostra 2 - P2A1/ P2A2 & 408616 & 7382224 \\
\hline Amostra 3 - P3A1/ P3A2 & 407813 & 7382417 \\
\hline
\end{tabular}

Elaborado por: Fernanda Volpon Neves, 2012

As amostras coletadas faziam parte dos compartimentos de relevo elaborados a partir da carta de compartimentação, sendo que as amostras um e dois fazem parte do trecho compreendido pela borda do anfiteatro e a amostra três compreende o trecho no qual a influência maior são os afluentes do Guaratuba e o próprio rio Guaratuba, no local onde há o corredor que separa as drenagens do Guaratuba e rio Claro, atualmente um ponto considerado como divisor de águas.

No Planalto não foi possível coletar amostras para efeito de comparação, como já exemplificado, mas é possível observar curvas de nível atingindo 950 metros de altitude nos trechos leste e oeste do rio Claro. Estes morros formam conjuntos de topos convexos justapostos na direção NE-SW, tais como os próprios rios se posicionam. Diante deste posicionamento dos rios, obedecendo as estruturas das rochas e de acordo com o período em que houve mudanças climáticas do mesozóico-cenozóico, as influências residuais descritas por Modenesi-Gauttieri et al (2001) são factíveis de serem observadas de acordo com a posição que os rios adquiriram, sendo o entalhe dos canais posterior aos ajustes. A drenagem que acompanha a orientação principal dos rifts são dos rios Claro e Guaratuba, os afluentes nem sempre são concordantes a exemplo deste abaixo (Foto 5.2-1 e Foto 5.2-2), em que a água corre transversal ao bandamento. 
Foto 5.2-1 - Afluente do Guaratuba

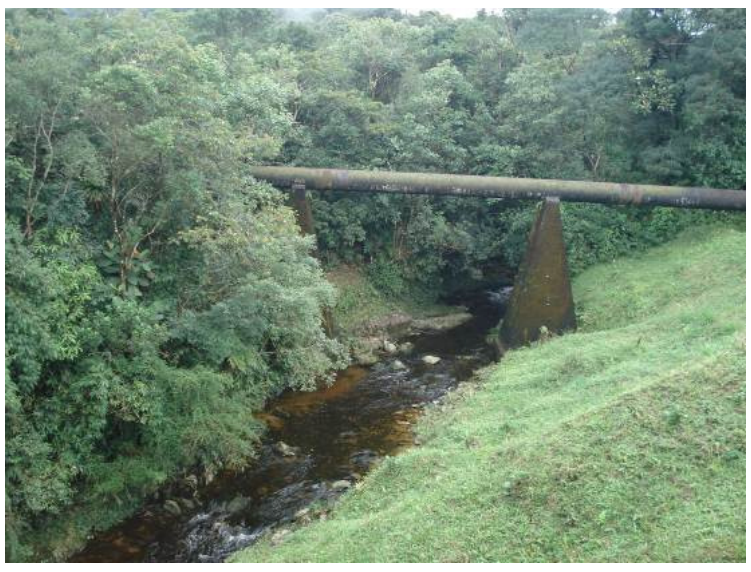

Fotografia de: Fernanda Volpon Neves, 2011 UTM: 408309/ 7382256
Foto 5.2-2 - Bandamento no fundo do rio, transversal a drenagem

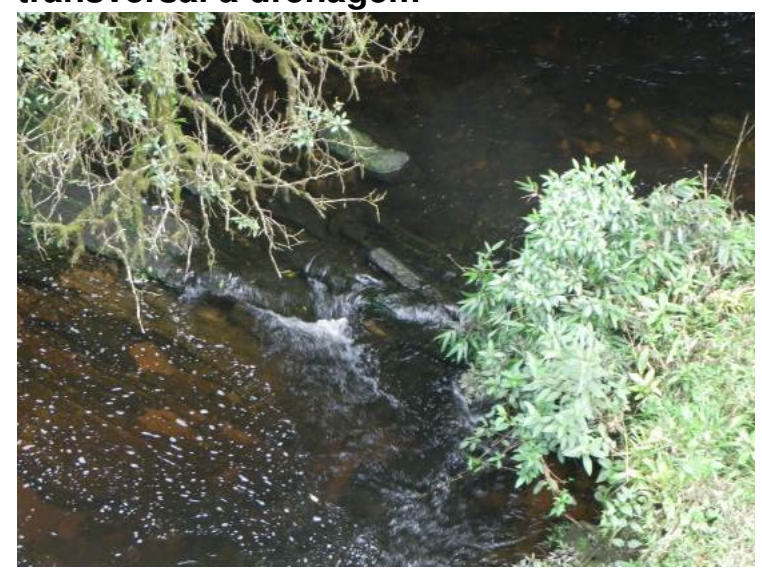

Fotografia de: Déborah de Oliveira, 2011 UTM: 408309/ 7382256

Ainda considerando as mudanças climáticas como forte relação com os depósitos e entalhe da drenagem, tal como os ajustes de drenagem e de relevo local decorrente dos últimos movimentos tectônicos, é possível identificar pontos como este da foto abaixo, que comprova de forma clara as diferenças de momentos de deposição uma vez que há dois ambientes distintos de deposição, caracterizados por este contato litológico e pedológico, cuja transição de Espodossolo para Gleissolo é bem marcante (Foto 5.2-3). Ao longo de todo o barranco encontrado neste local de separação das drenagens local é possível encontrar cascalheiras e depósitos de sedimentos dos mais diversos (Foto 5.2-4). 
Foto 5.2-3 - Transição de Espodossolo
para Gleissolo.

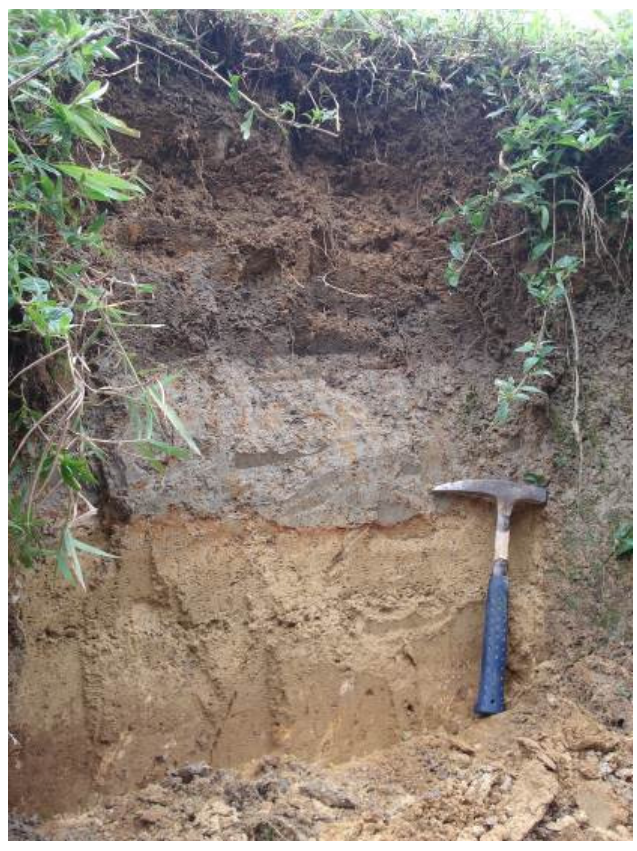

Fotografia de: Fernanda Volpon Neves, 2011.

UTM: 408193/ 7382297

\section{Foto 5.2-4 - Cascalheira presente nos barrancos}

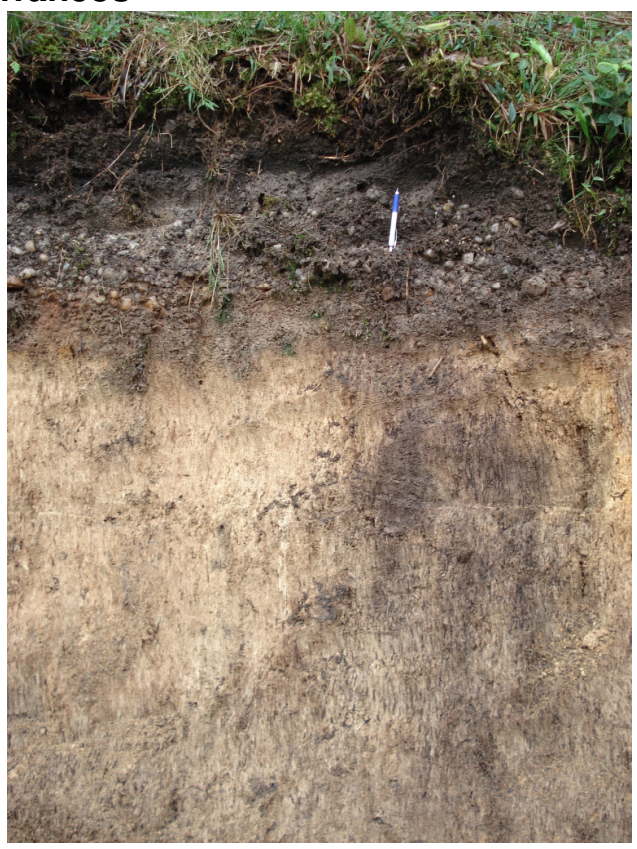

\section{1}

UTM: 408193/ 7382297

Ao longo do rio Guaratuba a planície é mais larga se estreitando quando chega próximo ao cotovelo de captura, que se apresenta mais encaixado com presença de matacões e rochas expostas concordantes com a direção da estrutura das camadas NE-SW (Foto 5.2-5). No trecho da escarpa da serra o rio torna-se mais estreito devido ao entalhe que o mesmo está provocando através do recuo de cabeceira. Nas declividades mais acentuadas o rio Guaratuba tende a ser mais estreito, no entanto ao alcançar declividades mais amenas o rio alarga-se novamente, apresentando uma foz extensa (Foto 5.2-6). 
Foto 5.2-5 - Orientação das rochas NE-SW, Guaratuba correndo oblíquo às estruturas.

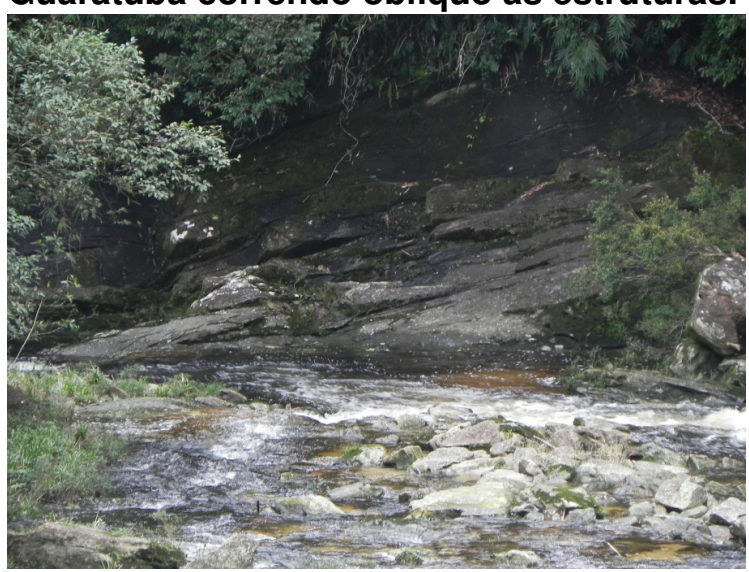

Fotografia de: Déborah de Oliveira, 2011 UTM: $408597 / 7382312$
Foto 5.2-6 - Foz do rio Guaratuba.

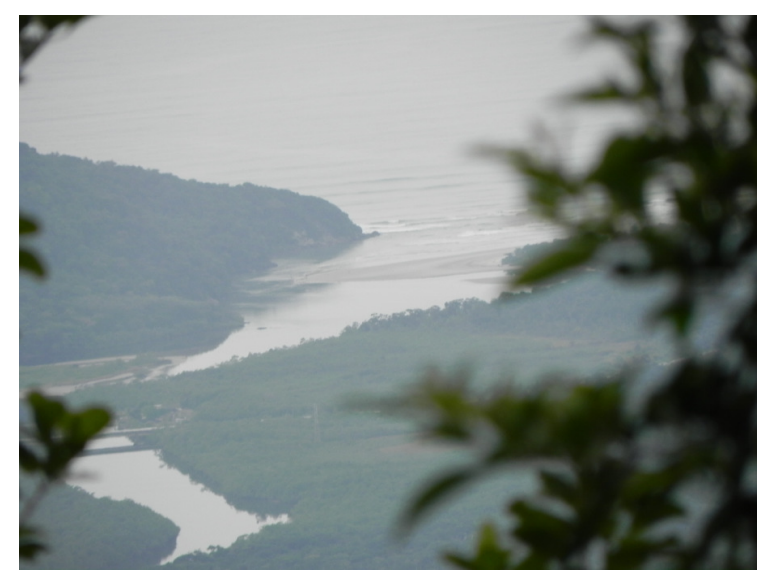

Fotografia de: Déborah de Oliveira, 2011

A estação de captação de água está localizada próximo ao limite entre a planície do Guaratuba e a escarpa da serra. A estrada (Foto 5.2-7) que leva até a captação de água (Foto 5.2-8) do rio Guaratuba acompanha o corredor existente entre os rios Claro e Guaratuba, entre as vertentes alongadas e as altitudes elevadas dos topos convexos. Neste local, por uma divisão de compartimentos, pode-se apontar como sendo o local onde, por algum momento o rio Guaratuba possa ter percolado, uma vez que os depósitos descritos estão orientados e depositados ao longo de um grande trecho desta estrada de acesso. 
Foto 5.2-7 - Estrada de acesso à Casa de captação de água.

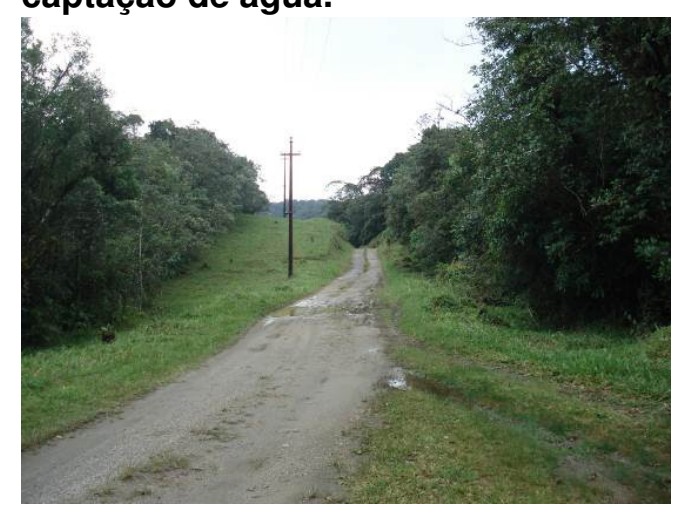

Fotografia de: Fernanda Volpon Neves, 2011. UTM: $408597 / 7382312$
Foto 5.2-8 - Casa da captação da água.

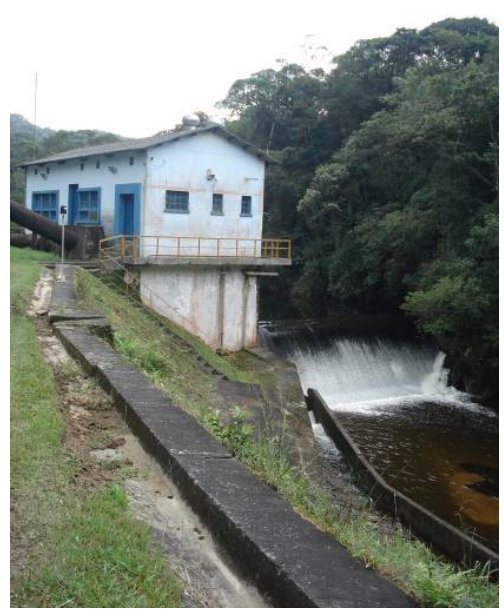

Fotografia de: Fernanda Volpon Neves, 2011.

UTM: $408597 / 7382312$

A escarpa da serra descrita como o $3^{\circ}$ nível na carta de compartimentação aparece classificada com níveis de 170 - 690 m, com equidistância das curvas de $10 \mathrm{~m}$. Não foram englobadas na pesquisa as partes abaixo das curvas de 170 metros, por fazerem parte do sopé da serra e início da planície costeira. A escarpa apresenta as curvas de níveis muito próximas, caracterizando um relevo íngreme. Sua vertente é côncava com feições mais íngremes em seu topo, se comparado aos baixos níveis da escarpa onde apresentam declividades mais amenas. A escarpa tem seus rios alongados, afluentes do Guaratuba, com características de drenagem dendrítica em praticamente todo o trecho da bacia. 


\subsection{Datação: possibilidades e problemas}

As amostras coletadas conforme descritas acima foram seis, sendo coletadas em trechos pertencentes a compartimentação elaborada da área. As amostras foram trabalhadas em laboratório obedecendo todos os procedimentos exigidos de limpeza e de datação utilizando o protocolo de amostra da alíquota única (SAR) conforme supracitado (4.2.4.2).

Após o desenvolvimento de toda a técnica e correções necessárias nas amostras obtivemos os seguintes resultados:

Tabela 5.3-1 - Idade das amostras realizadas em LOE.

\begin{tabular}{|c|c|c|}
\hline Ponto de Coleta & Amostra & Idade (mil anos) \\
\hline \multirow{2}{*}{ Coleta 1 } & P1A1 & $29+/-5$ \\
\hline \multirow{2}{*}{ Coleta 2 } & P1A2 & $27+/-5$ \\
\hline \multirow{2}{*}{ Coleta 3 } & P2A1 & $12+/-1$ \\
\hline & P2A2 & $10+/-1$ \\
\hline & P3A1 & - \\
\hline
\end{tabular}

Fonte: Elaborado por: Fernanda Volpon Neves, 2012

Como é possível observar nas amostras dos pontos de coleta um e dois, os resultados estão muito semelhantes em cada dupla de amostra, no entanto para as amostras do ponto três não se obteve resultados possíveis de gerarem idades relativas das amostras. O não resultado das amostras do ponto de coleta 3 pode advir de diversos fatores, dentre eles: rocha alterada in situ (impossível de datar), umidade da amostra, percolação de material de camada mais superiores até a camada em questão, dentre outros descritos adiante. 
A datação foi o instrumento escolhido para apresentar as idades relativas das amostras com o intuito de se comprovar a idade aproximada em que possa ter ocorrido o desvio do rio Guaratuba, acarretando na captura fluvial.

Para que esse fenômeno tenha ocorrido, estima-se que as idades variem entre o final do Mesozóico (Cretácio) ao Cenozóico, alcançando o Pleistoceno como citado por diversos autores (Modenesi-Gauttier, 2001; De Martonne, 1943; Almeida \& Carneiro, 1998). Se considerar que esses períodos geológicos têm idades variando de $+/-10$ mil anos à $+/-146$ milhões de anos, as idades encontradas pelas amostras estariam dentro do período teoricamente estabelecido.

Diante das idades apresentadas acredita-se estar pesquisando pela linha correta das informações, no entanto as amostras pela posição em relação à vertente estão com seus resultados invertidos, ou seja, as amostras mais baixas (P1A1 e P1A2) deveriam ser as mais recentes, neste caso a diferença entre as amostras dos pontos um e dois são próximas, mas divididas por um degrau de terraço.

Não se sabe ao certo o que pode ter provocado essa inversão de idades. Pode ser que as amostras tenham sido parte de um mesmo terraço, mas que atualmente os pontos das amostras P1A1 e P1A2 estejam sofrendo retrabalhamento de material, ou até mesmo seja área fonte de material. Não é possível comprovar a evolução ao nível de detalhe de áreas tão próximas, mas a relação entre elas tanto de tipo de material quanto do comportamento das idades é muito semelhante.

Se considerar que as amostras de P1 estão com idades mais antigas em relação às amostras de P2, e considerar que elas estão corretas desta forma, informar-se-á que as mesmas são originárias de uma mesma área, e que as amostras de P1 foram exumadas, por isso as idades estão invertidas. 
Essas possibilidades estão sendo apresentadas uma vez que não se descarta a possibilidade das datações estarem corretas, apenas não estão concordantes com o que se previa. Encará-las como amostras que não deram resultado seria mais prático, uma vez que não haveria necessidade de discutir acerca do que poderia estar ocorrendo na área.

Não é possível comprovar nenhuma dessas possibilidades no momento, só se sabe que as amostras foram coletadas em locais muito úmidos, o que pode ter acarretado numa distorção das informações, ou até mesmo mistura de material transportado através de percolação da água de superfície para dentro do compartimento de solo.

As amostras que dariam um melhor resultado seriam as amostras do ponto de coleta 3 (P3A1 e P3A2). Estas amostras por algum motivo desconhecido não deram nenhum resultado passível de cálculo. Se observar o gráfico abaixo e compará-lo com a figura (Figura 5.3-1) apresentada anteriormente é possível uma comparação do comportamento das doses. Observando-se que não é possível gerar a curva de calibração individual das amostras do ponto de coleta três, o quartzo não teve o comportamento esperado. Isso decorre no comportamento das amostras que não foi o esperando. Sendo assim, não é possível extrair o valor de referência em segundos para se obter a paleodose e, consequentemente, a obtenção da idade aproximada da amostra. 
Figura 5.3-1 - Gráfico dos dados da amostra P3A2
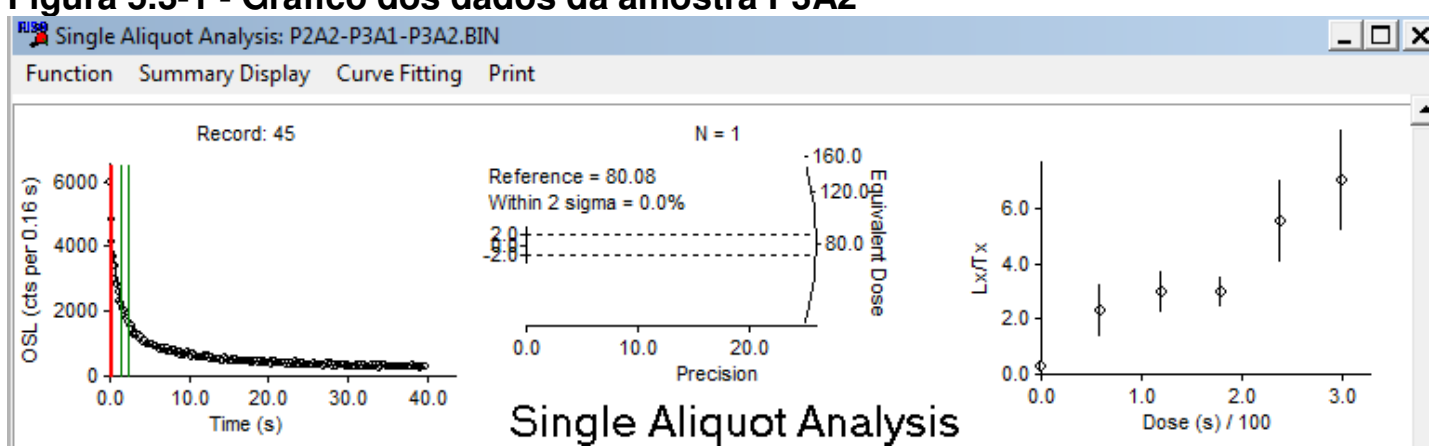

Fonte: Laboratório de Vidros e Datação - FATEC/SP

As amostras P3A1 / P3A2, seriam importantes por terem sido coletadas no ponto onde se tem as informações mais importantes sobre a evolução do relevo (trecho de separação dos rios Claro e Guaratuba) e os processos de deposição de material já apresentados. A datação deste pacote não deu resultado e as possibilidades para que isso tenha ocorrido são inúmeras, sendo elas: material muito úmido por conta de percolação de água; coleta de material alterado de rocha (P3A2); fluxo de água intenso da superfície para o interior do pacote de solo, provocando mistura de quartzo de diferentes momentos de deposição; contaminação da amostra em laboratório; dentre outros tantos problemas. 


\section{CONSIDERAÇÕES FINAIS}

Compreender a evolução do cotovelo de captura do rio Guaratuba, assim como as relações existentes no local foi determinante para a compartimentação que se fez da área, considerando o relevo e a drenagem local como determinantes nesta compartimentação.

A captura fluvial, já havia sido descrita por Rossi (1999) e Oliveira (2003), no entanto o diferencial deste trabalho foi justamente a compreensão deste cotovelo de captura, vinculando-a ao período em que as drenagens possam ter sido ajustadas. Acredita-se desse modo, que a datação passa a ser determinante, uma vez que pôde informar o período geológico ao qual a evolução da drenagem está atrelada.

Os compartimentos identificados foram: I: Planalto; II: Planície fluvial do rio Guaratuba; III: Borda da escarpa e escarpa da Serra. A partir destes compartimentos foi possível coletar as amostras de campo para as datações que se seguiram.

Os resultados obtidos através da datação foram satisfatórios, considerando-se que tenha sido possível discutir as idades correlacionando-as com as idades aproximadas descritas por outros autores sobre a evolução da Serra do Mar. Embora somente seis amostras datadas não possam refletir o comportamento da área como um todo, não deixa de ser um estímulo para que outras pesquisas acerca da evolução do cotovelo de captura sejam desenvolvidas.

A técnica de datação por LOE no leitor RISO demandou muitas horas de dedicação e prática no manuseio das amostras e equipamentos, desde a preparação do material até a obtenção dos resultados, entretanto o trabalho foi 
muito interessante principalmente pelo desafio que o mesmo proporcionou e a gratificação da aquisição de novos conhecimentos.

De acordo com os resultados obtidos nesta pesquisa, sugere-se o estudo através da datação para as demais áreas da pesquisa a fim de compreender a evolução que a drenagem do Guaratuba passou. Sugere-se ainda o estudo detalhado dos rifts e falhamentos a ENE da escarpa da serra, à montante do rio Guaratuba, assim como sua morfometria a fim de elucidar de forma mais completa a possível evolução da drenagem do Guaratuba. 


\section{REFERÊNCIAS}

AB'SABER, A. N. Sucessão de quadros paleogeográficos no Brasil do triássico ao quaternário. Anuário da Faculdade de Filosofia, PUC, Sedes Sapientiae, São Paulo, p.61 - 69, 1950-1951.

AB'SABER, A. N. Aspectos Geográficos da Terra Bandeirante. Revista do Instituto Brasileiro de Geografia e Estatística. Serviço Gráfico do IBGE, Rio de Janeiro, p.1-97, 1954.

AB'SABER, A. N. O problema das conexões antigas e da separação da drenagem do Paraíba e do Tietê. Boletim Paulista de Geografia - SP. № 26, p. 38 49, 1957.

AB'SABER, A. N. O domínio dos Mares de Morros no Brasil. São Paulo, SP. Instituto de Geografia da Universidade de São Paulo. Revista Geomorfologia, no 2. 1966. Não paginado.

AB'SABER, A. N. Um conceito de Geomorfologia a serviço das pesquisas sobre o Quaternário. Geomorfologia. 18, IGEOG-USP. São Paulo, p. 1 -23, 1969.

AB'SABER, A. N. Ritmo da Epirogênese pós-cretácica e setores das superfícies neogênicas em São Paulo. Geomorfologia. 13, Instituto de Geografia USP. São Paulo, p. 1 - 19, 1969.

ALMEIDA, F.F.M de \& CARNEIRO, C.D.R. Origem e evolução da Serra do Mar. Revista Brasileira de Geociências. 28(2), p. 135 - 150, 1998.

BIGARELLA, J.J., BECKER, R. D., SANTOS, G. F. dos, PASSOS, E., SUGUIO, K., Estrutura e origem das paisagens tropicais e subtropicais. Florianópolis - SC. Editora UFSC, 1994. 
BIGARELLA, J.J., MOUSINHO, M.R., Significado paleogeográfico e paleoclimático dos depósitos rudáceos. Boletim Paranaense de Geografia, № 16 e 17, p. $7-17,1965$.

BIGARELLA, J.J., MOUSINHO, M.R., SILVA, J. X. Considerações a respeito da evolução das vertentes. Boletim Paranaense de Geografia, ํo 16 e 17, p. $85-117,1965$.

BIGARELLA, J. J. ,MOUSINHO, M. R., SILVA, J. X. Pediplanos, pedimentos e seus depósitos correlativos no Brasil. Boletim Paranaense de Geografia, ํo 16 e 17, p. $117-153,1965$.

BIGARELLA, J. J. MOUSINHO, M. R. Considerações a respeito dos terraços fluviais, rampas de colúvio e várzeas. Boletim Paranaense de Geografia, no 16 e 17, p. $153-195,1965$.

CARNEIRO, C.D.R. MIZUSAKI, A.M.P. ALMEIDA.F.F.M. A determinação da idade das rochas. Terrae Didática 1 (1): 6-35, 2005. $<$ <ttp://www.ige.unicamp.br/terraedidatica/>

CASSETI, V. Elementos de geomorfologia. Editora contexto, 1994.

CHRISTOFOLETTI, A. Capturas fluviais. In: Enciclopédia Mirador Internacional. São Paulo, vol.5, p. 2049 - 2051, 1975.

CHRISTOFOLETTI, A . Considerações sobre o nível de base, rupturas de declive, capturas fluviais e morfogênese do perfil longitudinal. Revista Geografia 2 (4) : 81-102, outubro 1977.

CHRISTOFOLETTI, A . Geomorfologia. 2ํed. , SP, Edgard Blucher. 1980.

CHRISTOFOLETTI, A. Geomorfologia Fluvial, V.1 O Canal Fluvial. Edgard Blucher. 1981. 
COELHO NETTO, A. L. Evolução de Cabeceiras de Drenagem no Médio Vale do Rio Paraíba do Sul (SP/RJ): a Formação e o Crescimento da Rede de Canais sob Controle Estrutural. In: Revista Brasileira de Geomorfologia, Ano 4, oo2, p.69-100, 2003.

CONTI, J.B. FURLAN, S.A. Geoecologia: O Clima, os Solos e a Biota. In: Geografia do Brasil. 5ำed. revisada e ampliada. São Paulo: Editora da Universidade de São Paulo. ROSS (Org), J.L.S. 2005.

CUNHA, P. P. A importância da datação por luminescência em estudos de Geomorfologia e de Geologia do Quarternário. In: V Congresso Nacional de Geomorfologia, 2010, Porto. Anais do V Congresso Nacional de Geomorfologia. Porto, 2010. Não paginado.

DAVIS, W. M. La Seine, la Meuse et la Moselle. Annales de Géographie. Paris. Armand Colin et Cie, Editeurs. p. 25-48. 1895. Traduzido por: Déborah de Oliveira. O Sena, o Mosa e o Mosela. Revista Confins, ํo 4, 2008.

DAVIS, W. M. The Geographical Cycle. The Geographical Journal, vol. 14. oㅜ 5, p. 481-504, 1899.

DE MARTONNE, E. Problemas morfológicos do Brasil Tropical Atlântico. Revista Brasileira de Geografia. Ano V, no 4, p. 3-30; Ano VI, no 2, p.3-26. São Paulo. SP. 1943/1944.

DULLER, G.A.T. Luminescence dating of Quaternary sediments: recent advances. In: Journal of Quaternary Science, 19(2), p 183-192, 2004.

FOLZ, E., PIERRE, B., BONTE P., JORON, JL., MERCIER, N., REYSS, JL. OSL dating of fluvial quartz from Le Closeau, a Late Paleolithic site near Paris comparison with $14 C$ chronology. In: journal of Quaternary Science Reviews, p. 927933, 2001. 
GUERRA, A.J.T. \& CUNHA, S.B. Geomorfologia: uma atualização de bases e conceitos. Rio de Janeiro, Bertrand Brasil. Capítulos 3: COELHO NETO. A.L. Hidrologia de encosta na interface com a Geomorfologia. Capítulo 4: GUERRA. A.J.T. Processos erosivos nas encostas, 2007.

IGC. Bases Cartográfica do IGC (Instituto Geográfico e Cartográfico) 1988, Escala 1:10.000. Folhas de Serra Guaratuba e Fazenda Florestal do Rio Grande. Equidistância das Curvas de 10 metros.

INMET, Instituto Nacional de Meteorologia. Normais Climatológicas do Brasil - 1961 a 1990. Sitio do INMET, Brasília, 1992. http://www.inmet.gov.br/html/clima.php

KING, L. C. A Geomorfologia do Brasil Oriental. Revista Brasileira de Geografia, Ano XVIII, № 2, p. 3 - 121. 1956.

MABBUTT, J.A. Landforms of the Western Macdonnel Ranges: A study of inheritance and periodicity in the geomorphology of arid central Australia. Essays in Geomorphology, DURY, G.H (Org.). American Elsevier Publishing Company, 1966.

MARTINS, A. A. \& CUNHA, P. P. Vantagens e limitações da luminescência opticamente estimulada na datação de terraços do rio Tejo, sua importância na determinação da taxa de incisão fluvial. VII Congresso Nacional de Geologia, Univ. Évora. Portugal, 2006.

MIYAMOTO, M. Estudo e aplicação da dosimetria termoluminescente na datação. (Tese de Doutorado). Instituto de Física da USP, Departamento de Energia Atômica, São Paulo - SP, 1973.

MODENESI-GAUTTIERI, M.C. HIRUMA, S.T. \& RICCOMINI, C. Morphotectonics of a high plateau on the northwestern flank of the Continental Rift of Southeastern Brazil. Geomorphology, 43, p. 257-271, 2001. 
MURRAY, A.S. WINTLE, A.G. The single aliquot dose protocol: potential for improvements in reliability. Radiation Measurements, 37. p. $377-381,2003$.

NEVES, F. V. OLIVEIRA, D. de. Caracterização da análise morfológica da evolução da captura de drenagem do rio Guaratuba no relevo da Serra do MarBoracéia SP, In: VIII Simpósio Nacional de Geomorfologia, 2010, Recife. Anais do VIII Simpósio Nacional de Geomorfologia. Recife: Editora da UFPE, 2010.

OLIVEIRA, D. de. A captura do Alto Rio Guaratuba: uma proposta metodológica para o estudo da evolução do relevo na Serra do Mar, Boracéia - SP. (Tese de Doutorado). FFLCH, Departamento de Geografia, USP, São Paulo - SP, 2003.

OLIVEIRA, D. de; SILVA, K. de S.; SANTOS, A. H. B. dos; PASA, V. NEVES, F. V. Anomalias de drenagem no Planalto Atlântico Paulista (Brasil) e evidências de capturas de drenagem. In: V Congresso Nacional de Geomorfologia, 2010, Porto. Anais do V Congresso Nacional de Geomorfologia. Porto, 2010.

RICOMINNI, C. et al. Tectônica e sedimentação no sistema de rifts continentais da serra do mar (Bacias de Volta Redonda, Resende, Taubaté e São Paulo). Anais do primeiro simpósio de Geologia, RJ-ES, SBG, 1987.

ROSSI, M. Fatores formadores da Paisagem Litorânea: A Bacia do Guaratuba, São Paulo - Brasil (Tese de Doutorado) FFLCH, Departamento de Geografia, USP, São Paulo - SP 1999.

SALVADOR, E.D. RICCOMINI, C. Neotectônica da região do Alto Estrutural de Queluz (SP-RJ, Brasil). Revista Brasileira de Geociências, 25, p.151164, 1995. 
SANTOS, R. D. dos; LEMOS, R.C.de; SANTOS, H.G.dos; KER, J.C.; ANJOS, L.H.C.dos. Manual de descrição e coleta de solo no campo. 5ª ed. revista e ampliada. Viçosa, Sociedade Brasileira de Ciência de Solo, 2005.

SCHUMM, S. A. The fluvial System. Department of Earth Resources, A Wiley-Interscience Publication, p.234-243, 1977.

SUGUIO, K. Geologia Sedimentar. São Paulo. Editora Blucher, 2003.

SUGUIO, K. \& BIGARELLA, J. J. Ambiente Fluvial. $2^{2}$ edição. Florianópolis; Editora da UFSC (Editora da Universidade Federal do Paraná), Florianópolis, Paraná, 183 p., 1990.

TEIXEIRA, W (Org.). Decifrando a Terra. Oficina de Textos, 2000. Capítulo 9: GIANNINI, P.C.F. \& RICOMINNI, C. Sedimentos e Processos Sedimentares.

WAShBURne, C. W. Geologia do Petróleo do Estado de São Paulo. Traduzido do original por PACHECO, J. Petroleum Geology of the State of São Paulo - Brasil. Oficinas Gráficas do Serviço de Publicidade Agrícola, Rio de Janeiro, RJ. 1939.

Von ENGELN, O.D. Geomorphology - Systematic and Regional. The Macmillan Company, New York. 1942.

WALLINGA, J. MURRAY, A. WINTLE, A. The single-aliquot regenerativedose (SAR) protocol applied to coarse-grain feldspar. Radiation Measurements. 32, p. $529-533,2000$. 


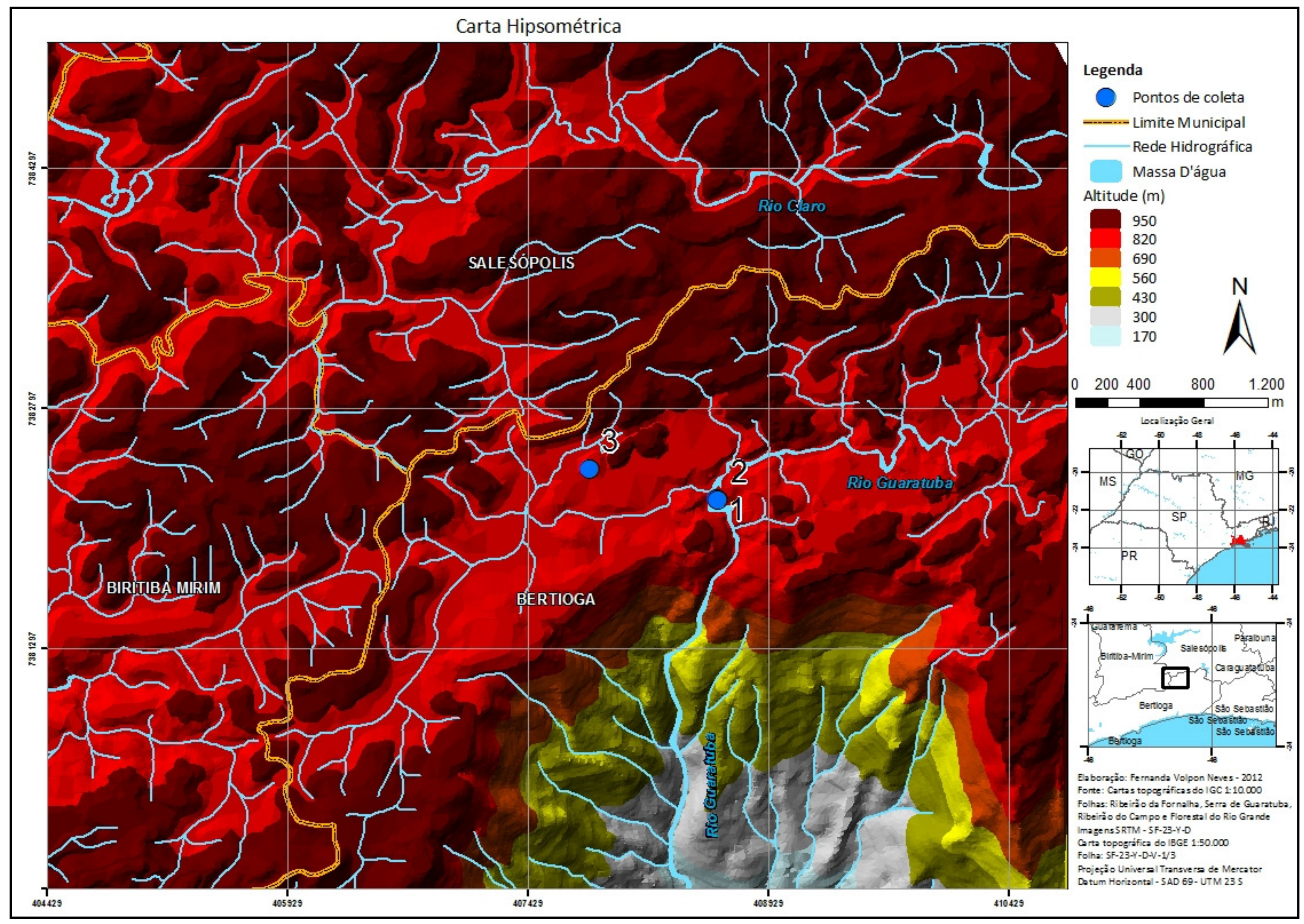




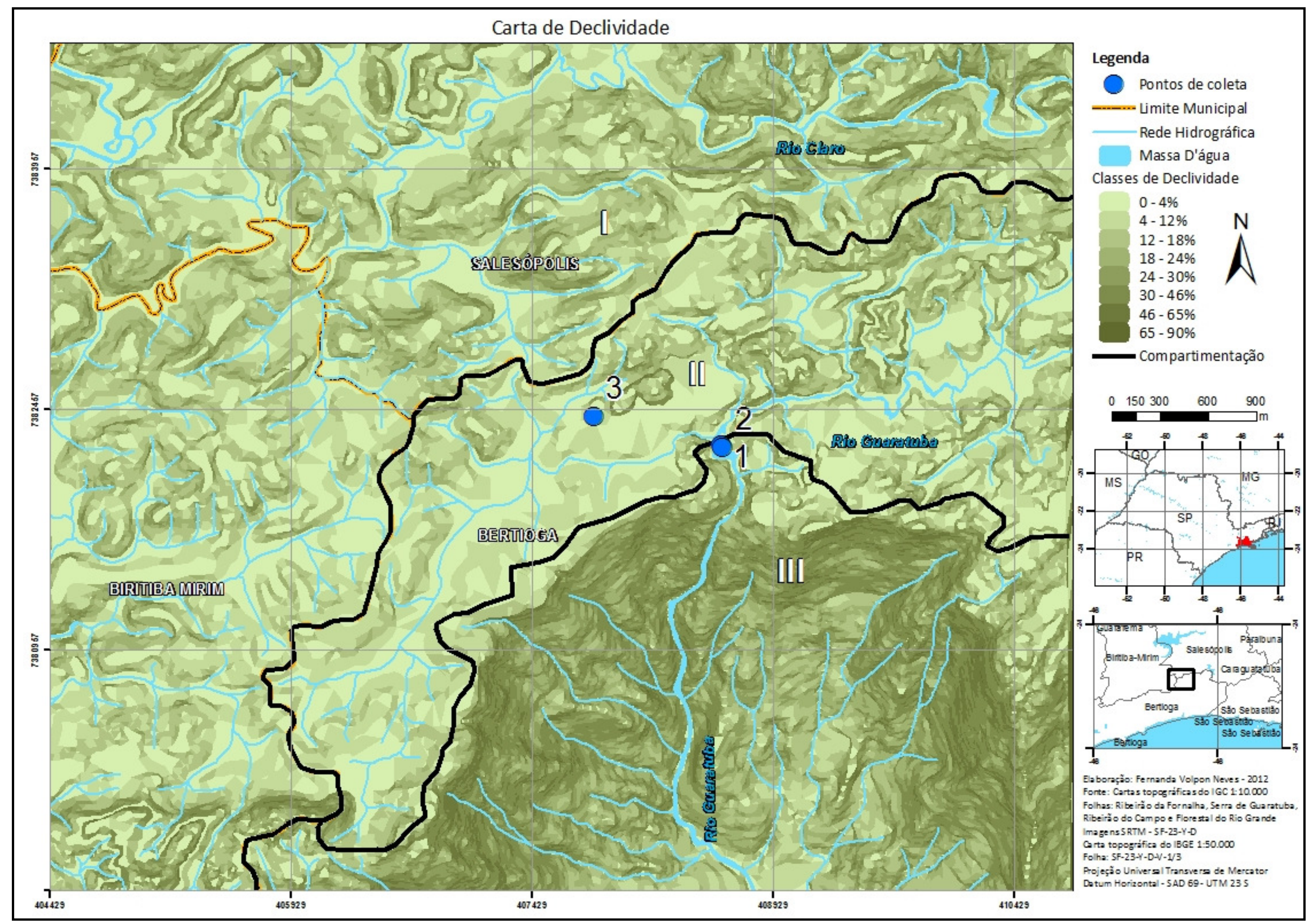




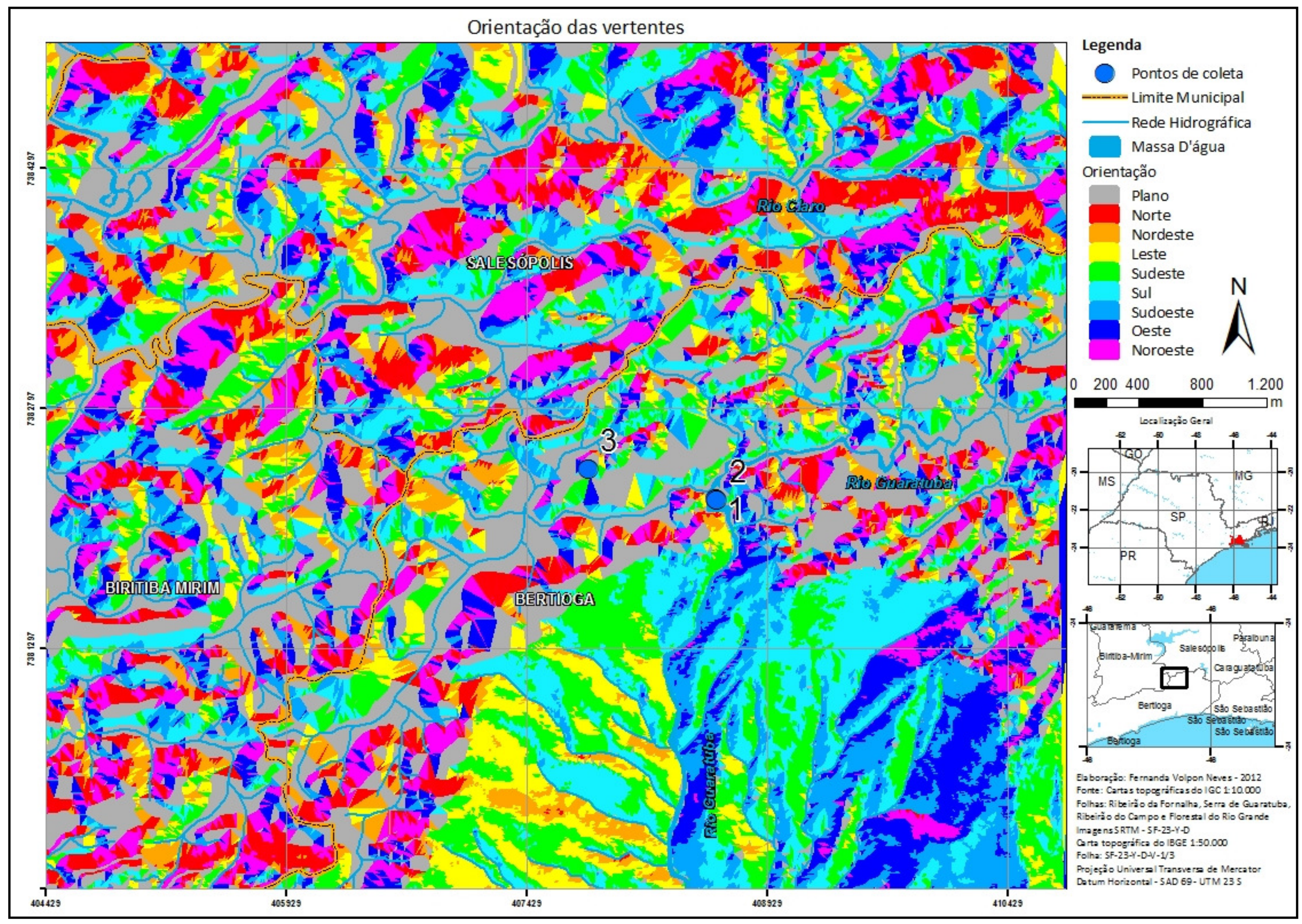




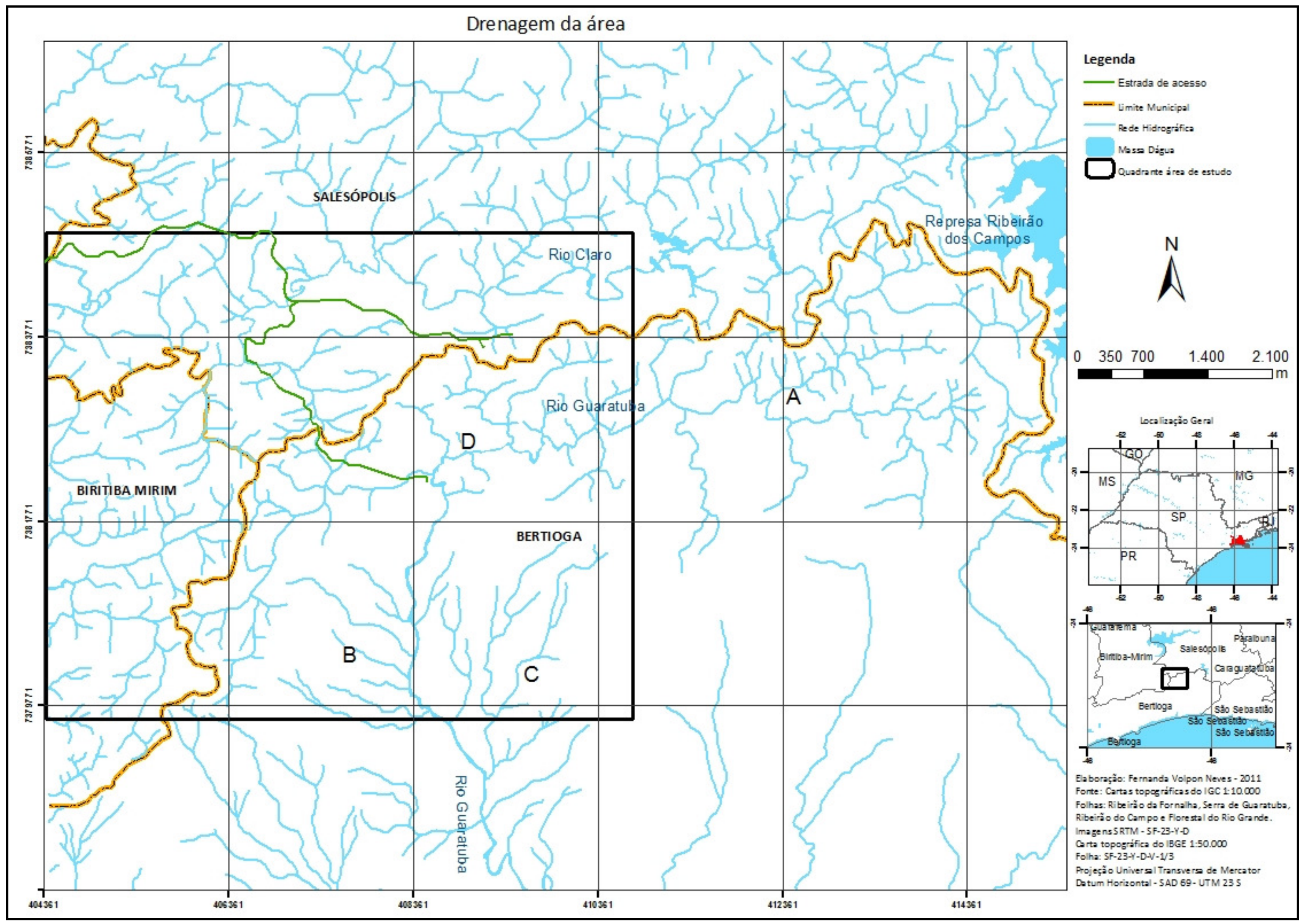




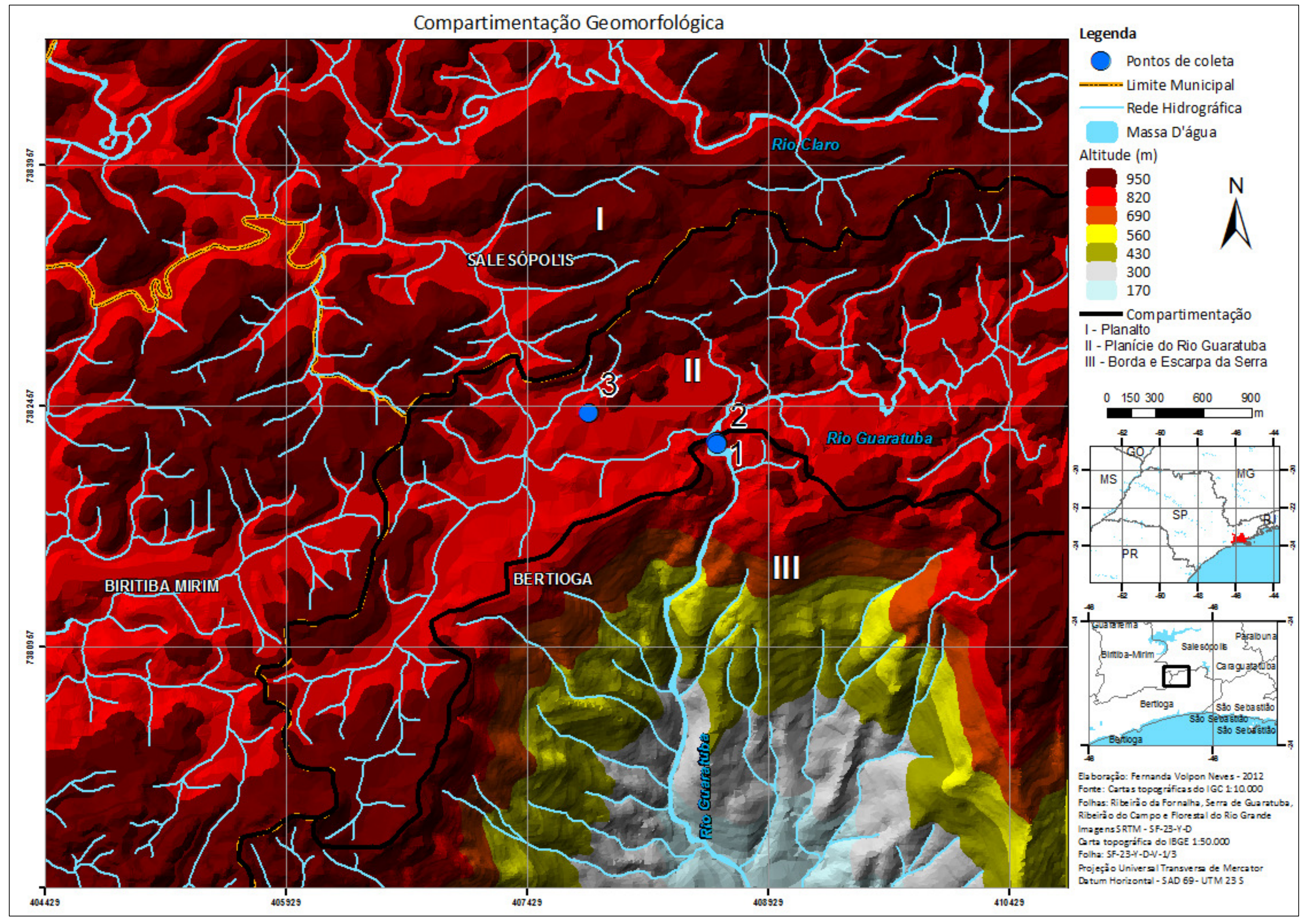


